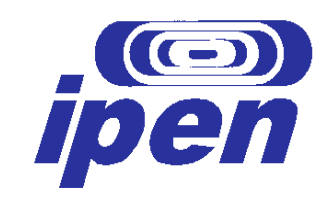

INSTITUTO DE PESQUISAS ENERGÉTICAS E NUCLEARES Autarquia Associada à Universidade de São Paulo

\title{
PREPARAÇÃO E CARACTERIZAÇÃO DE ELETROCATALISADORES PtRu/C E PtSn/C VIA REDUÇÃO QUÍMICA POR ÁCIDO CÍTRICO PARA OXIDAÇÃO DIRETA DE ALCOÓIS EM CÉLULAS A COMBUSTÍVEL TIPO PEM.
}

ROBERTO WILLYAN RAMON VERJULIO DA SILVA

\begin{abstract}
Dissertação apresentada como parte dos requisitos para obtenção do Grau de Mestre em Ciências na Área de Tecnologia Nuclear - Materiais.
\end{abstract}

Orientador:

Dr. Almir Oliveira Neto 


\section{DEDICATÓRIA}

À minha super Mãe Helaine À minha querida irmã Sylmara Ramon Ao meu pai José Roberto e toda minha Família. (Em memória de Alaide Ramon e Maria Firmino) 
9
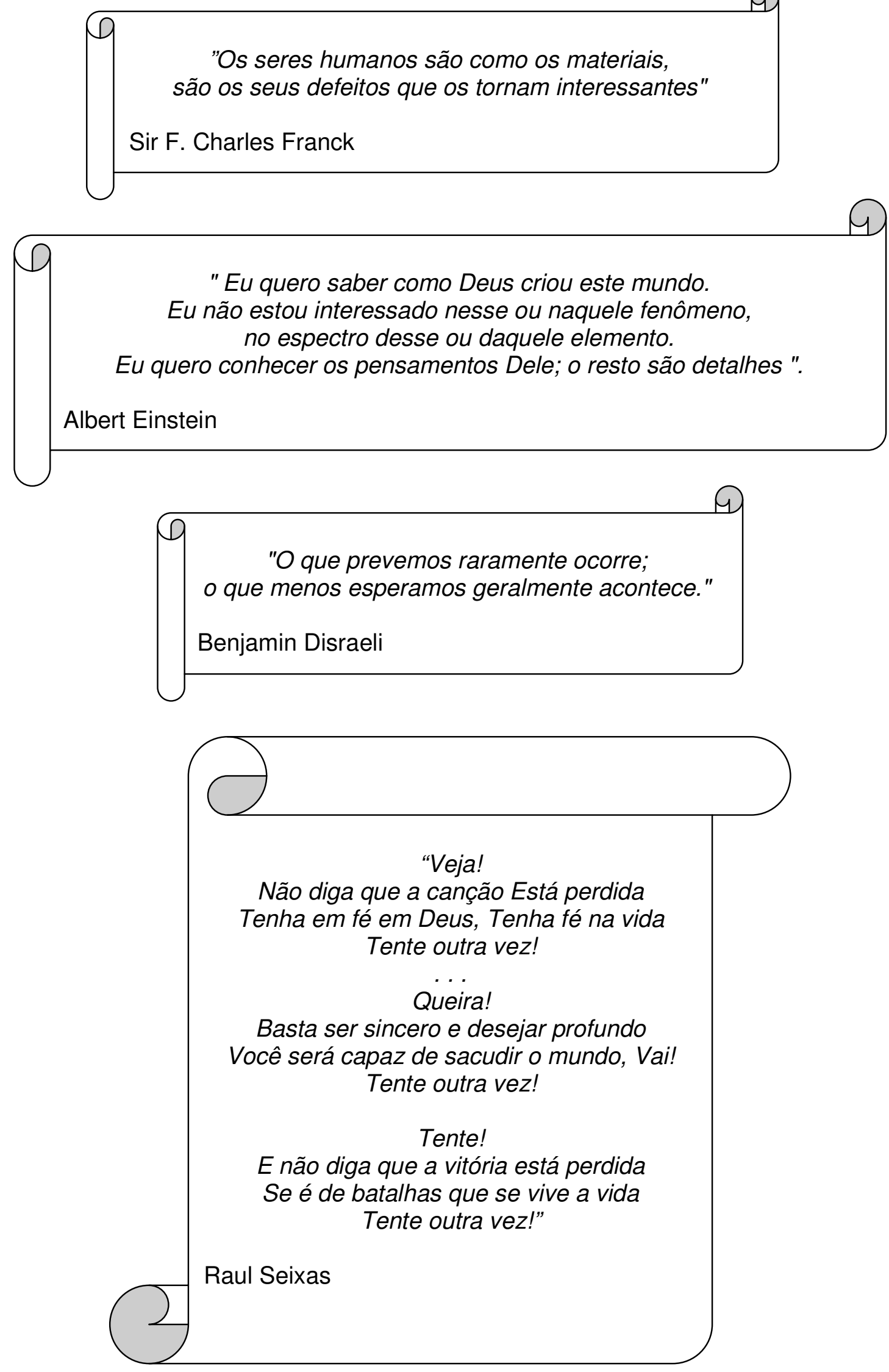
OCTAVO DÍA

Shakira Isabel Mebarak Ripoli

El octavo día Dios después de tanto trabajar

Para liberar tensiones luego ya de revisar

Fijo todo está muy bien es hora de descansar

$Y$ se fue a dar un paseo por el espacio sideral

Quién se iba a imaginar

que el mismo Dios al regresar

iba a encontrarlo todo en un desorden infernal

Y que se iba a convertir en un desempleado más

De la tasa que anualmente está creciendo

sin parar

Desde ese entonces hay quienes lo han visto

Solo en las calles transitar

Anda esperando paciente por alguien

Con quien al menos tranquilo

Pueda conversar

Mientras tanto este mundo gira y gira

Sin poderlo detener

$Y$ aquí abajo unos cuantos nos manejan

Como fichas de ajedrez

No soy la clase de idiota

Que se deja convencer

Pero digo la verdad

$Y$ hasta un ciego lo puede ver

Si a falta de ocupación

O de excesiva soledad

Dios no resistiera más

$Y$ se marchara a otro lugar

Sería nuestra perdición

No habría otro remedio más

Que adorar a Michael Jackson

A Bill Clinton o a Tarzán

Es más difícil se rey sin corona

Que una persona más normal

Pobre de Dios que no sale en revistas

Que no es modelo ni artista o de familia real

Mientras tanto este mundo gira y gira

Sin poderlo detener

$Y$ aquí abajo unos cuantos nos manejan

Como fichas de ajedrez

No soy la clase de idiota

Que se deja convencer

Pero digo la verdad

$Y$ hasta un ciego lo puede ver 


\section{AGRADECIMENTOS}

Primeira e principalmente a Deus todo-poderoso pelo dom da vida e pelo seu imenso amor, sempre me guiando, dando-me forças para aprender e crescer durante cada momento da minha vida.

Ao orientador Dr. Almir Oliveira Neto pela amizade, confiança, atenção, apoio e empenho em me auxiliar em diversos momentos e pelos valiosos ensinamentos proporcionados ao longo do desenvolvimento deste trabalho.

Ao Dr. Estevam Spinacé a quem também agradeço pela co-orientação, amizade, atenção e valiosos ensinamentos e discussões essenciais para minha formação e para realização deste trabalho.

A Dra. Elisabete I. Santiago pela amizade, pela ajuda dentro e fora do laboratório, pelos conselhos, ensinamentos e discussões científicas.

Ao Dr. Marcelo Linardi pela disponibilidade em nos atender e pelo empenho em manter a infra-estrutura do $\mathrm{CCCH}$, garantindo os meios necessários para a elaboração deste trabalho.

A Dra. Martha L. Mora Bejarano pela amizade, dedicação, pelos conselhos e ensinamentos científicos e pela ajuda com a língua espanhola.

A Dra. Luciana Farias pela amizade, pelo auxílio com as medidas, pelas sugestões e pela alegria e disposição para ensinar.

Aos Técnicos Cebola e Cebolinha que ajudaram nas medidas de EDX e MET ao MSc. Dionísio e MSc. Ricardo pelo auxílio nas análises de DRX.

Aos demais professores da Pós-Graduação do IPEN Waldemar, Denise, Christina, Oscar, Wagner e André, aos solícitos funcionários das bibliotecas do IPEN, do IFUSP, do IQUSP e da EPUSP e a Dra. Ruth Hinrichs da UFRGS pela ajuda e discussão das FFT nas imagens de MET. 
Ao Dr. João Guilherme Rocha Poço do IPT pelas correções, sugestões e pela oportunidade concedida.

A todos os amigos do IPEN especialmente a Vilmária, Gaúcho e Michele, Roberta, Suelanny, Adriano, Adriana, Alexandre, Bruno, Carla, Carol, Chiba, Clayton, Dionísio, Edgar, Eliana Aricó, Eliana Godói, Eric, Evelyn, Fábio, Gabi, Gustavo, Helô, Ilze, Juliana, Karol, Lilian, Marcela, Marcelo do Carmo, Mauro, Muso, Nakaoka, Paçoca, Panka, Pedro, Reinaldo, Ricardo, Ricardinho, Rita, Rudy, Teonas, Thais, Thiago, Tonho e Unai e todos que de alguma forma ajudaram na realização deste trabalho.

Aos bons e velhos amigos Wagner, Rodrigo, Lú, Paula, Berta, Xande e a todos os queridos amigos do bairro.

A Tábata pelo amor, companheirismo e compreensão e a sua amável família pelo carinho e hospitalidade.

Ao Matheus e queridos primos: Priscila, Vivian, Bruno, Samanta, Roberta, Paloma, Pablo, Paulo, Guillermo, Carmen, Juliane, Rodrigo, Nilo, Nevile, e Artur. Ao meu pai Roberto, ao meu avô Ademar e a todos os meus TIOS e TIAS que muito me apoiaram e incentivaram meus estudos e a toda minha família por todo amor e compreensão.

E em especial aquelas que sempre estarão comigo, a minha mãe Helaine e minha irmã Sylmara, e a minha avó Alaide (In Memorian) pelo amor incondicional, união, carinho, paciência, apoio e dedicação à minha formação pessoal e acadêmica.

A CAPES pela bolsa de Mestrado, ao $\mathrm{CCCH}$ e a CPG do IPEN pelos auxílios concedidos para as participações em congressos. 


\section{SUMÁRIO}

RESUMO

Página

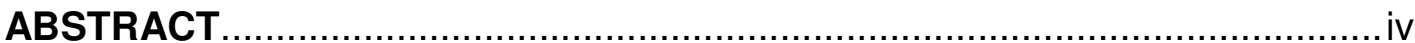

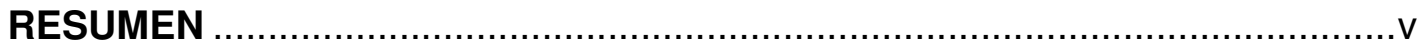

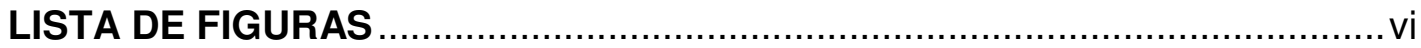

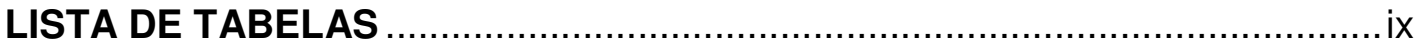

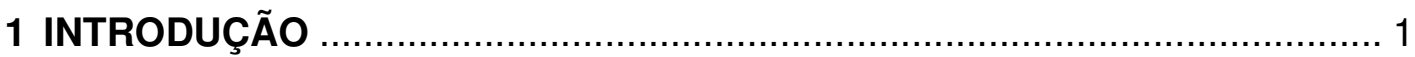

1.1 Célula a combustível ................................................................... 2

1.1.1 Célula a combustível do tipo PEM........................................... 3

1.2 Metanol ............................................................................................... 7

1.3 Etanol ..................................................................................... 10

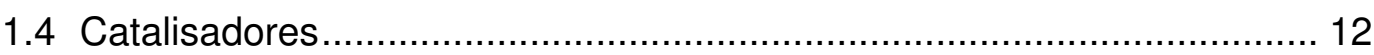

1.5 Métodos de Preparação de Eletrocatalisadores .................................. 14

2 OBJETIVOS

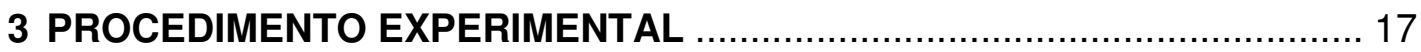

3.1 Preparação dos eletrocatalisadores ........................................ 17

3.1.1 Método da redução química por ácido cítrico ............................. 17

3.1.1.1 Variação da concentração do agente estabilizante ........ 19

3.1.1.2 Variação da composição atômica entre a platina e segundo metal

3.2 Caracterização dos eletrocatalisadores ……................................... 20

3.2.1 Caracterização físico-química ................................................. 20

3.2.1.1 Espectroscopia Energia Dispersiva de Raios X (EDX) ... 20

3.2.1.2 Difração de Raios X (DRX) .................................... 21

3.2.1.3 Microscopia Eletrônica de Transmissão (MET) .............. 23

3.2.2 Caracterização eletroquímica ....................................................... 24

3.2.2.1 Preparação do Eletrodo de Trabalho (eletrodo de camada

fina porosa) .......................................................................... 25

3.2.2.2 Voltametria Cíclica.................................................. 26

3.2.2.3 Cronoamperometria ............................................. 26

3.2.3 Testes em Célula a Combustível ................................................ 27

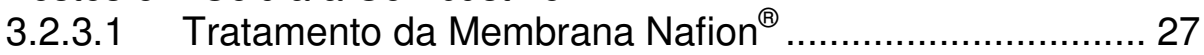

3.2.3.2 Preparação dos eletrodos......................................... 27

3.2.3.2.1 Ânodos....................................................... 28

3.2.3.2.2 Cátodos .................................................... 28

3.2.3.3 Curvas de Polarização................................................. 29 
4 RESULTADOS E DISCUSSÕES 31

4.1 Eletrocatalisadores PtRu/C 32 4.1.1 Catalisadores PtRu preparados em diferentes composições atômicas pela melhor condição de síntese.

4.2 Eletrocatalisadores $\mathrm{PtSn} / \mathrm{C}$ 53 4.2.1 Catalisadores PtSn preparados em diferentes composições atômicas pela melhor condição de síntese. 60

4.3 Eletro-oxidação de metanol (Comparação PtRu/C e PtSn/C) .73

4.4 Eletro-oxidação de etanol (Comparação PtRu/C e PtSn/C) .77

5 CONCLUSÕES 83

6 PROPOSTAS PARA TRABALHOS FUTUROS 87 REFERÊNCIAS BIBLIOGRÁFICAS 89 


\title{
PREPARAÇÃO E CARACTERIZAÇÃO DE ELETROCATALISADORES PtRu/C E PtSn/C VIA REDUÇÃO QUÍMICA POR ÁCIDO CÍTRICO PARA OXIDAÇÃO DIRETA DE ALCOOÓIS EM CÉLULAS A COMBUSTÍVEL TIPO PEM.
}

\author{
Roberto Willyan Ramon Verjulio da Silva
}

\section{RESUMO}

Neste trabalho, os sistemas de eletrocatalisadores platina-rutênio $(\mathrm{PtRu} / \mathrm{C})$ e platina-estanho $(\mathrm{PtSn} / \mathrm{C})$ suportados em carbono de alta área superficial XC72R (Cabot) foram preparados pela redução química de precursores metálicos em solução usando o ácido cítrico como agente redutor. Os eletrocatalisadores foram preparados em diferentes valores de $\mathrm{pH}$, com 0 objetivo de obter as condições de sínteses mais otimizadas para cada um dos sistemas preparados. O método otimizado mostrou-se eficiente na redução e ancoragem de todos os metais presente em solução, sendo possível preparar tanto catalisadores com baixos teores de segundo metal (razão atômica entre $\mathrm{Pt}: \mathrm{M}=90: 10)$ quanto catalisadores com altos teores de segundo metal (Pt:M = 50:50).

Os eletrocatalisadores obtidos foram caracterizados por espectroscopia de energia dispersiva de raios $X$, difração de raios $X$ e microscopia eletrônica de transmissão. A atividade frente a eletro-oxidação de metanol e etanol foi avaliada através de voltametria cíclica e cronoamperometria em célula eletroquímica. Para os catalisadores com melhores desempenhos eletroquímicos foram realizados experimentos em célula a combustível unitária alimentada diretamente por metanol ou etanol. O desempenho dos eletrocatalisadores preparados foi comparado com 0 desempenho dos eletrocatalisadores comerciais $\mathrm{Pt}_{50} \mathrm{Ru}_{50} / \mathrm{C}$ e $\mathrm{Pt}_{75} \mathrm{Sn}_{25} / \mathrm{C}$ da linha HP (High Performance) fornecidos pela E-TEK, considerados como referência nos estudos frente a eletro-oxidação de alcoóis.

Para eletro-oxidação do metanol foram obtidos eletrocatalisadores com desempenho comparável ao E-TEK e para eletro-oxidação de etanol foram obtidos eletrocalisadores com desempenho superior aos catalisadores E-TEK. 


\title{
PREPARATION AND CHARACTERIZATION OF PtRu/C AND PtSn/C ELECTROCATALYSTS USING THE CITRIC ACIDIC CHEMICAL REDUCTION PROCESS FOR DIRECT ALCOHOL FUEL CELL (DAFC).
}

\author{
Roberto Willyan Ramon Verjulio da Silva
}

\begin{abstract}
In this work, platinum ruthenium $(\mathrm{PtRu} / \mathrm{C})$ and platinum tin $(\mathrm{PtSn} / \mathrm{C})$ electrocatalysts were prepared by a chemical reduction process using citric acid as reducing agent and high surface area Vulcan Carbon $\mathrm{XC72R}$ (Cabot) as supports.

The PtRu/C and PtSn/C catalysts were characterized by energy dispersive X-ray spectroscopy, X-ray diffraction and transmission electron microscopy.

The electro-oxidation of methanol and ethanol were studied at room temperature by cyclic voltammetry and chronoamperometry. Single fuel cell experiments were carried at $90{ }^{\circ} \mathrm{C}$ and the performance of the homemade electrocatalysts prepared by citric acid method in optimized conditions were compared with commercial $\mathrm{Pt}_{50} \mathrm{Ru}_{50} / \mathrm{C}$ and $\mathrm{Pt}_{75} \mathrm{Sn}_{25} / \mathrm{C}$ E-TEK HP (High Performance) catalysts.

For methanol's electro-oxidation electrocatalysts with comparable E-TEK's catalysts performance were obtained and for ethanol's electro-oxidation electrocatalysts with superior performance than E-TEK's electrocatalysts were obtained.
\end{abstract}




\title{
PREPARACIÓN Y CARACTERIZACIÓN DE ELECTROCATALIZADORES PtRu/C Y PtSn/C VIA REDUCCIÓN QUÍMICA CON ÁCIDO CÍTRICO PARA LA OXIDACIÓN DIRECTA DEL ALCOHOL EN CELDAS DE COMBUSTIBLE TIPO PEM.
}

\author{
Roberto Willyan Ramon Verjulio Da Silva
}

\section{RESUMEN}

En este trabajo, los sistemas de electrocatalizadores platina-rutenio $(\mathrm{PtRu} / \mathrm{C})$ y platina-estaño $(\mathrm{PtSn} / \mathrm{C})$ soportados en carbón de alta área superficial fueron preparados por medio del método de reducción química de precursores metálicos en solución, usando el ácido cítrico como agente reductor. Los electrocatalizadores fueron preparados a diferentes valores de $\mathrm{pH}$, con el objetivo de obtener las condiciones óptimas de síntesis para cada uno de los sistemas preparados. El método optimizado se mostró eficiente en la reducción y soporte de todos los metales presentes en solución, haciendo posible preparar catalizadores con bajos (razón atómica Pt:M = 90:10) y altos porcentajes del segundo metal (razón atómica Pt:M = 50:50).

Los electrocatalizadores fueron caracterizados por espectroscopia de energía dispersiva de rayos $\mathrm{X}$, difracción de rayos $\mathrm{X}$ y microscopia electrónica de transmisión. La actividad frente a la electrooxidación de metanol y etanol fue evaluada a través de voltametría cíclica e cronoamperometría en celdas electroquímicas. Para los catalizadores con mejores desempeños electroquímicos fueron realizadas curvas de polarización en celdas de combustible unitarias utilizando como combustible metanol o etanol. Los resultados obtenidos en la celda de combustible, utilizando electrocatalizadores preparados por el método de reducción con ácido cítrico fueron comparados con los electrocatalizadores comerciales $\mathrm{Pt}_{50} \mathrm{Ru}_{50} / \mathrm{C}$ y $\mathrm{Pt}_{75} \mathrm{Sn}_{25} / \mathrm{C}$ de la línea HP (High Performance) producidos por la empresa E-TEK, considerados como referencia en los estudios de electrooxidación de alcoholes.

Para la electrooxidación de metanol fueron obtenidos electrocatalizadores con desempeño comparable al E-TEK y para la electrooxidación de etanol fueron logrados electrocatalizadores con desempeño superior a los electrocatalizadores HP E-TEK. 


\section{LISTA DE FIGURAS}

Figura 1.1 - Representação esquemática de uma célula a combustível do tipo PEM. Em destaque, esquema que mostra o processo eletroquímico numa PEMFC e as interfaces trifásicas de reação catódica e anódica, adaptado da referência [8]. 4

Figura 1.2 - Desenho esquemático da curva de polarização de uma célula a combustível dividida em regiões onde predominam certas perdas por sobrepotencias.

Figura 1.3 - Representação esquemático do mecanismo de oxidação do metanol, proposto por Iwasita e colaboradores.

Figura 3.1 - Fluxograma do método de preparação de eletrocatalisadores via redução química por ácido cítrico [63]. 18

Figura 3.2 - Fluxograma da preparação dos eletrocatalisadores, onde M é o segundo metal Ru e Sn dos catalisadores PtRu/C e PtSn/C preparados.

Figura 3.3 - Diagrama esquemático do eletrodo de camada fina porosa.

Figura 3.4 - Desenho esquemático em vista explodida dos componentes da célula a combustível tipo PEMFC utilizada, importada da empresa ElectroChem.

Figura 4.1 - Difratogramas de raios $X$ do catalisador $\mathrm{Pt} / \mathrm{C}$ e dos eletrocatalisadores $\mathrm{Pt}_{50} \mathrm{Ru}_{50} / \mathrm{C}$ preparados via ácido cítrico em diferentes razões entre (Metais: $\mathrm{KOH}$ ). 33

Figura 4.2 - a) Comparação dos valores de corrente para $\mathrm{Pt}_{50} \mathrm{Ru}_{50} / \mathrm{C}$ preparados por ácido cítrico variando-se a razão molar entre M:KOH de 1:5 e 1:10 na presença de $1 \mathrm{~mol} \cdot \mathrm{L}^{-1}$ de metanol, considerando-se apenas a varredura anódica, corrigida pelo voltamograma base. b) comparação das curvas cronoamperométricas para os mesmos catalisadores com potencial fixo de $500 \mathrm{mV}$ por $30 \mathrm{~min}$.

Figura 4.3 - a) Comparação dos valores de corrente para $\mathrm{Pt}_{50} \mathrm{Ru}_{50} / \mathrm{C}$ preparados por ácido cítrico variando-se a razão molar entre M:KOH de 1:5 e 1:10 na presença de $1 \mathrm{~mol} \cdot \mathrm{L}^{-1}$ de etanol, considerando-se apenas a varredura anódica, corrigida pelo voltamograma base. b) comparação das curvas cronoamperométricas para os mesmos catalisadores com potencial fixo de $500 \mathrm{mV}$ por $30 \mathrm{~min}$.

Figura 4.4 - Difratogramas de raios $X$ dos eletrocatalisadores comerciais E-TEK e PtRu/C preparados com diferentes teores de Ru. 39

Figura 4.5 - Imagens de microscopia eletrônica de transmissão dos catalisadores $\mathrm{PtRu} / \mathrm{C}$ e seus respectivos histogramas da freqüência do tamanho de partículas.

Figura 4.6 - a) Comparação dos valores de corrente para os catalisadores $\mathrm{PtRu} / \mathrm{C}$ preparados por ácido cítrico nas composições atômicas entre Pt:Ru de 90:10, 80:20, 70:30, 60:40 e 50:50 e catalisador E-TEK na presença de $1 \mathrm{~mol} \cdot \mathrm{L}^{-1}$ de metanol, considerando-se apenas a varredura anódica, corrigida pelo voltamograma base e b) comparação das curvas cronoamperométricas para os mesmos catalisadores com potencial fixo de $500 \mathrm{mV}$ por $30 \mathrm{~min}$. 
Figura 4.7 - Curvas de polarização para $\mathrm{Pt}_{50} \mathrm{Ru}_{50} / \mathrm{C}, \mathrm{Pt}_{80} \mathrm{Ru}_{20} / \mathrm{C}$ e $\mathrm{Pt} / \mathrm{C}$, $\mathrm{Pt}_{50} \mathrm{Ru}_{50} / \mathrm{C}$ (E-TEK), a $90^{\circ} \mathrm{C}$, fluxo $\cong 1 \mathrm{~mL} \min ^{-1}$ de solução de Metanol (2 mol $\mathrm{L}^{-1}$ ), fluxo de $\mathrm{O}_{2}$ de $500 \mathrm{~mL} \mathrm{~min}^{-1}$, em diferentes pressões na saída do $\mathrm{O}_{2}$ de: a) 1 bar; b) 2 bar e c) 3 bar. .

Figura 4.8 - a) Comparação dos valores de corrente para os catalisadores $\mathrm{PtRu} / \mathrm{C}$ preparados por ácido cítrico nas composições atômicas entre Pt:Ru de 90:10, 80:20, 70:30, 60:40 e 50:50 e catalisador comercial da E-TEK na presença de $1 \mathrm{~mol} \cdot \mathrm{L}^{-1}$ de etanol, considerando-se apenas a varredura anódica, corrigida pelo voltamograma base e b) comparação das curvas cronoamperométricas para os mesmos catalisadores com potencial fixo de $500 \mathrm{mV}$ por $30 \mathrm{~min}$

Figura 4.9 - Curvas de polarização para $\mathrm{Pt}_{50} \mathrm{Ru}_{50} / \mathrm{C}, \mathrm{Pt}_{80} \mathrm{Ru}_{20} / \mathrm{C}$ e Pt/C, $\mathrm{Pt}_{50} \mathrm{Ru}_{50} / \mathrm{C}$ (E-TEK), a $90^{\circ} \mathrm{C}$, fluxo $\cong 1 \mathrm{~mL} \mathrm{~min}^{-1}$ de solução de EtOH (2 mol $\mathrm{L}^{-1}$ ), fluxo de $\mathrm{O}_{2}$ de $500 \mathrm{~mL} \mathrm{~min}^{-1}$, em diferentes pressões na saída do $\mathrm{O}_{2}$ de: a) 1 bar; b) 2 bar e c) 3 bar. 51

Figura 4.10 - Difratogramas de raios $X$ do catalisador $\mathrm{Pt} / \mathrm{C}$ e dos eletrocatalisadores $\mathrm{Pt}_{50} \mathrm{Sn}_{50} / \mathrm{C}$ preparados via ácido cítrico em diferentes razões entre (Metais: $\mathrm{KOH}$ ).

Figura 4.11 - a) Comparação dos valores de corrente para $\mathrm{Pt}_{50} \mathrm{Sn}_{50} / \mathrm{C}$ preparados por ácido cítrico variando-se a razão molar entre M:KOH de 1:5 e 1:10 na presença de $1 \mathrm{~mol} \cdot \mathrm{L}^{-1}$ de metanol, considerando-se apenas a varredura anódica, corrigida pelo voltamograma base. b) comparação das curvas cronoamperométricas para os mesmos catalisadores com potencial fixo de $500 \mathrm{mV}$ por $30 \mathrm{~min}$. 57

Figura 4.12 - a) Comparação dos valores de corrente para $\mathrm{Pt}_{50} \mathrm{Sn}_{50} / \mathrm{C}$ preparados por ácido cítrico variando-se a razão molar entre $\mathrm{M}: \mathrm{KOH}$ de 1:5 e 1:10 na presença de $1 \mathrm{~mol} \cdot \mathrm{L}^{-1}$ de etanol, considerando-se apenas a varredura anódica, corrigida pelo voltamograma base. b) comparação das curvas cronoamperométricas para os mesmos catalisadores com potencial fixo de $500 \mathrm{mV}$ por $30 \mathrm{~min}$. 58

Figura 4.13 - Difratogramas de raios $X$ dos catalisadores comerciais E-TEK e $\mathrm{PtSn} / \mathrm{C}$ preparados com diferentes teores de $\mathrm{Sn}$ 60

Figura 4.14 - Imagens de microscopia eletrônica de transmissão dos catalisadores $\mathrm{PtSn} / \mathrm{C}$ e seus respectivos histogramas da freqüência do tamanho de partículas. 63

Figura 4.15 - a) Comparação dos valores de corrente para os catalisadores $\mathrm{PtSn} / \mathrm{C}$ preparados por ácido cítrico nas composições atômicas entre Pt:Sn de 90:10, 80:20, 70:30, 60:40 e 50:50 e catalisador comercial da E-TEK na presença de $1 \mathrm{~mol} \cdot \mathrm{L}^{-1}$ de metanol, considerando-se apenas a varredura anódica, corrigida pelo voltamograma base. b) comparação das curvas cronoamperométricas para os mesmos catalisadores com potencial fixo de $500 \mathrm{mV}$ por $30 \mathrm{~min}$ 64

Figura 4.16 - Curvas de polarização para $\mathrm{Pt}_{50} \mathrm{Sn}_{50} / \mathrm{C}, \mathrm{Pt}_{60} \mathrm{Sn}_{40} / \mathrm{C}$ e Pt/C, $\mathrm{Pt}_{75} \mathrm{Sn}_{25} / \mathrm{C}$ (E-TEK), a $90^{\circ} \mathrm{C}$, fluxo $\cong 1 \mathrm{~mL} \mathrm{~min}^{-1}$ de solução de metanol (2 mol $\mathrm{L}^{-1}$ ), fluxo de $\mathrm{O}_{2}$ de $500 \mathrm{~mL} \mathrm{~min}^{-1}$, em diferentes pressões na saída do $\mathrm{O}_{2}$ de: a) 1 bar; b) 2 bar e c) 3 bar. 67 
Figura 4.17 - a) Comparação dos valores de corrente para os catalisadores $\mathrm{PtSn} / \mathrm{C}$ preparados por ácido cítrico nas composições atômicas entre Pt:Sn de 90:10, 80:20, 70:30, 60:40 e 50:50 e catalisador comercial da E-TEK na presença de $1 \mathrm{~mol} \cdot \mathrm{L}^{-1}$ de etanol, considerando-se apenas a varredura anódica, corrigida pelo voltamograma base. b) comparação das curvas cronoamperométricas para os mesmos catalisadores com potencial fixo de $500 \mathrm{mV}$ por $30 \mathrm{~min}$.

Figura 4.18 - Curvas de polarização para $\mathrm{Pt}_{50} \mathrm{Sn}_{50} / \mathrm{C}, \mathrm{Pt}_{60} \mathrm{Sn}_{40} / \mathrm{C}$ e $\mathrm{Pt} / \mathrm{C}$, $\mathrm{Pt}_{75} \mathrm{Sn}_{25} / \mathrm{C}$ (E-TEK), a $90^{\circ} \mathrm{C}$, fluxo $\cong 1 \mathrm{~mL} \mathrm{~min}^{-1}$ de solução de etanol (2 mol $\mathrm{L}^{-1}$ ), fluxo de $\mathrm{O}_{2}$ de $500 \mathrm{~mL} \mathrm{~min}^{-1}$, em diferentes pressões na saída do $\mathrm{O}_{2}$ de: a) 1 bar; b) 2 bar e c) 3 bar. 71

Figura 4.19 - a) Comparação dos valores de corrente para os catalisadores $\mathrm{PtRu} / \mathrm{C}$ e PtSn/C preparados por ácido cítrico e catalisadores comerciais da E-TEK na presença de $1 \mathrm{~mol} \cdot \mathrm{L}^{-1}$ de metanol, considerando-se apenas a varredura anódica, corrigida pelo voltamograma base. b) comparação das curvas cronoamperométricas para os mesmos catalisadores com potencial fixo de $500 \mathrm{mV}$ por $30 \mathrm{~min}$

73

Figura 4.20 - Comparação das curvas de polarização de todos os MEAs testados em DMFC $5 \mathrm{~cm}^{2}$, Metanol $2 \mathrm{~mol} \mathrm{~L}^{-1} \mathrm{com}$ fluxo $\cong 1 \mathrm{~mL} \mathrm{~min}^{-1}$, Temperatura da Cel $=90^{\circ} \mathrm{C}$, Temperatura $\mathrm{O}_{2}=90^{\circ} \mathrm{C}$, Fluxo $\mathrm{O}_{2}=500 \mathrm{~mL} \mathrm{~min}{ }^{-1}$, Pressão de saída $\mathrm{O}_{2}=2$ bar. 75

Figura 4.21 - Comparação de densidades de potência de todos os MEAs testados em DMFC $5 \mathrm{~cm}^{2}$, Metanol $2 \mathrm{~mol} \mathrm{~L}^{-1} \mathrm{com}$ fluxo $\cong 1 \mathrm{~mL} \mathrm{~min}^{-1}$, Temperatura da Cel $=90^{\circ} \mathrm{C}$, Temperatura $\mathrm{O}_{2}=90^{\circ} \mathrm{C}$, Fluxo $\mathrm{O}_{2}=500 \mathrm{~mL}$ min $^{-1}$, Pressão de saída $\mathrm{O}_{2}=2$ bar. 75

Figura 4.22 - a) Comparação dos valores de corrente para os catalisadores $\mathrm{PtRu} / \mathrm{C}$ e PtSn/C preparados por ácido cítrico e catalisadores comercial da E-TEK na presença de $1 \mathrm{~mol} \cdot \mathrm{L}^{-1}$ de etanol, considerando-se apenas a varredura anódica, corrigida pelo voltamograma base. b) comparação das curvas cronoamperométricas para os mesmos catalisadores com potencial fixo de $500 \mathrm{mV}$ por $30 \mathrm{~min}$. 77

Figura 4.23 - Comparação das curvas de polarização de todos os MEAs testados em DEFC $5 \mathrm{~cm}^{2}$, Etanol $2 \mathrm{~mol} \mathrm{~L}^{-1}$ com fluxo $\cong 1 \mathrm{~mL} \mathrm{~min}^{-1}$, Temperatura da Cel $=90^{\circ} \mathrm{C}$, Temperatura $\mathrm{O}_{2}=90^{\circ} \mathrm{C}$, Fluxo $\mathrm{O}_{2}=500 \mathrm{~mL}$ $\min ^{-1}$, Pressão de saída $\mathrm{O}_{2}=2$ bar. 79

Figura 4.24 - Comparação das densidades de potência de todos os MEAs testados em DEFC $5 \mathrm{~cm}^{2}$, Etanol $2 \mathrm{~mol} \mathrm{~L}^{-1}$ com fluxo $\cong 1 \mathrm{~mL} \mathrm{~min}^{-1}$, Temperatura da Cel $=90^{\circ} \mathrm{C}$, Temperatura $\mathrm{O}_{2}=90^{\circ} \mathrm{C}$, Fluxo $\mathrm{O}_{2}=500 \mathrm{~mL}$ $\min ^{-1}$, Pressão de saída $\mathrm{O}_{2}=2$ bar 


\section{LISTA DE TABELAS}

Tabela 1 - Composição atômica entre Pt:Ru (EDX) para os catalisadores Pt:Ru ancorados em Carbono preparados com ácido cítrico variando-se a concentração de $\mathrm{KOH}$, estimativa de tamanho médio de cristalito $(d)$ e parâmetro de rede (a) calculados a partir dos difratogramas de DRX, o $\mathrm{pH}$ da síntese e a coloração do filtrado.

Tabela 2 - Composição atômica entre Pt:Ru (EDX) para os catalisadores preparados por ácido cítrico na razão molar entre Metais:KOH (1:10) variando-se a composição atômica, dados de diâmetro e parâmetros de rede calculados por DRX e o pH da síntese e a coloração do filtrado.

Tabela 3 - Composição atômica entre Pt:Sn (EDX) para os catalisadores Pt:Sn ancorados em Carbono preparados com ácido cítrico variando-se a concentração de $\mathrm{KOH}$, estimativa de tamanho médio de cristalito $(d) \mathrm{e}$ parâmetro de rede (a) calculados a partir dos difratogramas de DRX, o $\mathrm{pH}$ da síntese e a coloração do filtrado. 55

Tabela 4 - Composição atômica entre Pt:Sn (EDX) para os catalisadores preparados por ácido cítrico na razão molar entre Metais:KOH (1:5) variando-se a composição atômica, dados de diâmetro e parâmetros de rede calculados por $\mathrm{DRX}$ e $\circ \mathrm{pH}$ da síntese e a coloração do filtrado. 61

Tabela 5 - Tamanhos de cristalito $(d)$ e de partícula $(t)$ e comparação da máxima densidade de potência obtida em cada condição de pressurização do cátodo da DAFC. Em destaque, as melhores condições obtidas para oxidação de cada álcool. 


\section{INTRODUÇÃO}

A industrialização ao longo do século $X X$ propiciou mudanças radicais nos mais variados setores da atividade humana, de forma que atualmente vivemos numa sociedade quase que completamente automatizada, que tem na eletricidade a sua base de funcionamento. Este elevado desenvolvimento e a complexa infra-estrutura da sociedade atual estão baseados quase que completamente na queima de combustíveis fósseis para a geração de energia. Entretanto, o consumo indiscriminado desses combustíveis fósseis trouxe, também, algumas conseqüências, tais como a crescente poluição ambiental e todos os variados problemas oriundos da degradação do meio ambiente, como inúmeros males à saúde, até alterações no clima devido ao aquecimento global. Esta situação é agravada pela crescente demanda de energia que acompanha o crescimento da população mundial [1].

Esta demanda crescente de energia aliada ao iminente esgotamento de fontes energéticas não renováveis e aos problemas ambientais ocasionados pela queima dos combustíveis fósseis fez com que, nas ultimas décadas, se intensificasse a busca por fontes energéticas renováveis e de baixo impacto ambiental, que estejam de acordo com a necessidade da manutenção dos recursos naturais sustentáveis.

Dentre as alternativas propostas para contribuir com a solução dessa problemática energética, uma das mais promissoras está na aplicação de células a combustível como fontes de energia que apresentam diversas aplicações tecnológicas. Estas podem ser estacionárias para geração de energia descentralizada, ou móveis (para tração de veículos automotores) ou 
ainda como fonte de energia para equipamentos portáteis (como computadores portáteis e celulares) $[2,3]$.

\subsection{Célula a combustível}

A célula a combustível é um dispositivo eletroquímico capaz de converter a energia química armazenada nos reagentes diretamente em energia elétrica e calor, através de um par de reações eletroquímicas acopladas, de forma contínua enquanto houver o abastecimento de reagentes na célula. Em sua configuração básica, a célula a combustível é composta de dois eletrodos separados por um eletrólito. No ânodo, eletrodo negativo (de onde saem os elétrons), ocorre a oxidação do combustível utilizado (hidrogênio, metanol, etanol ou outros combustíveis) e a formação de prótons, que são transportados através do eletrólito, no cátodo, eletrodo positivo (onde chegam os elétrons), acontece a reação de redução do oxigênio, com a formação de água. Para completar o circuito, há circulação dos elétrons (provenientes da reação de oxidação do combustível no ânodo) no circuito externo, os quais são responsáveis pela realização do trabalho elétrico. Ambas as reações, anódica e catódica, são heterogêneas e ocorrem na interface eletrodo/eletrólito, sendo catalisadas na superfície do catalisador [4].

As células a combustível se classificam pelo tipo de eletrólito utilizado e, conseqüentemente, pela temperatura de operação. Para células a combustível de alta temperatura de operação não há a necessidade da utilização de metais nobres como catalisadores, já que nesta faixa de temperaturas, o próprio metal do eletrodo (em geral não nobre) torna-se suficientemente ativo $[5,6]$. 
Os principais tipos de células de alta temperatura de operação (de $200^{\circ} \mathrm{C}$ até $1000^{\circ} \mathrm{C}$ ) são:

a) as células a carbonato fundido (Molten Carbonate Fuel Cell), ou MCFC;

b) as células de óxido sólido (Solid Oxide Fuel Cell), ou SOFC.

Os principais tipos de células de baixa temperatura de operação (de temperatura ambiente até $200{ }^{\circ} \mathrm{C}$ ) são:

a) as células alcalinas (Alkaline Fuel Cell), ou simplesmente AFC.

b) as células a ácido fosfórico (Phosphoric Acid Fuel Cell), ou PAFC.

c) as células a membrana polimérica trocadora de prótons (Proton Exchange Membrane Fuel Cell), ou PEMFC.

\subsubsection{Célula a combustível do tipo PEM.}

As PEMFCs operam na faixa de temperatura ambiente até $100{ }^{\circ} \mathrm{C}$ e são as mais promissoras como alternativas para a eletrotração, em substituição aos motores a combustão interna. Estas células possuem as vantagens de serem robustas e de fácil acionamento e desligamento e possuem alta eficiência e baixa (ou nenhuma) emissão de poluentes. Também se aplicam às unidades estacionárias geradoras de energia local e também para geradores portáteis de energia, como telefones celulares e laptops.

Como eletrólito polimérico utiliza-se a membrana Nafion ${ }^{\circledR}$, composta por um polímero perfluorado de tetrafluorpolietileno. As pontas das cadeias, onde se encontra o grupo sulfônico, formam uma espécie de "bolha" na estrutura, que se incha em contato com a água ou vapor d'água. Estas "bolhas", que são interligadas, são responsáveis pela condução de prótons e água pela membrana, sob o efeito de um campo elétrico. 
Nas células de baixa temperatura de operação as reações se processam nos chamados eletrodos de difusão gasosa, que são uma estrutura porosa condutora de elétrons do sistema eletrodo/eletrocatalisador a base de platina. A construção deste eletrodo tem como função a maximização da interface trifásica gás/líquido/sólido, aumentando consideravelmente a velocidade dos processos eletródicos [7].

Os eletrocatalisadores estudados neste trabalho visam aplicações em células a combustível do tipo PEM alimentadas diretamente por alcoóis (Direct Alcohol Fuel Cell) ou DAFC, conhecidas como DMFC (Direct Methanol Fuel Cell) para células PEM alimentadas diretamente por metanol e DEFC (Direct Ethanol Fuel Cell) células tipo PEM alimentadas diretamente por etanol.

$\mathrm{Na}$ Figura 1.1 encontra-se esquematizado os componentes de uma célula a combustível do tipo PEM e em destaque as reações eletroquímicas que ocorrem na interface trifásica dos eletrocatalisadores ativos, ou seja, naqueles onde há o contato entre o catalisador, o combustível e o eletrólito [8].

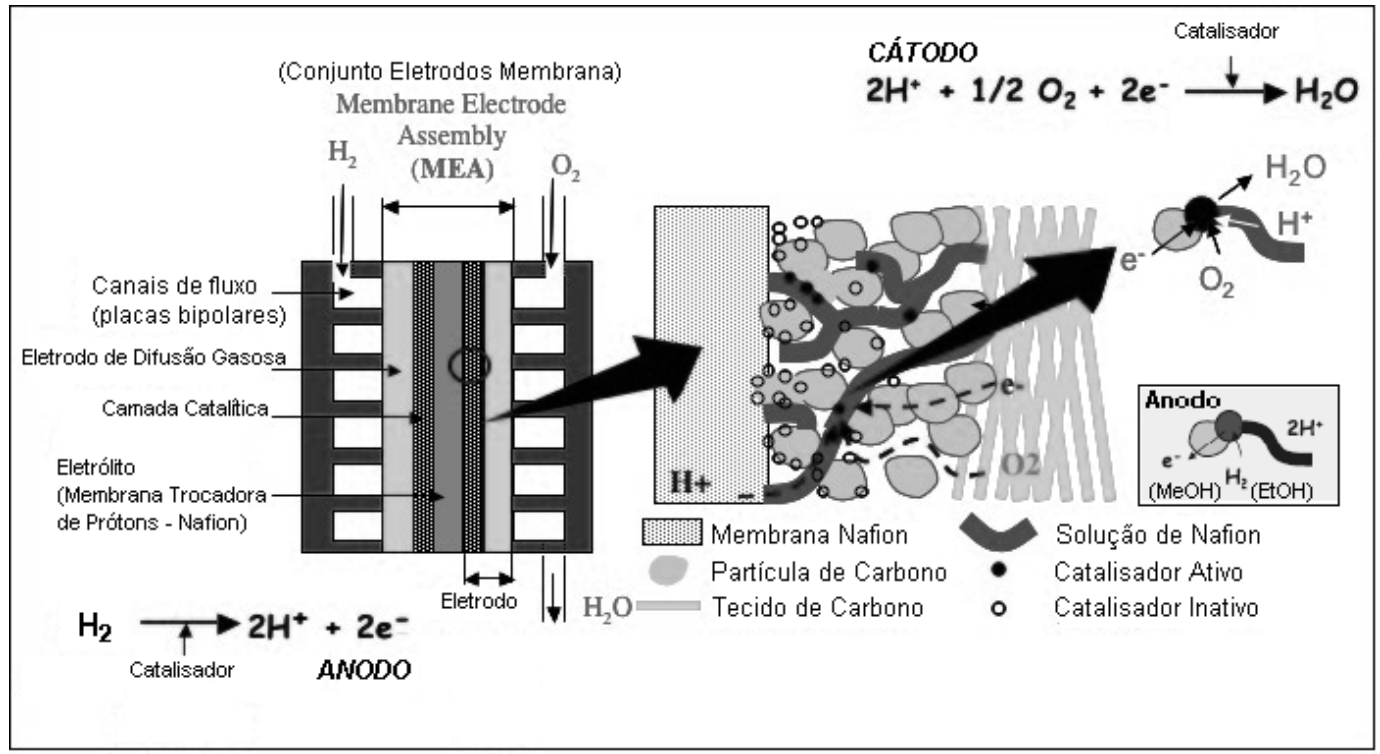

Figura 1.1 - Representação esquemática de uma célula a combustível do tipo PEM. Em destaque, esquema que mostra o processo eletroquímico numa PEMFC e as interfaces trifásicas de reação catódica e anódica, adaptado da referência [8]. 
Pesquisas em células a combustível no Brasil vêm sendo desenvolvidas desde o final da década de 70 em várias instituições. O governo brasileiro iniciou suas ações mais importantes e concretas na área, em 2002, este também já integra o IPHE (International Partnership for the Hydrogen Economy) que trabalha para o estabelecimento da "Economia do Hidrogênio" em nossa sociedade.

O Brasil está elaborando seu roteiro para a "Economia do Hidrogênio" e possui um programa nacional de pesquisa e desenvolvimento para a tecnologia de célula a combustível e hidrogênio (PROH2). Atualmente, várias instituições brasileiras estão atuando em áreas de pesquisa e desenvolvimento neste setor com vários projetos em andamento. Novas empresas nacionais já apresentam produtos para esta nova tecnologia (Electrocell, Unitech e Novocell, entre outras). O IPEN tem desempenhado um importante papel no cenário nacional e internacional para o desenvolvimento desta tecnologia [7].

O hidrogênio (líquido) possui densidade energética $\left(\sim 2,8 \mathrm{kWh} \mathrm{L}^{-1}\right.$ ou $\left.\sim 39 \mathrm{kWh} \mathrm{kg}^{-1}\right)$ comparável com a da gasolina $\left(\sim 9 \mathrm{kWh} \mathrm{L}^{-1}\right.$ ou $\left.\sim 12 \mathrm{kWh} \mathrm{kg}^{-1}\right)$ [9] e com a vantagem de ser um combustível que não polui a atmosfera. Para as células a combustível com hidrogênio e oxigênio deveria obter-se um potencial de circuito aberto, próximo ao potencial reversível da dupla $\mathrm{H}_{2} / \mathrm{O}_{2}$ que, à temperatura ambiente, é de $1,23 \mathrm{~V}$ vs ERH (Eletrodo Reversível de Hidrogênio). Na prática este valor não é atingido devido a perdas geradas pelo carregamento da dupla camada elétrica (sobrepotencial na região de equilíbrio a circuito aberto). Além disso, no catalisador a reação tem uma velocidade finita produzindo perdas por ativação, principalmente do cátodo, observadas em baixas correntes. À medida que se aumenta a exigência de corrente, 
começa a prevalecer uma perda devido à resistência ôhmica da célula e aos processos difusivos. Finalmente em regiões de correntes elevadas, os gases não conseguem atingir rapidamente o catalisador e o potencial cai rapidamente ficando o processo controlado pelo transporte de massa [10]. A Figura 1.2 mostra esquematicamente as características da curva de polarização, potencial versus densidade de corrente, de uma célula a combustível $\left(\mathrm{H}_{2} / \mathrm{O}_{2}\right)$ e as regiões onde há maior contribuição de cada perda por sobrepotencial.

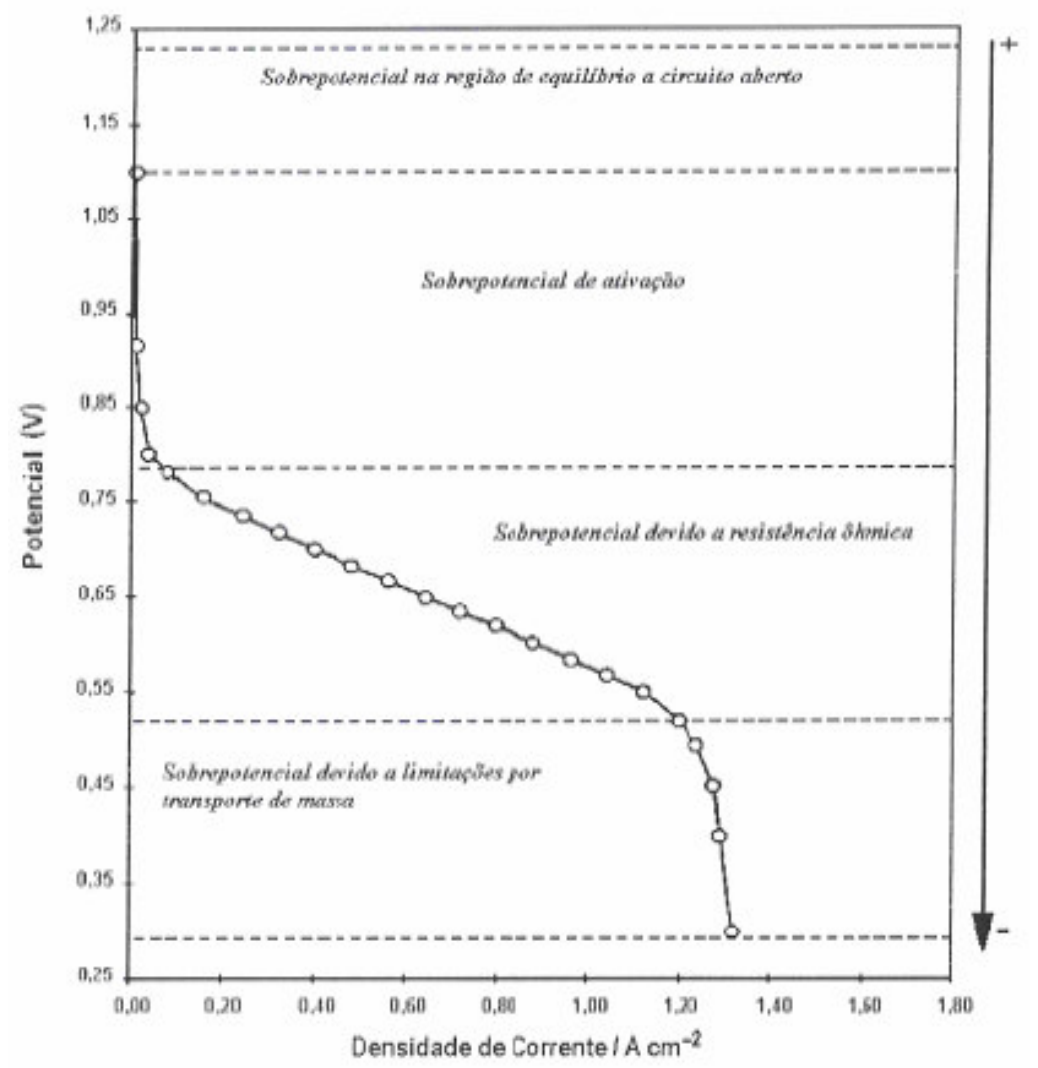

Figura 1.2 - Desenho esquemático da curva de polarização de uma célula a combustível dividida em regiões onde predominam certas perdas por sobrepotencias.

O hidrogênio pode ser obtido pela reforma a vapor de hidrocarbonetos ou pela eletrólise da água. Apesar de a eletrólise produzir hidrogênio de alta pureza seu custo é ainda razoavelmente maior do que o obtido pela reforma a vapor. Por outro lado, na reforma a vapor o hidrogênio obtido é bastante 
impuro, contendo cerca de $6-7 \%$ de CO. O monóxido de carbono não é tolerado nas células a combustível à baixa temperatura, pois envenena o catalisador de platina. Desse modo, é necessário reduzir seu conteúdo a menos de $10 \mathrm{ppm}$ [2]. Ultimamente o problema da presença de $\mathrm{CO}$ no hidrogênio está sendo contornado com o desenvolvimento de catalisadores mais tolerantes ao mesmo [11, 12]. Estes consistem em ligas de platina com certos metais de transição, como Ru, Sn, Mo, Os, Rh entre outros, que facilitam a oxidação do $\mathrm{CO}$ a $\mathrm{CO}_{2}[13,14]$. Desse modo níveis de $\mathrm{CO}$ de até 150 ppm têm sido tolerados [15].

No entanto o hidrogênio apresenta alguns inconvenientes operacionais e de infra-estrutura. A compressão, o armazenamento e a distribuição do hidrogênio requerem tecnologias relativamente sofisticadas e de custo elevado, o que dificulta o uso deste combustível, particularmente em certas aplicações que seriam de grande impacto, como a utilização em veículos. Devido a esta situação, têm surgido esforços significativos para desenvolver células a combustível que possam operar diretamente com combustíveis líquidos. Neste sentido, o combustível que atualmente apresenta resultado mais encorajador para o emprego direto em células a combustível é o metanol.

\subsection{Metanol}

A produção do metanol é um processo bem conhecido e não oferece os inconvenientes do hidrogênio de armazenamento e distribuição. Além disso, há vários outros fatores que o tornam interessantes, como por exemplo, a densidade energética $\left(\sim\right.$ 4,3 $\mathrm{kWh} \mathrm{L}^{-1}$ ou $\left.\sim 5,5 \mathrm{kWh} \mathrm{kg}^{-1}\right)$ e a eliminação de 
sistemas complexos de umidificação e térmicos que proporcionariam as células a metanol um custo menos elevado [16, 17].

As células a combustível de metanol direto (DMFC - Direct Methanol Fuel Cell) utilizam metanol na forma de vapor ou líquido como combustível e operam em baixas temperaturas $\left(<100^{\circ} \mathrm{C}\right)$. A DMFC tem um projeto semelhante a PEMFC, sendo composta por dois eletrodos porosos em contato com uma membrana trocadora de prótons.

A reação de eletro-oxidação completa do metanol envolve 6 elétrons, mas sua cinética é bastante lenta e com formação de intermediários fortemente adsorvidos. Um destes intermediários, o monóxido de carbono $\left(\mathrm{CO}_{\mathrm{ads}}\right)$, envenena o catalisador de platina, diminuindo assim o número de sítios ativos para futuras adsorções de álcool, podendo chegar até a impedir que a reação de eletro-oxidação prossiga caso seja atingida a concentração máxima tolerável.

A oxidação desses intermediários a $\mathrm{CO}_{2}$ requer a adsorção de espécies que contenham oxigênio $\left(\mathrm{OH}, \mathrm{H}_{2} \mathrm{O}\right)$ [18]. A platina sozinha não é suficientemente ativa para a oxidação do $\mathrm{CO}_{\mathrm{ads}}$ a $\mathrm{CO}_{2}$ a baixos potenciais e por isso se faz necessário utilizar materiais alternativos como ligas de platinarutênio $(P t R u)[19,20]$. Nestes catalisadores o metal ligado a platina forma óxidos superficiais em potenciais mais baixos que a platina, facilitando a oxidação dos intermediários da reação.

As reações que ocorrem nas Células a Metanol Direto são:

Ânodo: $\mathrm{CH}_{3} \mathrm{OH}+\mathrm{H}_{2} \mathrm{O} \rightarrow \mathrm{CO}_{2}+6 \mathrm{H}^{+}+6 e^{-}$

Cátodo: $\quad 3 / 2 \mathrm{O}_{2}+6 \mathrm{H}^{+}+6 e^{-} \rightarrow 3 \mathrm{H}_{2} \mathrm{O}$

Global: $\mathrm{CH}_{3} \mathrm{OH}+3 / 2 \mathrm{O}_{2} \longrightarrow \mathrm{CO}_{2}+2 \mathrm{H}_{2} \mathrm{O}$ 
Iwasita e colaboradores têm contribuído ativamente nos estudos da eletro-oxidação do metanol usando várias técnicas e, em particular, a análise dos produtos formados [21-24]. Apesar de boa parte de seus resultados terem sido obtidos para a platina, e estes podem ser (com certas restrições) extrapolados para o sistema PtRu. Nestes estudos os produtos intermediários da oxidação do metanol geralmente são o ácido fórmico e formaldeído. Em recente estudo da oxidação do formaldeído em catalisadores de PtRu com várias composições, Iwasita e colaboradores [25, 26] sugerem não apenas rotas paralelas para a formação desses produtos, como pode ser visto na Figura 1.3, mas também diferentes mecanismos. O mecanismo LangmuirHinshelwood é proposto para oxidação com a formação de $\mathrm{CO}_{2}$, enquanto que a formação das espécies estáveis menos oxidadas é atribuída a um mecanismo Eley-Rideal "reverso".

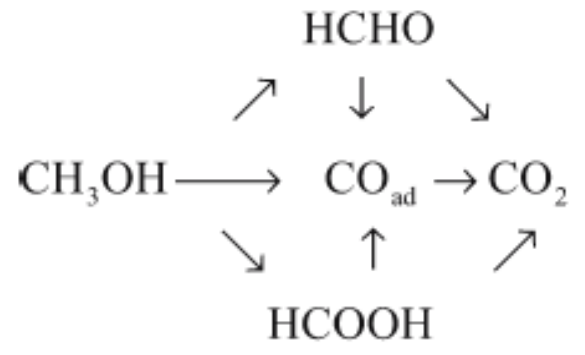

Figura 1.3 - Representação esquemático do mecanismo de oxidação do metanol, proposto por Iwasita e colaboradores.

Um dos maiores problemas para as células a combustível de metanol direto que utilizam Nafion ${ }^{\circledR}$ como eletrólito é que a mistura líquida (metanol + água) atravessa a membrana do ânodo para o cátodo, (crossover), isto ocorre devido a alta permeabilidade do metanol na membrana causando uma perda de atividade no cátodo, e o desempenho da célula cai significativamente [16]. 
O metanol também é um combustível bastante tóxico, altamente inflamável, tem um baixo ponto de ebulição $\left(65^{\circ} \mathrm{C}\right)$ e conseqüentemente estas características leva-se a buscar combustíveis alternativos ao metanol. No caso do Brasil o uso do etanol diretamente como combustível em células a combustível é de extrema importância e de interesse, pois o etanol é um combustível totalmente nacional, este é produzido em larga escala e também é menos tóxico que o metanol.

\subsection{Etanol}

O etanol é um combustível menos tóxico que o metanol, possui alta densidade energética $\left(\sim 6,7 \mathrm{kWh} \mathrm{L}^{-1}\right.$ ou $\left.\sim 8,3 \mathrm{kWh} \mathrm{kg}^{-1}\right)$, é proveniente de fontes renováveis e com contribuição zero para o efeito estufa quando completado o ciclo do $\mathrm{CO}_{2}$ na natureza $[27,28]$.

A oxidação total do etanol a $\mathrm{CO}_{2}$ corresponde a 12 elétrons por molécula.

$$
\begin{aligned}
& \text { Ânodo: } \mathrm{CH}_{3} \mathrm{CH}_{2} \mathrm{OH}+3 \mathrm{H}_{2} \mathrm{O} \longrightarrow 2 \mathrm{CO}_{2}+12 \mathrm{H}^{+}+12 e^{-} \\
& \text {Cátodo: } 3 \mathrm{O}_{2}+12 \mathrm{H}^{+}+12 e^{-} \longrightarrow 6 \mathrm{H}_{2} \mathrm{O} \\
& \text { Reação Global DEFC: } \mathrm{CH}_{3} \mathrm{CH}_{2} \mathrm{OH}+3 \mathrm{O}_{2} \longrightarrow 2 \mathrm{CO}_{2}+3 \mathrm{H}_{2} \mathrm{O} \text { (eq. 1.5) }
\end{aligned}
$$

Entretanto, esta conversão total de etanol a $\mathrm{CO}_{2}$ é o problema central na eletrocatálise deste álcool. A eletro-oxidação do etanol é mais complexa que a do metanol devido a necessidade da quebra da ligação C-C para se obter $\mathrm{CO}_{2}$ [29]. A eletro-oxidação do etanol pode seguir complicados mecanismos com diferentes etapas que geram intermediários bastante estáveis como o acetaldeído e o ácido acético, diminuindo a eficiência do sistema [30]. 
A eletro-oxidação do etanol sobre a platina ainda não está completamente elucidada. Entretanto, trabalhos da literatura [30, 31], têm proposto e relatado dois principais mecanismos de oxidação de etanol em solução ácida que podem ser resumidos no seguinte esquema de reações paralelas:

$$
\begin{aligned}
& \mathrm{CH}_{3} \mathrm{CH}_{2} \mathrm{OH} \rightarrow\left[\mathrm{CH}_{3} \mathrm{CH}_{2} \mathrm{OH}\right]_{a d s} \rightarrow \mathrm{C}_{(1) a d s}+\mathrm{C}_{(2) a d s} \rightarrow \mathrm{CO}_{a d s} \rightarrow \mathrm{CO}_{2} \\
& \mathrm{CH}_{3} \mathrm{CH}_{2} \mathrm{OH} \rightarrow\left[\mathrm{CH}_{3} \mathrm{CH}_{2} \mathrm{OH}\right]_{a d s} \rightarrow \mathrm{CH}_{3} \mathrm{CHOH} \rightarrow \mathrm{CH}_{3} \mathrm{COOH} \rightarrow \mathrm{CO}_{2} \quad \text { (eq. 1.8) }
\end{aligned}
$$

Onde $\mathrm{C}_{(1)}$ são intermediários adsorvidos com um carbono, $\mathrm{C}_{(2)}$ são intermediários adsorvidos com 2 carbonos. Iwasita e colaboradores [30, 31] têm relatado que somente $\mathrm{CO}_{2}$ é detectado na oxidação dos adsorvatos de etanol pré-adsorvido. Esta observação sugere que $\mathrm{CO}_{2}$ é formado através de um intermediário fortemente adsorvido $\left(C_{(1) \text { ads }}\right.$ e $\left.C_{(2) \text { ads }}\right)$ sobre o eletrodo, sendo que os produtos acetaldeído e ácido acético são formados através dos intermediários adsorvidos fracamente [31, 32]. 


\subsection{Catalisadores}

A natureza e a estrutura do eletrocatalisador representam um importante papel nos estudos de adsorção e na eletro-oxidação de combustíveis orgânicos, particularmente os alcoóis [27].

A curva de Volcano, publicada por Wendt [33], que relaciona o logaritmo da corrente de intercâmbio com a entalpia de adsorção de hidrogênio em diferentes superfícies metálicas, que dá uma medida quantitativa da atividade catalítica do metal, apresenta os metais do grupo da platina (Pt, Rh, Re, Ir) e os metais de transição ( $\mathrm{Ni}, \mathrm{Co}, \mathrm{Fe}, \mathrm{Cu}, \mathrm{Au}$ ) como sendo os metais com maiores valores de corrente e com entalpia de adsorção de hidrogênio moderada, demonstrando que estes metais são fortes candidatos para serem empregados como eletrocatalisadores em células a combustível. Além da platina, outros metais, tais como o ouro, ródio e o paládio foram estudados como eletrocatalisadores para reações anódicas em células a combustível. Entretanto, a platina é conhecida como melhor catalisador para as reações da célula a combustível pois, de um ponto de vista prático, apresenta a melhor atividade catalítica e estabilidade sobretudo em meio ácido [30]. Este fato viabiliza seu uso tanto na eletro-oxidação do hidrogênio quanto para redução do oxigênio. Entretanto a platina sozinha não é suficientemente ativa para a oxidação do $\mathrm{CO}_{\text {ads }}$ a $\mathrm{CO}_{2}$ em condições típicas de operação da célula a combustível alimentada diretamente por alcoóis.

Uma solução conveniente para modificar as propriedades eletrocatalíticas da platina, tornando-a mais tolerante ao CO, é adicionar à platina um segundo ou terceiro metal [27]. Muitos metais foram propostos para modificarem a platina, mas somente alguns aumentam efetivamente a atividade 
para a eletro-oxidação de alcoóis. A adição de Ru, Sn, W, Mo, Pd e Ni têm sido estudados com a finalidade de se identificar o sistema catalítico mais apropriado para eletro-oxidação direta de alcoóis [34-49]. Dentre estes eletrocatalisadores binários para oxidação de metanol e etanol, os sistemas PtRu e PtSn têm sido os mais estudados.

Entretanto a origem do aumento da atividade em catalisadores binários ainda não é completamente entendida. Há duas teorias amplamente aceitas para explicar este aumento de atividade: o mecanismo bifuncional e o efeito eletrônico.

Watanabe e colaboradores [50] postularam um mecanismo, conhecido como mecanismo bifuncional, para explicar o efeito sinergético do catalisador PtRu (a platina dissocia o metanol por quimissorção, ao passo que o rutênio ativa a água e fornece sítios preferenciais para adsorção de espécies oxigenadas, ex. $\mathrm{OH}$, a baixos potenciais).

$$
\begin{aligned}
\mathrm{Pt}+\mathrm{CH}_{3} \mathrm{OH} & \rightarrow \mathrm{Pt}-\mathrm{CO}+4 \mathrm{H}^{+}+4 e^{-} \\
\mathrm{Ru}+\mathrm{H}_{2} \mathrm{O} & \rightarrow \mathrm{Ru}-\mathrm{OH}+\mathrm{H}^{+}+e^{-}
\end{aligned}
$$

O CO adsorvido na superfície da Pt, um intermediário da reação de eletro-oxidação do metanol, pode também migrar ao longo da superfície do ânodo para reagir com o $\mathrm{Ru}-\mathrm{OH}$ :

$$
\mathrm{Pt}-\mathrm{CO}+\mathrm{Ru}-\mathrm{OH} \rightarrow \mathrm{CO}_{2}+e^{-}+\mathrm{H}^{+}+\mathrm{Pt}+\mathrm{Ru}
$$

O rutênio puro forma espécies oxigenadas na superfície em potenciais mais baixos (0,3 $\vee v s E R H)$ que a platina $(0,7 \vee v s E R H)$ [51]. Essas espécies oxigenadas adsorvidas são necessárias para completa oxidação do $\mathrm{CO}$ a $\mathrm{CO}_{2}$ [52]. Uma relação atômica entre Pt:Ru de 50:50 mostrou a melhor atividade eletrocatalítica para a oxidação de $\mathrm{CO}[53,54]$ enquanto que o teor ótimo de 
Ru para eletro-oxidação do metanol ainda é controverso na literatura, embora algumas evidências experimentais atestarem que baixos teores de $\mathrm{Ru}$ favorecem a reação de oxidação do álcool $[54,55]$.

O modelo do efeito eletrônico afirma que o papel principal do rutênio seria modificar a estrutura eletrônica da superfície da platina interagindo com a banda de condução da Pt. Presume-se que esta modificação induza um enfraquecimento da ligação $\mathrm{Pt}-\mathrm{CO}$, de forma que menos energia possa ser requerida para oxidar o CO adsorvido. Estudos de Tong e colaboradores, utilizando a técnica de ressonância magnética nuclear para investigação do CO adsorvido em superfícies de eletrodos de Pt e PtRu, mostraram que há uma alteração eletrônica significante para átomos de platina próximos a ilhas de rutênio, já os átomos de platina distantes do rutênio foram apenas afetados fracamente [56].

O catalisador Pt-Sn tem sido objeto de diversos estudos nos últimos anos, principalmente para a oxidação de metanol, $\mathrm{CO}$ e etanol. A comparação das atividades dos eletrodos, Pt, Pt-Sn e Pt-Ru para a oxidação de pequenas moléculas orgânicas mostraram que formulações Pt-Ru apresentaram uma melhor eficiência para oxidação de metanol $[57,58]$. No entanto, Pt-Sn tem um efeito bastante acentuado na oxidação de CO e etanol [59, 60].

\subsection{Métodos de Preparação de Eletrocatalisadores}

No desenvolvimento das células a combustível, apesar de avanços terem sido alcançados em vários campos, como eletrocatálise, eletrólitos, estrutura dos eletrodos, entendimento teórico da difusão do gás e da engenharia da célula a combustível, muitas questões ainda não estão 
esclarecidas. Dentre elas o efeito da preparação e da morfologia do eletrocatalisador na eficiência eletrocatalítica. Acredita-se que o método de preparação tenha uma influência importante no desempenho do catalisador [61].

O método convencional de preparação por impregnação e redução química do metal precursor não possibilita um controle satisfatório do tamanho e distribuição das nanopartículas metálicas formadas. Os métodos coloidais têm a vantagem de produzir nanopartículas metálicas pequenas, uniformes e bem distribuídas, no entanto, essas metodologias de preparação são bastante complexas e/ou apresentam alto custo o que poderia não ser economicamente viável para sínteses em larga escala [62].

O método de redução química de metais via ácido cítrico (MAC), desenvolvido neste laboratório [63], utiliza água deionizada como solvente e o ácido cítrico como agente redutor. O ácido cítrico é conhecido por ser um bom estabilizante na química coloidal, e a propriedade de estabilização das nanopartículas em solução é atribuída aos três ânions carboxílicos do ácido cítrico, e a formação de complexos com íons metálicos [64, 65]. 


\section{OBJETIVOS}

A proposta deste trabalho é a preparação de eletrocatalisadores a base de platina dispersa pelo método da redução via ácido cítrico, o qual apresenta as vantagens de ser uma metodologia simples, reprodutível e de baixo custo.

Otimizar a metodologia da redução via ácido cítrico para a obtenção de eletrocatalisadores PtRu/C e PtSn/C efetivos para a eletro-oxidação do metanol e etanol, além do estudo quanto a preparação destes catalisadores em diferentes composições atômicas.

Caracterização físico-química dos eletrocatalisadores preparados e comparação de suas respectivas atividades eletrocatalíticas tanto em estudos eletroquímicos, quanto em célula a combustível unitária alimentada diretamente com metanol ou etanol. Estes estudos têm a finalidade de encontrar os catalisadores com a composição atômica mais adequada para a oxidação de cada combustível estudado e compará-los com os catalisadores comerciais de alto desempenho da E-TEK, além de correlacionar os estudos a temperatura ambiente com os estudos em condições reais de operação. 


\section{PROCEDIMENTO EXPERIMENTAL}

Os procedimentos experimentais descritos a seguir compreendem várias etapas como: 1) a preparação dos eletrocatalisadores, 2) caracterização físicoquímica e eletroquímica dos eletrocatalisadores e 3) teste de desempenho frente a eletro-oxidação de alcoóis diretamente em célula a combustível unitária.

\subsection{Preparação dos eletrocatalisadores}

Os eletrocatalisadores platina-rutênio suportados em carbono (PtRu/C) e platina-estanho suportados em carbono $(\mathrm{PtSn} / \mathrm{C})$ foram preparados pelo método do ácido cítrico [63], com 20\% em massa de metal em lotes de 200 mg.

\subsubsection{Método da redução química por ácido cítrico}

$\mathrm{Na}$ Figura 3.1 é mostrado o fluxograma de preparação dos eletrocatalisadores $\mathrm{PtRu} / \mathrm{C}$ e $\mathrm{PtSn} / \mathrm{C}$ pelo processo da redução química via ácido cítrico (mono hidratado, Merck). Utilizou-se $\mathrm{H}_{2} \mathrm{PtCl}_{6} \cdot 6 \mathrm{H}_{2} \mathrm{O}$ (Aldrich), $\mathrm{RuCl}_{3} \cdot 1,5 \mathrm{H}_{2} \mathrm{O}$ (Aldrich) e $\mathrm{SnCl}_{2} \cdot 2 \mathrm{H}_{2} \mathrm{O}$ (Aldrich) como fontes de metais, água deionizada (18 M $\Omega \mathrm{cm}$, Milli-Q) como solvente e carbono Vulcan XC72R (Cabot) como suporte. A mistura formada é levada ao ultra-som, por 10 minutos, para uma boa homogeneização, posteriormente esta é submetida ao processo de refluxo em banho termostático à $110 \stackrel{\circ}{\circ}$ por 3 h sob agitação constante. Ao final do processo a mistura é filtrada consecutivas vezes, em papel de filtro qualitativo, porosidade $6 \mu \mathrm{m}$, (CAAL), a solução do filtrado foi separada para eventual avaliação visual de coloração e o sólido foi lavado com excesso de água destilada e posteriormente seco em estufa a $70{ }^{\circ} \mathrm{C}$ por $2 \mathrm{~h}$. Por fim, o 
catalisador é retirado do papel filtro, macerado em almofariz de ágata e armazenado em recipientes acrílicos [63].

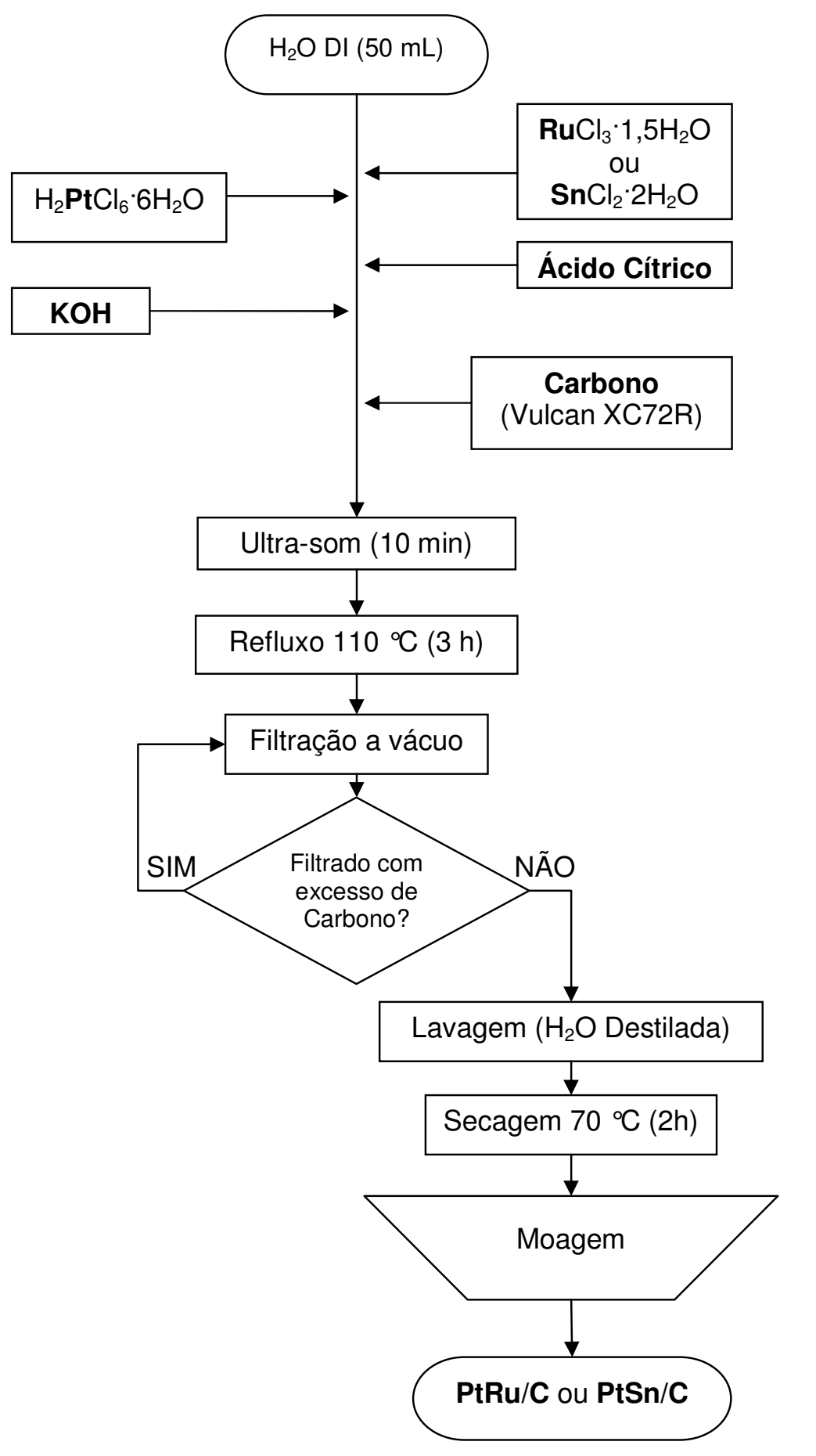

Figura 3.1 - Fluxograma do método de preparação de eletrocatalisadores via redução química por ácido cítrico [63]. 


\subsubsection{Variação da concentração do agente estabilizante}

Tendo em vista que o desempenho de eletrocatalisadores bimetálicos está relacionado ao seu processo de síntese, como a morfologia e tamanho de cristalito, foram estudados o efeito da adição do hidróxido de potássio $(\mathrm{KOH}$ $1 \mathrm{~mol} \mathrm{~L}^{-1}$ ) como estabilizante das partículas em razões molares de 1:5 e 1:10 entre metais $(\mathrm{Pt}+\mathrm{M})$ e $\mathrm{KOH}$.

\subsubsection{Variação da composição atômica entre a platina e segundo metal}

Uma vez encontrada a síntese com razão de estabilizante mais adequada, foram preparados eletrocatalisadores PtRu/C e PtSn/C em diferentes composições atômicas com o teor de Ru e Sn variando entre 10 e $50 \%$, como é mostrado no fluxograma da Figura 3.2, a fim de se eleger a melhor composição atômica para eletro-oxidação direta de alcoóis.

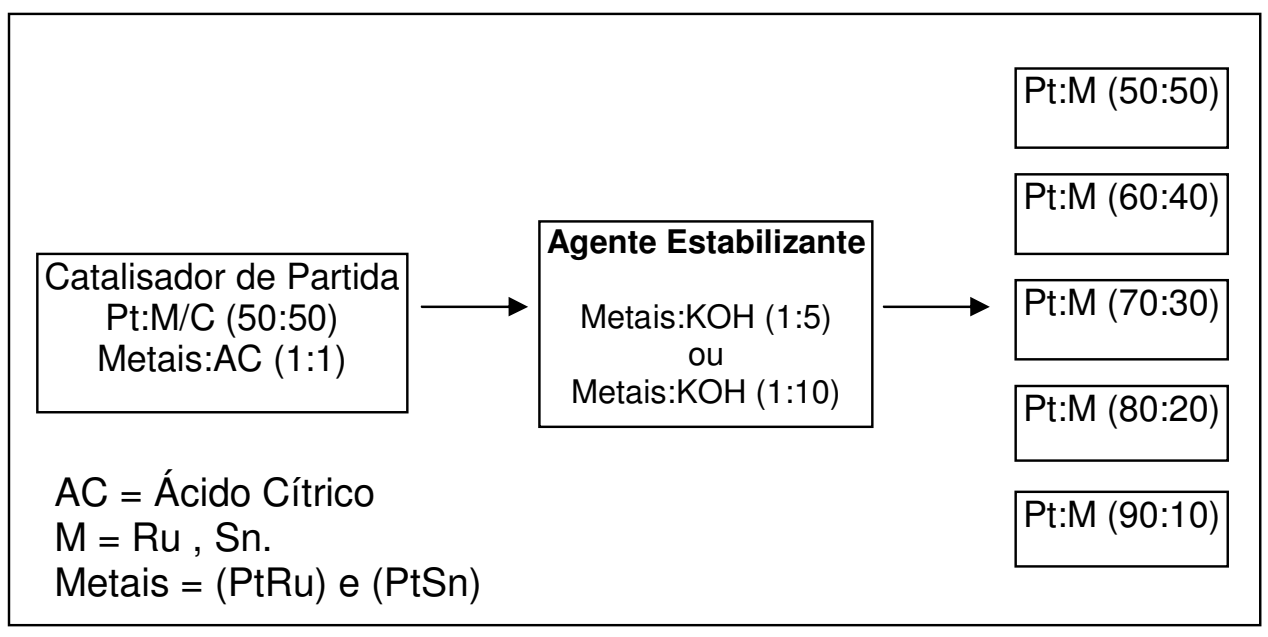

Figura 3.2 - Fluxograma da preparação dos eletrocatalisadores, onde M é o segundo metal Ru e Sn dos catalisadores PtRu/C e PtSn/C preparados. 


\subsection{Caracterização dos eletrocatalisadores}

Os eletrocatalisadores foram caracterizados por métodos físico-químicos utilizando as técnicas de espectroscopia de energia dispersiva de raios $\mathrm{X}$ (EDX) e difração de raios X (DRX). Os resultados eletroquímicos apresentados neste trabalho foram obtidos por meio da técnica de voltametria cíclica e cronoamperometria utilizando como eletrodo de trabalho o eletrodo de camada fina porosa.

Para os estudos em células a combustível alimentadas diretamente por metanol ou etanol foram selecionados quatro eletrocatalisadores, cujos desempenhos eletroquímicos verificados por voltametria cíclica e cronoamperometria destacaram-se dos demais. Estes catalisadores também foram caracterizados fisicamente utilizando-se a técnica de microscopia eletrônica de transmissão (MET).

\subsubsection{Caracterização físico-química}

\subsubsection{Espectroscopia de Energia Dispersiva de Raios X (EDX)}

A espectroscopia de energia dispersiva de raios $X(E D X)$ é uma técnica semi-quantitativa, integrada ao microscópio eletrônico, utilizada para identificar a composição elementar de uma amostra. Durante o experimento de microanálise de raios $\mathrm{X}$ a amostra é bombardeada por um feixe de elétrons $\mathrm{e}$ elétrons de camadas internas dos átomos da amostra são ejetados. Com a vacância gerada, os elétrons de maior energia tendem a ocupar o estado vacante e para isso liberam energia na forma de raios $\mathrm{X}$. A quantidade de energia liberada pelos elétrons quando vão de uma camada exterior para uma camada interior depende do nível de energia inicial e final, e como o átomo 
possui estados específicos, ele então pode ser identificado. O resultado da análise de EDX é um espectro na forma de picos que indicam os níveis de energia do salto. A integração dos picos correspondentes ao elemento desejado indica a porcentagem relativa do elemento presente na amostra [66].

O aparelho utilizado para microanálise de EDX foi o microscópio eletrônico de varredura (MEV) Philips modelo XL30 com feixe de elétrons de $20 \mathrm{KeV}$ equipado com o microanalisador EDAX modelo DX-4. Para cada experimento uma fina camada de pó do eletrocatalisador foi compactada e colada por fita dupla face sobre um porta-amostra de alumínio e introduzido no microscópio eletrônico. Foram coletados dados em quatro pontos distintos e aleatórios da amostra e o resultado final, apresentado neste trabalho, corresponde a uma média destes pontos.

\subsubsection{Difração de Raios X (DRX)}

Os padrões de difração são produzidos sempre que a luz atravessa, ou é refletida por uma estrutura periódica que apresenta um padrão que se repete regularmente. Para que o padrão de difração seja bem evidente o comprimento de onda da luz incidente deve ser aproximadamente igual a distância na qual se repete na estrutura periódica em um retículo cristalino. As distâncias entre os átomos são da ordem do comprimento de onda dos raios $\mathrm{X}$ e assim, o raio $\mathrm{X}$ é a radiação mais adequada para este propósito. Ao incidir raios $\mathrm{X}$ sobre a estrutura cristalina, seus átomos se convertem em centros osciladores e emitem sua radiação em todas as direções. Trata-se de um processo de dispersão coerente, no qual os raios, dispersos de cada átomo, se reforçam ou se anulam mutuamente, em determinadas direções do espaço, desde que as 
distâncias percorridas sejam ou não múltiplos do comprimento de onda da radiação $X$ (Lei de Bragg). Os difratômetros de raios $X$ funcionam de forma a garantir o ângulo de Bragg para a formação dos fenômenos de difração de raios $X$ (gerados pelo equipamento) através dos retículos cristalinos das amostras. O contador do equipamento mede a intensidade do feixe difratado em toda a faixa de ângulos $2 \theta$ e registra no difratograma.

As análises dos difratogramas de raios $X$ permitem a obtenção de informações quanto à estrutura cristalina dos catalisadores bem como a estimativa do tamanho médio de cristalito do catalisador através da equação de Scherrer $[67,68]$.

As medidas de difração de raios $X$ foram obtidas em um difratômetro de raios $\mathrm{X}$ da Rigaku modelo Multiflex com fonte de radiação de CuK $_{\alpha}$ $(\lambda=1,54056 \AA)$, varredura em $2 \theta$ de $20^{\circ}$ à $90^{\circ}$ com velocidade de varredura de $2^{\circ} \mathrm{min}^{-1}$. Para estes experimentos uma pequena quantidade do catalisador, cerca de $5 \mathrm{mg}$, foi compactado em um suporte de vidro que depois foi inserido no difratômetro.

Para se estimar o valor médio do diâmetro dos cristalitos do catalisador, foi realizado um ajuste de Lorentz no pico de reflexão correspondente ao plano (220) da estrutura CFC da platina e suas ligas, pois no intervalo de $2 \theta$ entre $60^{\circ}$ e $75^{\circ}$ não há contribuições de outros picos. O valor médio do diâmetro de cristalito é estimado segundo a fórmula de Scherrer [69]:

$$
d=\frac{K \cdot \lambda}{\beta \cdot \cos \theta} \quad \text { Equação de Scherrer (eq. 3.1) }
$$

Onde $d$ é o diâmetro médio das partículas em angstroms, $K$ é uma constante que depende da forma dos cristalitos, foi utilizado o valor de $K=0,9$ 
admitindo-se cristalitos esféricos, $\lambda$ é o comprimento de onda da radiação

usada, no caso do $\mathrm{Cu} \mathrm{K} \alpha, \lambda=1,54056 \AA$, segundo a literatura o valor de $\beta$ pode ser dado, na prática, apenas como a largura a meia altura, em radianos, do pico referente ao plano (220) da amostra medida [70] e $\theta$ é o ângulo de Bragg em graus para o ponto de altura máxima do pico analisado (220).

O parâmetro de rede também foi calculado utilizando-se dados da posição angular de $\theta_{\max }$ na reflexão (220) dos difratogramas [70]:

$$
a_{c f c}=\frac{\sqrt{2} \cdot \lambda}{\operatorname{sen} \theta_{\max }}
$$

\subsubsection{Microscopia Eletrônica de Transmissão (MET)}

Microscopia eletrônica utiliza feixe de elétrons para formar de imagens ampliadas de uma amostra. A principal vantagem do uso de elétrons, no lugar da luz visível, para formação de imagens, é que os elétrons podem fornecer um poder de resolução até mil vezes maior $(0,2 \mathrm{~nm})$ que os melhores e mais modernos microscópios óticos (200 nm) [71].

No caso do MET a fonte de iluminação é um feixe de elétrons que atravessa a amostra gerando uma imagem ampliada (em uma tela digital ou numa placa fotográfica) com áreas claras e escuras proporcionais densidade e espessura das diferentes regiões da amostra. O microscópio eletrônico de transmissão é alimentado por um sistema de geração de alta tensão e opera sob alto-vácuo, onde a passagem dos elétrons pela coluna do microscópio é controlada por lentes eletromagnéticas. Além do seu grande poder de resolução, o MET oferece mais duas vantagens importantes que são a 
possibilidade de observar o que existe no "interior" dos materiais e a facilidade de identificação dos detalhes da microestrutura através da técnica da difração [72].

Para os estudos de microscopia eletrônica de transmissão foi utilizado um Microscópio Eletrônico de Transmissão JEOL modelo JEM-2100 (200kV). Para a análise em MET foi preparada uma suspensão de cada catalisador em álcool isopropílico, agitada em sistema de ultra-som, uma alíquota da amostra foi depositada sobre a grade de cobre $(0,3 \mathrm{~cm}$ de diâmetro) com um filme de carbono. Estas grades de cobre eram colocadas em um porta amostra para serem visualizadas no microscópio. Em média, foram tomadas 5 micrografias para cada amostra, de forma que a coleção de dados permitisse a construção de histogramas que representassem a distribuição do tamanho de partículas. Foram medidas digitalmente cerca de 300 partículas em cada amostra para construção dos histogramas e cálculo do tamanho médio de partícula.

\subsubsection{Caracterização eletroquímica}

Para os estudos eletroquímicos utilizou-se o potenciostato/galvanostato Microquimica (modelo MQPG01, Brasil) acoplado a um microcomputador do tipo IBM-PC com software da própria Microquimica. Para todos os experimentos voltamétricos e cronoamperométricos os resultados de corrente foram normalizados por grama de Pt.

Os experimentos foram realizados em uma célula eletroquímica convencional de vidro, de um compartimento e três eletrodos. Foi utilizado como eletrólito uma solução de $0,5 \mathrm{~mol} \cdot \mathrm{L}^{-1}$ de ácido sulfúrico saturada com nitrogênio, como eletrodo de referência o eletrodo reversível de hidrogênio 
$(E R H)$, como contra eletrodo foi utilizada uma placa de platina platinizada, de área geométrica de $2,0 \mathrm{~cm}^{2}$, soldada a um fio de platina.

Para confecção do eletrodo de trabalho, contendo a camada fina porosa de catalisador, um cilindro de grafite pirolítico com base de área $0,196 \mathrm{~cm}^{2}$ foi moldado em Teflon $^{\circledR}$ de tal modo que pudesse ser adaptado a um suporte especialmente construído para se adaptar ao sistema do potenciostato. No cilindro de grafite foi feita uma cavidade $(0,3 \mathrm{~mm}$ de profundidade) para a colocação da camada ativa do catalisador disperso. Um esquema deste eletrodo é mostrado na Figura 3.3.

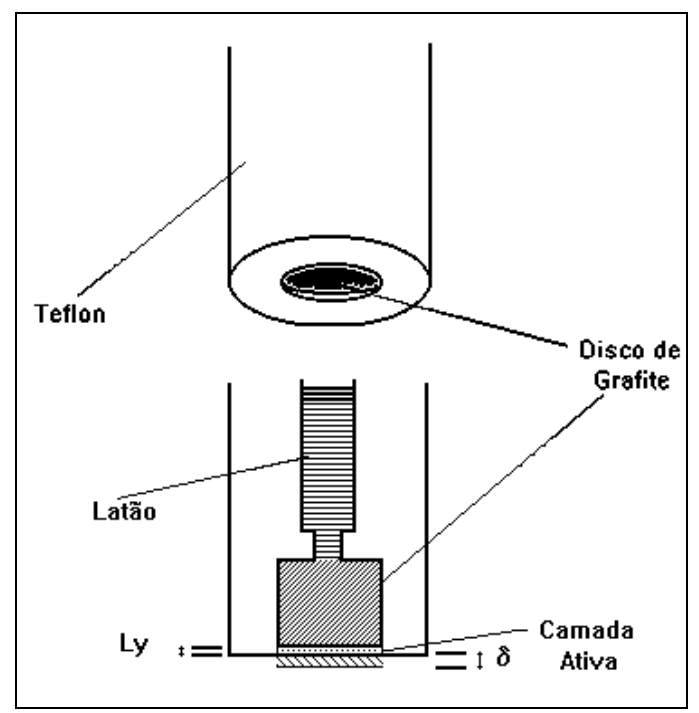

Figura 3.3 - Diagrama esquemático do eletrodo de camada fina porosa.

\subsubsection{Preparação do Eletrodo de Trabalho (eletrodo de camada fina porosa)} Uma forma simples e rápida para a avaliação de eletrocatalisadores frente às reações de oxidação é utilizar o eletrodo de camada fina porosa, o qual é preparado pela mistura de $20 \mathrm{mg}$ do catalisador com 3 gotas de solução $\operatorname{Teflon}^{\circledR}(6 \%)$ em um béquer com $50 \mathrm{~mL}$ de água deionizada sob agitação em 
um sistema de ultra-som por 10 minutos, posteriormente esta mistura é filtrada sob vácuo em filtro de membrana (Millipore HAWP04700, poro de 0,45 $\mu \mathrm{m}$ ). A mistura ainda úmida é então retirada do filtro com auxílio de uma espátula e colocada sobre a cavidade do eletrodo, fazendo-se uma leve pressão e procurando deixar a superfície a mais homogênea possível. Finalmente uma gota de água é colocada sobre a camada ativa e o eletrodo imediatamente conectado ao sistema do potenciostato e imerso na solução eletrolítica [34].

\subsubsection{Voltametria Cíclica}

Os experimentos de voltametria cíclica foram realizados na presença de eletrólito suporte $\left(0,5 \mathrm{~mol} \mathrm{~L}^{-1}\right.$ de $\left.\mathrm{H}_{2} \mathrm{SO}_{4}\right)$ na ausência e presença do álcool (metanol ou etanol na concentração de $1 \mathrm{~mol} \mathrm{~L}^{-1}$ ). Após os 40 ciclos de estabilização, os voltamogramas finais foram registrados de 0,05 à $0,8 \mathrm{~V}$ vs ERH com uma velocidade de varredura de $10 \mathrm{mV} \mathrm{s}^{-1}$. As curvas apresentadas neste trabalho são resultado da média de pelo menos três experimentos para cada eletrocatalisador.

\subsubsection{Cronoamperometria}

Os experimentos cronoamperométricos foram realizados na presença do eletrólito de $0,5 \mathrm{~mol} \mathrm{~L}^{-1}$ de $\mathrm{H}_{2} \mathrm{SO}_{4}$ mais $1 \mathrm{~mol} \mathrm{~L}^{-1}$ do álcool (metanol ou etanol). O potencial foi fixado em $500 \mathrm{mV}$ vs $\mathrm{ERH}$ durante $1800 \mathrm{~s}$. As curvas apresentadas neste trabalho são resultado da média de pelo menos três experimentos para cada eletrocatalisador. 


\subsubsection{Testes em Célula a Combustível}

Para os testes em célula unitária são necessários os tratamentos dos eletrólitos comerciais $\left(\right.$ membrana $\operatorname{Nafion}^{\circledR}$ ), bem como a utilização dos eletrocatalisadores preparados e comerciais para confecção dos eletrodos de difusão gasosa (EDG) e a montagem dos conjuntos eletrodos membrana (MEA do inglês Membrane Electrode Assemblies).

\subsubsection{Tratamento da Membrana Nafion ${ }^{\circledR}$}

Para os estudos em célula a combustível foi utilizada a membrana Nafion ${ }^{\circledR} 117$ (DuPont $^{\mathrm{TM}}$ ) como eletrólito, para todos os experimentos realizados. As membranas foram cortadas nas dimensões de $10 \mathrm{~cm} \times 10 \mathrm{~cm}$ e foram quimicamente pré-tratadas com $\mathrm{H}_{2} \mathrm{O}_{2}(3 \%)$ e com $\mathrm{H}_{2} \mathrm{SO}_{4}\left(1 \mathrm{~mol} \mathrm{~L}^{-1}\right)$ a $80{ }^{\circ} \mathrm{C}$ para remover eventuais impurezas orgânicas e minerais, respectivamente. Antes dos tratamentos químicos e entre um tratamento e outro as membranas foram imersas em $\mathrm{H}_{2} \mathrm{O}$ destilada a $80{ }^{\circ} \mathrm{C}$. A duração de cada etapa de tratamento é de uma hora. Após os tratamentos com $\mathrm{H}_{2} \mathrm{O}_{2}$ e $\mathrm{H}_{2} \mathrm{SO}_{4}$ os tratamentos em água destilada se repetiram por 3 vezes seguidas.

\subsubsection{Preparação dos eletrodos}

A camada difusora (GDL do inglês Gas Diffusion Layer) usada em todos os MEAs foi o tecido de carbono (EC-CC1-060T) tratado com PTFE (35\%) fornecido pela ElectroChem Inc.

Como o objetivo deste trabalho visa a avaliação do desempenho de eletrocatalisadores como ânodos em células a combustível, na oxidação de alcoóis, os cátodos de todos os MEAs foram fabricados mediante o método de 
aspersão a quente utilizando catalisador comercial Pt/C E-TEK (20\% de Pt em massa, lote: C0740621) e somente os ânodos foram pintados manualmente com cada eletrocatalisador preparado. Após a pintura dos pares de eletrodos, estes foram aderidos em lados opostos da membrana Nafion ${ }^{\circledR}$, para formação do $M E A$, pela técnica de prensagem a quente, a $125{ }^{\circ} \mathrm{C}$ por 2 minutos a uma

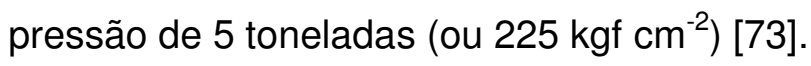

\subsubsection{1 Ânodos}

Cada ânodo do MEA foi preparado utilizando-se o tecido de carbono cortado na dimensão da área do conjunto dos canais de distribuição de gás da célula a combustível, neste caso, um quadrado de $5 \mathrm{~cm}^{2}$ juntamente com a tinta catalítica produzida com cada catalisador. Todos os ânodos (PtRu/C e $\mathrm{PtSn} / \mathrm{C}$ ) foram preparados com $1 \mathrm{mg}_{\mathrm{Pt}} \mathrm{cm}^{-2}$ e $30 \%$ de Nafion $^{\circledR}$ (dispersão $5 \%$ DE520 da DuPont ${ }^{\mathrm{TM}}$ ). Esta tinta catalítica foi aplicada manualmente sobre o tecido de carbono pela técnica da pintura por pincel até a total transferência da carga catalítica. Após a pintura o eletrodo foi colocado em estufa a $75{ }^{\circ} \mathrm{C}$ por 2 horas para secagem.

Para comparação foram produzidos eletrodos pela mesma metodologia descrita anteriormente utilizando-se eletrocatalisadores comerciais $\mathrm{Pt}_{50} \mathrm{Ru}_{50} / \mathrm{C}$ (lote: B0011117) e $\mathrm{Pt}_{75} \mathrm{Sn}_{25} / \mathrm{C}$ (lote: F0930203) ambos HP (High Performance) fornecidos pela E-TEK e com $20 \%$ de metais em massa.

\subsection{Cátodos}

Todos os cátodos de Pt/C foram preparados utilizando-se o catalisador comercial E-TEK Pt/C HP (20\% de Pt em massa, lote: C0740621) com 
$1 \mathrm{mg}$ de $\mathrm{Pt} \mathrm{cm} \mathrm{cm}^{-2}$ e $30 \%$ de Nafion ${ }^{\circledR}$. A tinta catalítica foi depositada sobre tecido de carbono, mediante a técnica de aspersão a quente, utilizando um aerógrafo manipulado por um robô $x-y$, que automatiza o processo de deposição da tinta. A carga de catalisador depositado foi controlada por gravimetria.

\subsubsection{Curvas de Polarização}

A avaliação do desempenho de uma célula a combustível se faz, geralmente, pelo estudo de sua curva de polarização, que relaciona o potencial da célula com a densidade de corrente.

As medidas de polarização foram realizadas em uma célula unitária da empresa ElectroChem com placas de grafite para distribuição de combustível do tipo serpentina ( $5 \mathrm{~cm}^{2}$ de área geométrica ativa), com o oxigênio umidificado externamente usando garrafa umidificadora de temperatura controlada aquecida a temperatura de $90{ }^{\circ} \mathrm{C}$. Foram realizados experimentos em três pressões diferentes no cátodo, de 1 bar, 2 bar e 3 bar, em todos os casos foi mantida a pressão atmosférica no ânodo. A temperatura da célula também foi ajustada em $90{ }^{\circ} \mathrm{C}$, sendo que o ânodo da célula foi alimentado com o álcool (metanol ou etanol) na concentração de $2 \mathrm{~mol} \mathrm{~L}^{-1}$ com um fluxo de aproximadamente $1 \mathrm{~mL} \mathrm{~min}{ }^{-1}$. Os testes na célula unitária foram conduzidos em um painel de testes especialmente projetado, com carga dinâmica e multímetros da empresa Electrocell, onde se mediu o potencial da célula em função da densidade de corrente, com intervalo de $10 \mathrm{~s}$ de um ponto a outro.

As curvas apresentadas neste trabalho são resultados de médias de pelo menos três ensaios. Todos os MEAs foram previamente ativados em 
testes de polarização com hidrogênio e oxigênio antes dos testes de eletrooxidação direta dos alcoóis (metanol ou etanol).

Na Figura 3.4 é mostrado um desenho esquemático dos componentes, e de como foi feita a montagem, da célula a combustível utilizada.

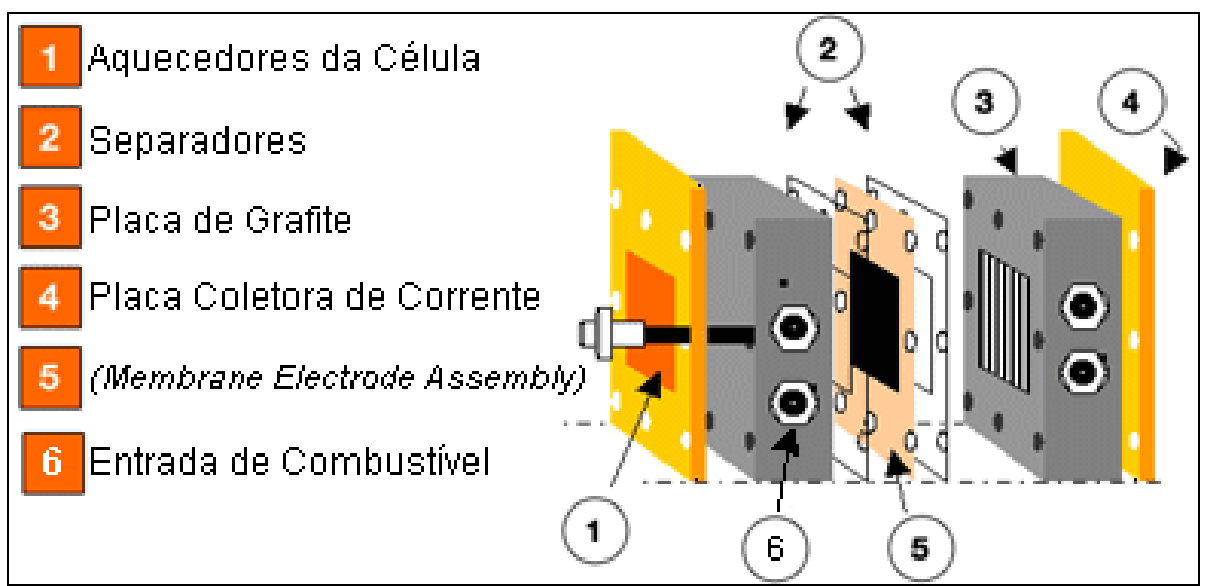

Figura 3.4 - Desenho esquemático em vista explodida dos componentes da célula a combustível tipo PEMFC utilizada, importada da empresa ElectroChem. 


\section{RESULTADOS E DISCUSSÕES}

Neste capítulo são apresentados os resultados de caracterização físicoquímica e eletroquímica dos eletrocatalisadores $\mathrm{PtRu} / \mathrm{C}$ e $\mathrm{PtSn} / \mathrm{C}$ preparados pelo método de redução via ácido cítrico.

Para a caracterização físico-química dos catalisadores foram utilizadas as técnicas de EDX, difração de raios $X$ e microscopia eletrônica de transmissão, já para os estudos eletroquímicos foram utilizadas as técnicas de voltametria cíclica e cronoamperometria. Para uma melhor comparação dos resultados foram utilizados como referências os eletrocatalisadores comerciais da E-TEK (PtRu/C (50:50) e PtSn/C (75:25)). Os eletrocatalisadores de PtRu/C (50:50) e PtSn/C (50:50) foram sintetizados em diferentes condições, onde o pH da solução foi variado, visando encontrar a condição mais favorável para a síntese destes eletrocatalisadores. Posteriormente foi realizado um estudo visando encontrar a composição otimizada de PtRu/C e PtSn/C para os estudos frente a eletro-oxidação do metanol e etanol, tanto nos estudos a temperatura ambiente quanto em condições reais de operação, ou seja, nos testes em células eletroquímicas unitárias alimentadas diretamente por álcool.

Para melhor compreensão, esse capítulo foi subdividido e, primeiramente, são apresentados todos os resultados das caracterizações para os catalisadores PtRu/C e posteriormente todos os resultados dos catalisadores $\mathrm{PtSn} / \mathrm{C}$ e por último uma comparação entre os melhores catalisadores com os catalisadores comerciais para oxidação direta de metanol e etanol. 


\subsection{Eletrocatalisadores PtRu/C}

Os eletrocatalisadores de PtRu/C foram inicialmente preparados por refluxo da solução contendo os íons metálicos de interesse, carbono como suporte das nanopartículas e ácido cítrico como agente redutor. Em trabalhos anteriores [74] já foram testados e variados alguns parâmetros de síntese para o método de redução por ácido cítrico como: temperatura, tempo de refluxo, agentes estabilizantes e concentração de ácido cítrico para produção de catalisadores PtRu/C. Tomando como base esses resultados preliminares de experimentos anteriores, o catalisador de partida $\left(\mathrm{Pt}_{50} \mathrm{Ru}_{50} / \mathrm{C}\right)$ foi preparado na razão molar de 1:1 entre metais e ácido cítrico e em três faixas de $\mathrm{pH}$ diferentes, dada pela razão molar entre os metais presentes no catalisador e o hidróxido de potássio (PtRu:KOH) de 1:0, 1:5 e 1:10.

Na Figura 4.1 são apresentados os difratogramas de raios $X$ dos três eletrocatalisadores $\mathrm{Pt}_{50} \mathrm{Ru}_{50} / \mathrm{C}$ inicialmente preparados comparados ao difratograma do catalisador $\mathrm{Pt} / \mathrm{C}$. 


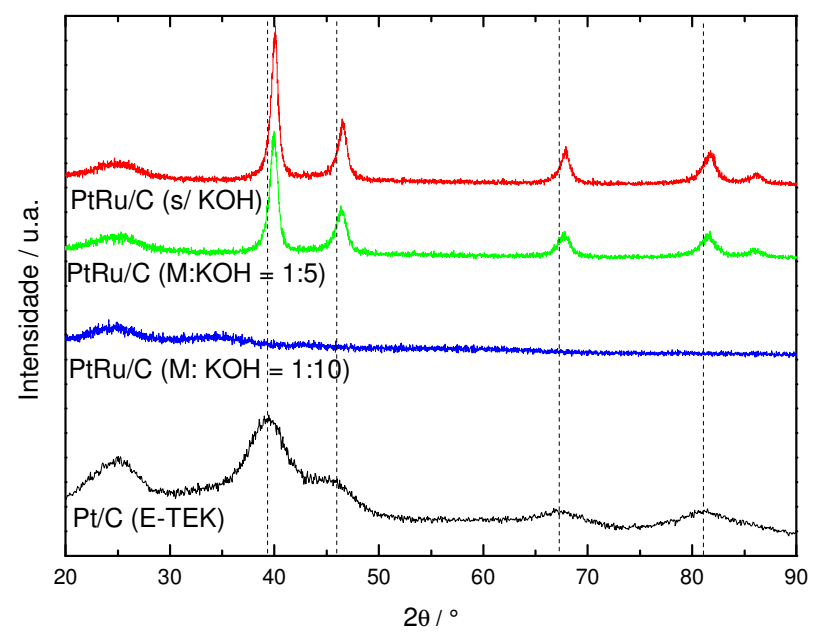

Figura 4.1 - Difratogramas de raios $\mathrm{X}$ do catalisador $\mathrm{Pt} / \mathrm{C}$ e dos eletrocatalisadores $\mathrm{Pt}_{50} \mathrm{Ru}_{50} / \mathrm{C}$ preparados via ácido cítrico em diferentes razões entre (Metais: $\mathrm{KOH}$ ).

Nos difratogramas de raios $X$ apresentados na Figura 4.1 para PtRu/C, pode-se observar os picos característicos da estrutura cúbica de face centrada da platina e suas ligas, (111), (200), (220), (311) e (222) em valores de $2 \theta$ aproximadamente iguais a $40^{\circ}, 47^{\circ}, 67^{\circ}, 82^{\circ}$ e $87^{\circ}$ respectivamente.

No caso destes sistemas PtRu/C são observados apenas os planos cristalinos típicos da estrutura cúbica de face centrada da platina ou ligas de platina, e não se observa a presença de outras fases de rutênio indicando que este material poderia apresentar certo grau de liga. Uma indicação de formação de liga poderia ser dada através dos valores de parâmetro de rede (Tabela 1). Os parâmetros de rede encontrados para os catalisadores $\mathrm{PtRu} / \mathrm{C}$ preparados foram ligeiramente menores do que o parâmetro de rede da platina suportada em carbono $(E-T E K) a_{c f c}=0,3926 \mathrm{~nm}$. Este fato está de acordo com 0 esperado, visto que, o parâmetro de rede do rutênio é menor que o da platina, indicando que sua inserção no retículo da platina ocasionou uma diminuição de toda rede e um ligeiro deslocamento dos picos para maiores valores de $2 \theta$. 
Observou-se que o catalisador $\mathrm{PtRu} / \mathrm{C}$ sintetizado na ausência de $\mathrm{KOH}$, obteve tamanho médio de cristalito estimado de aproximadamente $8 \mathrm{~nm}$, enquanto que para o catalisador preparado com a adição de estabilizante na razão molar de (1:5) entre Metais: $\mathrm{KOH}$ ocorreu uma pequena diminuição para 6,9 nm. Para o PtRu/C preparado com a razão molar de (1:10) entre Metais: $\mathrm{KOH}$ o difratograma não apresentou picos com resolução suficiente para determinação desses parâmetros. Este perfil de difratogramas é característico de catalisadores com tamanhos de cristalitos menores que $3 \mathrm{~nm}$ [75], ou com baixa cristalinidade e fases amorfas em sua composição [76, 77].

A Tabela 1 apresenta os resultados de análises da razão atômica entre Pt:Ru obtidas por EDX, parâmetros calculados a partir dos difratogramas de raios $\mathrm{X}$ e dados da síntese para os eletrocatalisadores $\mathrm{Pt}: \mathrm{Ru}(50: 50)$ onde foi variada a razão molar entre metal: $\mathrm{KOH}$.

Tabela 1 - Composição atômica entre Pt:Ru (EDX) para os catalisadores Pt:Ru ancorados em Carbono preparados com ácido cítrico variando-se a concentração de $\mathrm{KOH}$, estimativa de tamanho médio de cristalito $(d)$ e parâmetro de rede (a) calculados a partir dos difratogramas de DRX, o pH da síntese e a coloração do filtrado.

\begin{tabular}{lccccc}
\hline \multicolumn{1}{c}{ Catalisador } & $\begin{array}{c}\text { EDX } \\
\text { composição } \\
\mathbf{P t : R u ~ ( \% )}\end{array}$ & $\begin{array}{c}\boldsymbol{d} \\
(\mathbf{n m})\end{array}$ & $\begin{array}{c}\mathbf{a} \\
(\mathbf{n m})\end{array}$ & $\mathbf{p H}$ & coloração \\
\hline $\mathrm{Pt}_{50} \mathrm{Ru}_{50} / \mathrm{C}(\mathrm{s} / \mathrm{KOH})$ & $41: 59$ & 8,0 & 0,3902 & 2 & esverdeada \\
$\mathrm{Pt}_{50} \mathrm{Ru}_{50} / \mathrm{C}(\mathrm{M}: \mathrm{KOH}=1: 5)$ & $36: 64$ & 6,9 & 0,3911 & 5 & amarelada \\
$\mathrm{Pt}_{50} \mathrm{Ru}_{50} / \mathrm{C}(\mathrm{M}: \mathrm{KOH}=1: 10)$ & $48: 52$ & - & - & 11 & incolor \\
$\mathrm{Pt} / \mathrm{C}(\mathrm{E}-\mathrm{TEK})$ & - & 3,7 & 0,3926 & - & - \\
\hline
\end{tabular}

Os dados da Tabela 1, mostraram que o catalisador PtRu/C preparado apenas com ácido cítrico, sem $\mathrm{KOH}(\mathrm{pH}=2)$ apresentou um filtrado, solução, resultante após a síntese dos eletrocatalisadores, com coloração levemente esverdeada. Este resultado é um indício de que nem todo rutênio presente na preparação da amostra foi reduzido $e$ isso se refletiu no resultado da composição entre Pt:Ru dada por EDX (40:60), O catalisador preparado com a 
razão molar entre metais: $\mathrm{KOH}$ de apenas $1: 5(\mathrm{pH}=5)$, depois de filtrado e separado, mostrou uma solução com coloração amarelada, indicando que pode ter sobrado alguma quantidade de platina em solução, fato confirmado por EDX onde a composição entre $\mathrm{Pt}: \mathrm{Ru}$ foi de (36:64). O catalisador sintetizado com razão molar entre metais: $\mathrm{KOH}$ de 1:10 $(\mathrm{pH}=11)$ não mostrou nenhuma coloração para a solução do filtrado, ou seja, esta se apresentou incolor e os resultados da composição atômica entre $\mathrm{Pt:Ru}$ obtidas por EDX ficaram de acordo com a nominal de partida. Através destes resultados pode-se concluir que, para o método de redução, o pH da solução entre 2 a 5 não é satisfatório para a síntese de eletrocatalisadores $\mathrm{PtRu} / \mathrm{C}$ e somente a síntese do catalisador em valores de $\mathrm{pH}$ mais alto, aproximadamente 11 é satisfatória.

A técnica de voltametria cíclica é uma ferramenta bastante prática para se avaliar o comportamento preliminar de catalisadores frente a eletro-oxidação de alcoóis e a cronoamperometria ainda nos oferece indícios da atividade do catalisador ao longo do tempo. Neste trabalho foi utilizado como eletrodo de referência o eletrodo reversível de hidrogênio $(E R H)$ para os estudos de voltametria cíclica e cronoamperometria, sendo os valores de correntes obtidos normalizados por grama de platina.

A Figura 4.2a ilustra as varreduras anódicas obtidas a partir dos voltamogramas cíclicos para os eletrocatalisadores de PtRu/C preparados via redução por ácido cítrico. Enquanto que na Figura 4.2b são apresentados os estudos de cronoamperometria a $500 \mathrm{mV}$ por 30 minutos. Estes estudos foram realizados para a eletro-oxidação do metanol. 
a)

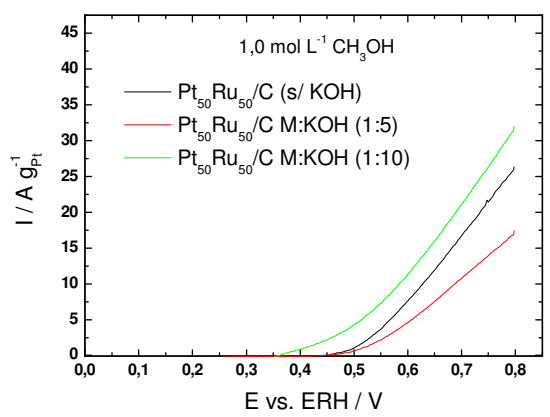

b)

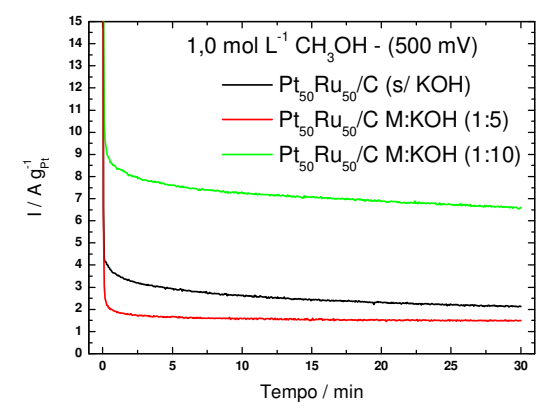

Figura 4.2 - a) Comparação dos valores de corrente para $\mathrm{Pt}_{50} \mathrm{Ru}_{50} / \mathrm{C}$ preparados por ácido cítrico variando-se a razão molar entre $\mathrm{M}: \mathrm{KOH}$ de 1:5 e 1:10 na presença de $1 \mathrm{~mol} \cdot \mathrm{L}^{-1}$ de metanol, considerando-se apenas a varredura anódica, corrigida pelo voltamograma base. b) comparação das curvas cronoamperométricas para os mesmos catalisadores com potencial fixo de $500 \mathrm{mV}$ por $30 \mathrm{~min}$.

As varreduras anódicas obtidas para os catalisadores PtRu/C, frente a eletro-oxidação do metanol em meia célula eletroquímica a temperatura ambiente, mostraram que o catalisador sintetizado com $\mathrm{pH} \cong 5$ apresentou atividade inferior ao catalisador de partida, ou seja, o catalisador sintetizado na ausência de $\mathrm{KOH}$. Entretanto, o catalisador sintetizado via ácido cítrico com razão molar entre metais: $\mathrm{KOH}$ de 1:10 $(\mathrm{pH} \cong 11)$ teve um início de oxidação em potenciais menos positivos $(\cong 0,37 \mathrm{~V})$ e ainda apresentou maiores valores de corrente em toda a faixa de potenciais estudada em relação aos demais catalisadores preparados.

O catalisador $\mathrm{PtRu} / \mathrm{C}$ sintetizado na razão molar $\mathrm{M}: \mathrm{KOH} 1: 10(\mathrm{pH} \cong 11)$ além de apresentar melhores resultados para a eletro-oxidação do metanol na região de interesse tecnológica, também apresentou maiores valores de corrente nos estudos por cronoamperometria a $500 \mathrm{mV}$, com relação aos demais catalisadores preparados. Uma constatação similar foi feita recentemente por Geng e colaboradores [78] onde estes autores estudaram a preparação de eletrocatalisadores $\mathrm{PtRu}$ com a variação do $\mathrm{pH}$ do meio 
reacional e também observaram que o melhor desempenho catalítico, para os sistemas sintetizados em valores de $\mathrm{pH}$ em torno de 12.

Na Figura 4.3 são ilustrados os resultados para a eletro-oxidação do etanol para os catalisadores PtRu/C preparados pela redução via ácido cítrico e diferentes razões entre metais: $\mathrm{KOH}$.

a)

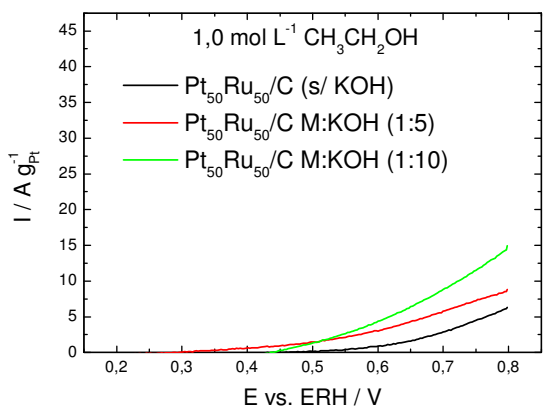

D)

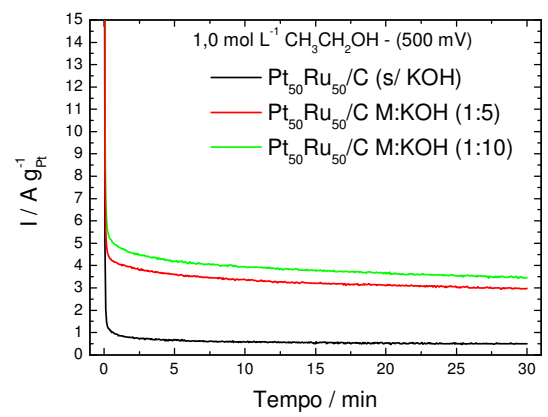

Figura 4.3 - a) Comparação dos valores de corrente para $\mathrm{Pt}_{50} \mathrm{Ru}_{50} / \mathrm{C}$ preparados por ácido cítrico variando-se a razão molar entre $\mathrm{M}: \mathrm{KOH}$ de 1:5 e 1:10 na presença de $1 \mathrm{~mol} \cdot \mathrm{L}^{-1}$ de etanol, considerando-se apenas a varredura anódica, corrigida pelo voltamograma base. b) comparação das curvas cronoamperométricas para os mesmos catalisadores com potencial fixo de $500 \mathrm{mV}$ por $30 \mathrm{~min}$.

Os estudos frente a eletro-oxidação do etanol para os catalisadores $\mathrm{PtRu} / \mathrm{C}$ mostraram coincidentemente a mesma tendência observada para 0 metanol, ou seja, o sistema PtRu/C sintetizado na razão molar M:KOH 1:10 apresentou um melhor desempenho com relação aos demais catalisadores preparados. Entretanto os valores de corrente obtidos para os sistemas PtRu/C frente a eletro-oxidação do etanol são menores do que os valores obtidos para a eletro-oxidação do metanol indicando que estes talvez sejam mais promissores para os estudos em células a combustível alimentada diretamente por metanol do que por etanol.

Após os estudos de variação da razão molar entre M:KOH para a preparação de PtRu/C, definiu-se que a razão molar M:KOH 1:10 foi a melhor 
condição para a síntese destes sistemas, pois foi a única em que se conseguiu reduzir toda a quantidade de metais presentes em solução. $O$ catalisador sintetizado nesta condição também apresentou os maiores valores de corrente em função do tempo, por isso esta condição foi a escolhida para preparação de eletrocatalisadores com diferentes composições atômicas. Pela síntese do ácido cítrico com razão molar entre metais: $\mathrm{KOH} \mathrm{1:10,} \mathrm{foram} \mathrm{preparados}$ eletrocatalisadores PtRu/C nas seguintes relações atômicas: $\mathrm{Pt}: \mathrm{Ru}(90: 10)$, $\mathrm{Pt}: R u(80: 20), \operatorname{Pt}: R u(70: 30), \operatorname{Pt}: R u(60: 40)$ e Pt:Ru(50:50). 


\subsubsection{Catalisadores PtRu preparados em diferentes composições atômicas pela melhor condição de síntese.}

$\mathrm{Na}$ Figura 4.4 são apresentados os difratogramas de raios $\mathrm{X}$ para os eletrocatalisadores PtRu/C preparados em diferentes composições atômicas, comparados aos difratogramas dos catalisadores Pt/C e PtRu/C E-TEK.

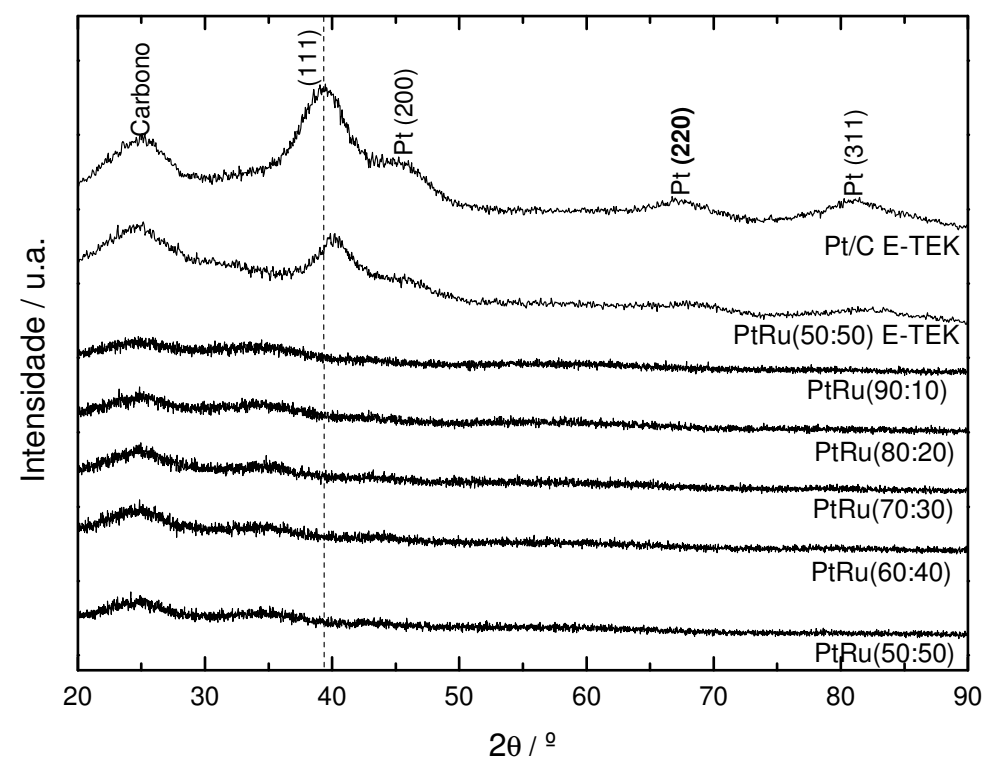

Figura 4.4 - Difratogramas de raios X dos eletrocatalisadores comerciais E-TEK e $\mathrm{PtRu} / \mathrm{C}$ preparados com diferentes teores de $\mathrm{Ru}$.

Os difratogramas dos eletrocatalisadores sintetizados não apresentaram picos definidos referentes aos planos da estrutura CFC da platina e suas ligas. Somente o pico referente ao suporte de carbono é evidenciado em todos os catalisadores. A baixa definição dos picos de reflexão nos difratogramas de raios $\mathrm{X}$ dos catalisadores preparados, podem sugerir tamanhos médios de cristalito muito pequenos, inferiores a $3 \mathrm{~nm}$ ou a presença de fases amorfas na composição dos eletrocatalisadores [76, 77, 79]. Outros autores, como Chen e colaboradores [75], quando sintetizaram nanocatalisadores em meio alcalino 
com valores de $\mathrm{pH}$ acima de 11 também observaram que o difratograma era pouco definido e os catalisadores apresentavam tamanhos de cristalitos em torno de $3 \mathrm{~nm}$. Estes autores então, comprovaram o tamanho médio de partículas por microscopia eletrônica de transmissão (MET) [75].

Nos difratogramas presentes na Figura 4.4 só foi possível calcular os parâmetros de rede e tamanho médio de cristalito para os catalisadores $\mathrm{Pt} / \mathrm{C}$ e PtRu/C comerciais da E-TEK. Para alguns dos eletrocatalisadores preparados foi possível a obtenção de micrografias de MET, as quais serão apresentadas e discutidas mais adiante.

Na Tabela 2 são apresentados os resultados de EDX e dados obtidos por DRX para os catalisadores PtRu/C preparados em diferentes composições atômicas e dos catalisadores comerciais E-TEK.

Tabela 2 - Composição atômica entre Pt:Ru (EDX) para os catalisadores preparados por ácido cítrico na razão molar entre Metais: $\mathrm{KOH}(1: 10)$ variando-se a composição atômica, dados de diâmetro e parâmetros de rede calculados por DRX e o pH da síntese e a coloração do filtrado.

\begin{tabular}{|c|c|c|c|c|c|}
\hline \multirow[b]{2}{*}{ Catalisador } & \multirow{2}{*}{$\begin{array}{c}\text { EDX } \\
\text { composição } \\
\text { Pt:Ru (\%) }\end{array}$} & \multicolumn{2}{|c|}{ DRX } & \multicolumn{2}{|r|}{ Síntese } \\
\hline & & $d(\mathrm{~nm})$ & $a(\mathrm{~nm})$ & pH & Coloração \\
\hline $\mathrm{Pt}_{50} \mathrm{Ru}_{50} / \mathrm{C}$ & $48: 52$ & - & - & 11 & incolor \\
\hline $\mathrm{Pt}_{60} \mathrm{Ru}_{40} / \mathrm{C}$ & $54: 46$ & - & - & 11 & incolor \\
\hline $\mathrm{Pt}_{70} \mathrm{Ru}_{30} / \mathrm{C}$ & $66: 34$ & - & - & 12 & incolor \\
\hline $\mathrm{Pt}_{80} \mathrm{Ru}_{20} / \mathrm{C}$ & $78: 22$ & - & - & 12 & incolor \\
\hline $\mathrm{Pt}_{90} \mathrm{Ru}_{10} / \mathrm{C}$ & $89: 11$ & - & - & 12 & incolor \\
\hline $\mathrm{Pt} / \mathrm{C}$ (E-TEK) & - & 3,7 & 0,3926 & - & - \\
\hline $\mathrm{Pt}_{50} \mathrm{Ru}_{50} / \mathrm{C}$ (E-TEK) & $46: 54$ & 3,8 & 0,3900 & - & - \\
\hline
\end{tabular}

Todos os eletrocatalisadores preparados apresentaram as composições atômicas obtidas por EDX próximas às razões nominais de partida indicando que as condições definidas anteriormente são favoráveis para a produção destes catalisadores, com diferentes teores de Ru. Foi observado que as sínteses ocorreram em valores de $\mathrm{pH}$ entre 11 e 12 e que para todos os eletrocatalisadores PtRu/C preparados a solução do filtrado, não apresentou 
nenhuma coloração. Estes resultados indicaram que a maioria dos metais presentes em solução foram reduzidos e possivelmente incorporados ao catalisador.

A fim de se obter mais informações quanto ao tamanho das nanopartículas, construiu-se histogramas da distribuição do tamanho de partículas paras os eletrocatalisadores $\mathrm{Pt}_{50} \mathrm{Ru}_{50} / \mathrm{C}$ e $\mathrm{Pt}_{80} \mathrm{Ru}_{20} / \mathrm{C}$ preparados pelo método do ácido cítrico e para o catalisador $\mathrm{Pt}_{50} \mathrm{Ru}_{50} / \mathrm{C}$ da E-TEK através das micrografias obtidas pela técnica de microscopia eletrônica de transmissão (Figura 4.5). 


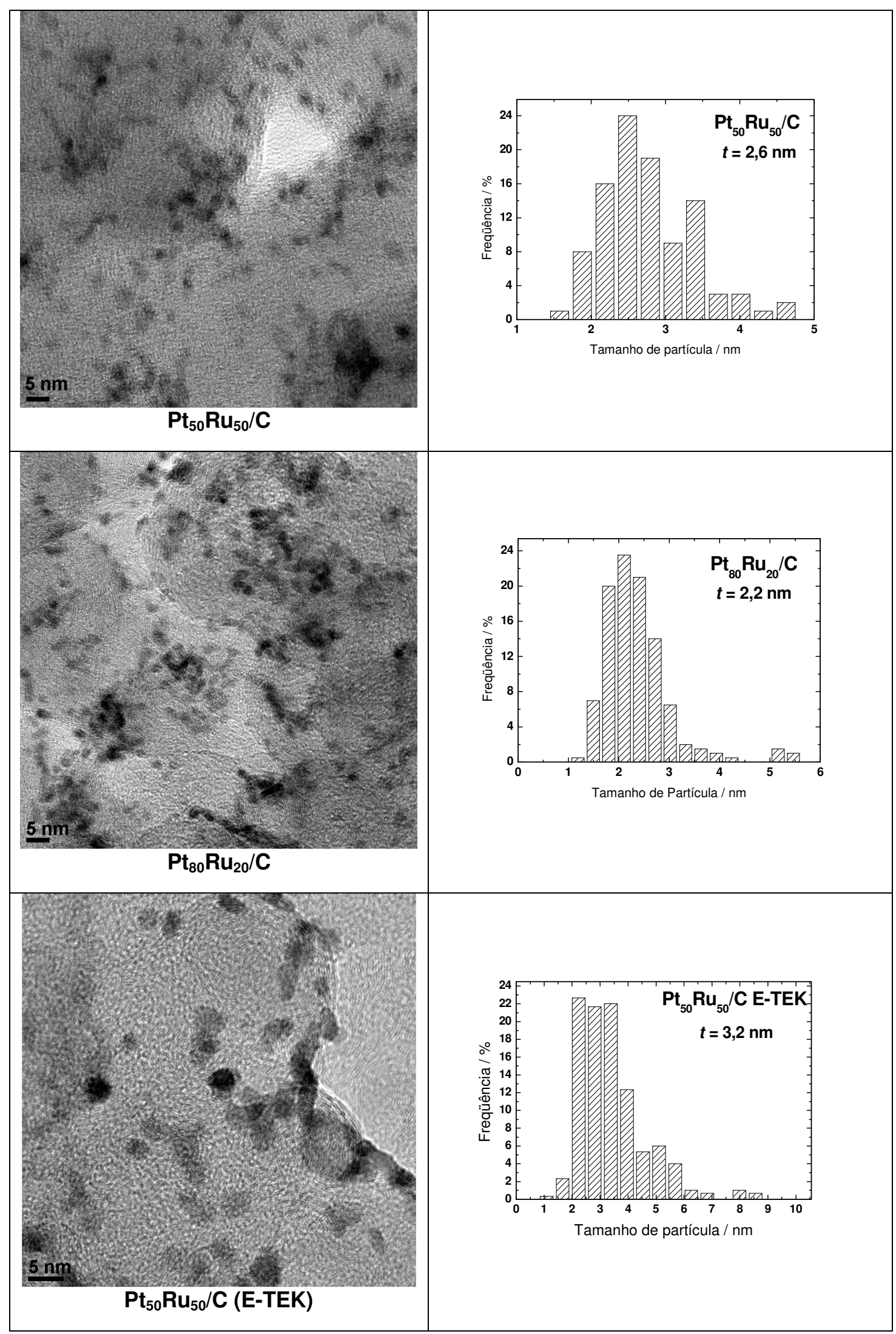

Figura 4.5 - Imagens de microscopia eletrônica de transmissão dos catalisadores $\mathrm{PtRu} / \mathrm{C}$ e seus respectivos histogramas da freqüência do tamanho de partículas. 
As micrografias de MET dos eletrocatalisadores $\mathrm{Pt}_{50} \mathrm{Ru}_{50} / \mathrm{C}$ e $\mathrm{Pt}_{80} \mathrm{Ru}_{20} / \mathrm{C}$ preparados mostraram em geral boa distribuição das nanopartículas no suporte, sendo que a maioria das nanopartículas contabilizadas apresentou tamanhos entre 1,5 a $3,5 \mathrm{~nm}$ com tamanhos médio de 2,6 nm para o $\mathrm{Pt}_{50} \mathrm{Ru}_{50} / \mathrm{C}$ e 2,2 nm para o $\mathrm{Pt}_{80} \mathrm{Ru}_{20} / \mathrm{C}$. O catalisador $\mathrm{Pt}_{50} \mathrm{Ru}_{50} / \mathrm{C}$ E-TEK também apresentou uma boa homogeneidade de distribuição das nanopartículas no suporte e tamanho médio de partícula de 3,2 nm. Os resultados das análises de microscopia eletrônica de transmissão para os eletrocatalisadores de PtRu/C mostraram que o método de preparação de catalisadores via redução por ácido cítrico foi efetivo para preparação destes sistemas, visto que foram obtidas boa homogeneidade para as partículas com tamanhos médios entre 2 e $3 \mathrm{~nm}$, os quais são considerados tamanhos otimizados para os estudos frente a eletro-oxidação de alcoóis. Entretanto, tanto os difratogramas (obtidos por DRX) quanto as micrografias (MET) não mostraram sinais de cristalinidade dos eletrocatalisadores preparados. Foram obtidos também, padrões de difração por transformada rápida de Fourier das imagens de $\mathrm{MET}$, contudo estes também não mostraram sinais de cristalinidade dos materiais preparados.

A Figura 4.6 ilustra a comparação dos valores de corrente para os catalisadores $\mathrm{PtRu} / \mathrm{C}$ preparados em diferentes composições atômicas comparados ao catalisador comercial PtRu/C E-TEK na presença de $1 \mathrm{~mol} \mathrm{~L}^{-1}$ de metanol, e das curvas cronoamperométricas com potencial fixo de $500 \mathrm{mV}$ por 30 min obtidas em experimentos com célula eletroquímica a temperatura ambiente. 
a)

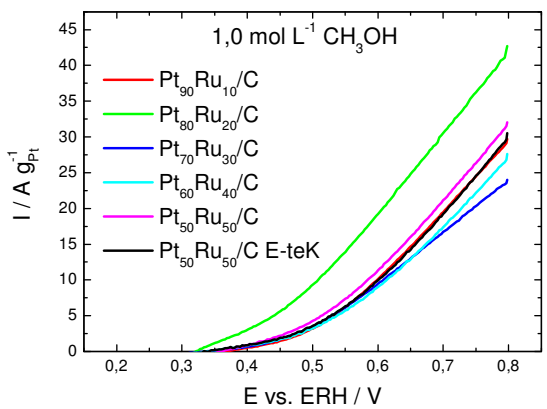

b)

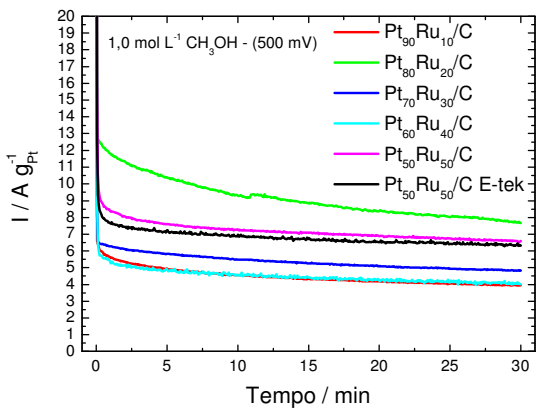

Figura 4.6 - a) Comparação dos valores de corrente para os catalisadores PtRu/C preparados por ácido cítrico nas composições atômicas entre Pt:Ru de 90:10, 80:20,

70:30, 60:40 e 50:50 e catalisador E-TEK na presença de $1 \mathrm{~mol} \cdot \mathrm{L}^{-1}$ de metanol, considerando-se apenas a varredura anódica, corrigida pelo voltamograma base e b) comparação das curvas cronoamperométricas para os mesmos catalisadores com potencial fixo de $500 \mathrm{mV}$ por $30 \mathrm{~min}$.

O catalisador $\mathrm{Pt}_{80} \mathrm{Ru}_{20} / \mathrm{C}$ apresentou o início de oxidação do metanol em menores valores de potencial e também apresentou maiores valores de corrente em toda a faixa de potencial estudada em relação aos demais catalisadores preparados. Nos resultados de cronoamperometria pode-se observar que o catalisador $\mathrm{Pt}_{80} \mathrm{Ru}_{20} / \mathrm{C}$ apresentou maiores valores de corrente que os demais catalisadores preparados para eletro-oxidação de metanol, estes resultados estão de acordo com os de voltametria cíclica. O eletrocatalisador $\mathrm{Pt}_{50} \mathrm{Ru}_{50} / \mathrm{C}$ preparado tem atividade e estabilidade similares ao catalisador $\mathrm{Pt}_{50} \mathrm{Ru}_{50} / \mathrm{C}$ E-TEK, já as demais composições preparadas apresentaram menores valores de corrente com o passar do tempo.

O melhor desempenho observado para o catalisador $\mathrm{Pt}_{80} \mathrm{Ru}_{20} / \mathrm{C}$ poderia estar associado ao possível fato de que para a oxidação completa do metanol sejam necessários três átomos de platina e um átomo de rutênio adjacente [17], estas configurações poderiam ocorrer com mais freqüências em catalisadores com baixos teores de segundo metal e estas conseqüentemente poderiam favorecer a eletro-oxidação do metanol $[54,55]$. Outro fato importante 
é que, à temperatura ambiente o metanol adsorver-se fortemente sobre sítios de platina, tendo esta um papel extremamente importante, enquanto que o rutênio fornece as espécies oxigenadas em menores potenciais com relação à platina, este mecanismo é conhecido como mecanismo bifuncional [50]. Estas observações sugerem que o método de preparação de eletrocatalisadores via redução por ácido cítrico, desenvolvido no laboratório de células a combustível do IPEN, é bastante promissor, quanto a preparação de eletrocatalisadores de PtRu/C para os estudos frente a eletro-oxidação do metanol.

Para os estudos de oxidação direta de alcoóis em célula a combustível unitária foram selecionados os catalisadores $\mathrm{Pt}_{80} \mathrm{Ru}_{20} / \mathrm{C}$ e $\mathrm{Pt}_{50} \mathrm{Ru}_{50} / \mathrm{C}$ preparados pelo método do ácido cítrico e os catalisadores comerciais $\mathrm{Pt} / \mathrm{C}$ e $\mathrm{Pt}_{50} \mathrm{Ru}_{50} / \mathrm{C}$ da E-TEK.

A Figura 4.7 ilustra as curvas de polarização obtidas frente a eletrooxidação do metanol para os catalisadores $\mathrm{Pt}_{80} \mathrm{Ru}_{20} / \mathrm{C}$ e $\mathrm{Pt}_{50} \mathrm{Ru}_{50} / \mathrm{C}$ preparados em comparação com os catalisadores comerciais da E-TEK. Estes experimentos possibilitam a avaliação do uso dos eletrocatalisadores em condições reais de operação, ou seja, os estudos foram realizados em células a combustível unitárias, de $5 \mathrm{~cm}^{2}$, alimentadas diretamente por metanol.

Os experimentos foram realizados pressurizando a saída de oxigênio do cátodo (backpressure) em três diferentes pressões absolutas: 1, 2 e 3 bar, a fim de se minimizar efeitos como o crossover do álcool e encontrar uma condição de operação mais favorável para o combustível estudado. 


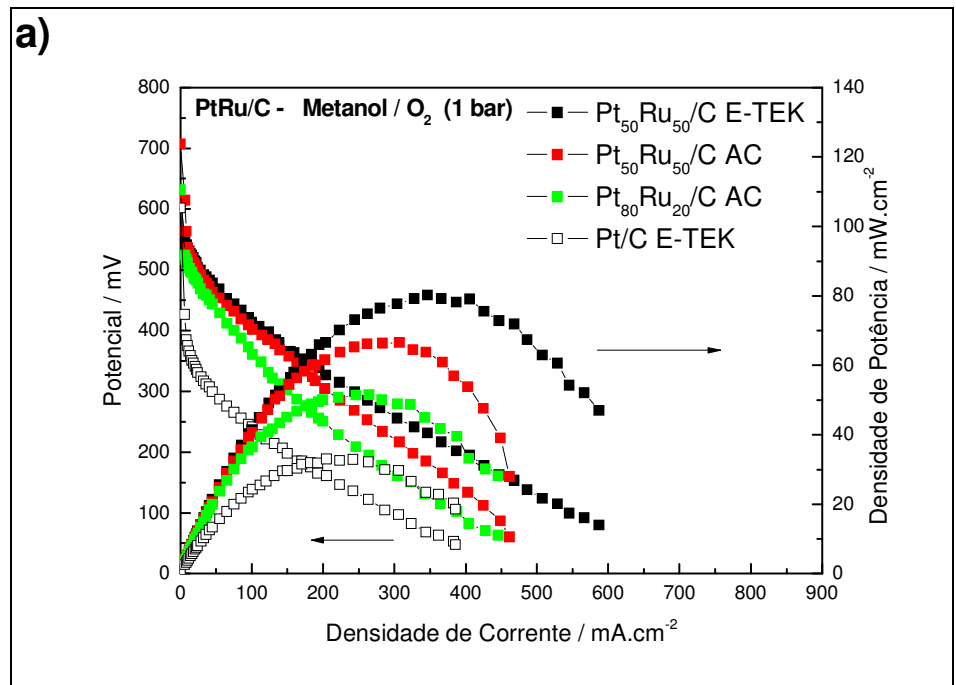

b)

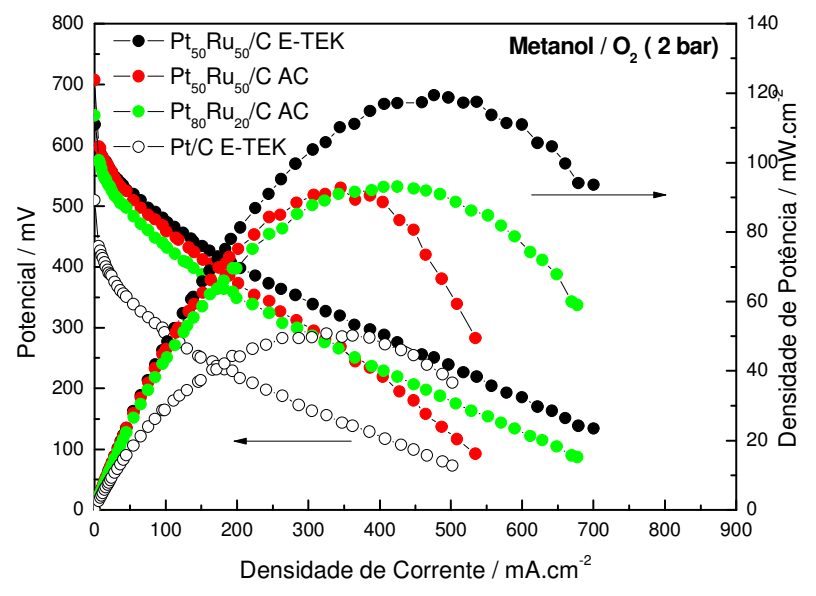

c)

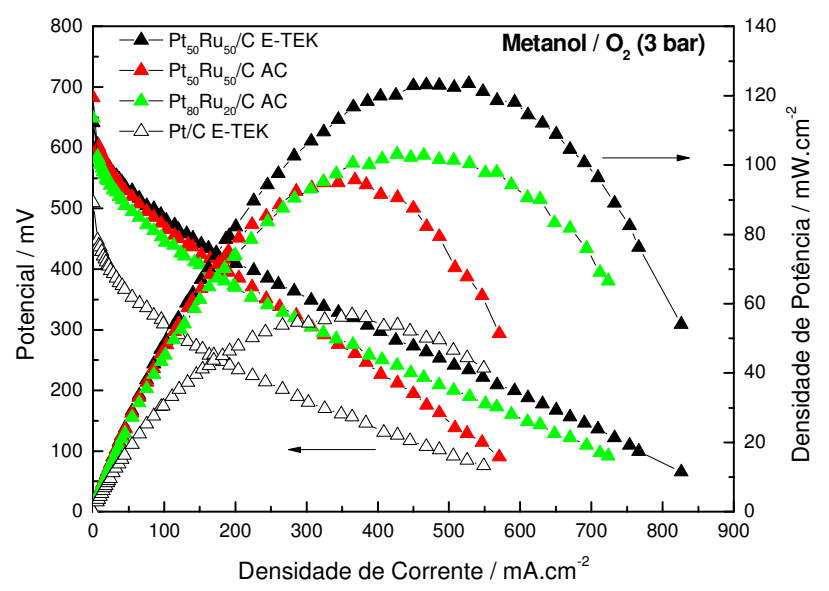

Figura 4.7 - Curvas de polarização para $\mathrm{Pt}_{50} \mathrm{Ru}_{50} / \mathrm{C}, \mathrm{Pt}_{80} \mathrm{Ru}_{20} / \mathrm{C}$ e Pt/C, $\mathrm{Pt}_{50} \mathrm{Ru}_{50} / \mathrm{C}(\mathrm{E}-$ TEK), a $90^{\circ} \mathrm{C}$, fluxo $\cong 1 \mathrm{~mL} \mathrm{~min}^{-1}$ de solução de Metanol $\left(2 \mathrm{~mol} \mathrm{~L}^{-1}\right)$, fluxo de $\mathrm{O}_{2}$ de $500 \mathrm{~mL} \mathrm{~min}{ }^{-1}$, em diferentes pressões na saída do $\mathrm{O}_{2}$ de: a) 1 bar; b) 2 bar e c) 3 bar. 
Observou-se que na a eletro-oxidação do metanol para o sistema PtRu/C ocorreu um aumento do potencial de circuito aberto, bem como um aumento global de corrente para todos os catalisadores a medida que se aumentou a pressão no oxigênio do cátodo. $O$ aumento da pressão de oxigênio pode melhorar o transporte de oxigênio à camada catalítica do cátodo, melhorando a reação de redução de oxigênio (RRO), podendo servir também como impedimento físico ao crossover de metanol do ânodo para o cátodo e podendo acelerar o descarte de água produzida no lado de cátodo [80].

Os estudos em células a combustível alimentadas por metanol a pressão

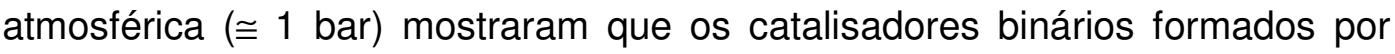
$\mathrm{Pt}+\mathrm{Ru}$, (mesmo com baixo teor de $\mathrm{Ru}, 20 \%$ ) foram mais efetivos para eletrooxidação de metanol do que o catalisador composto apenas por Pt suportada em carbono. O catalisador de $\mathrm{Pt} / \mathrm{C}$ foi rapidamente envenenado pelo metanol e apresentou menor valor de potencial de circuito aberto e conseqüentemente menores valores de corrente que os catalisadores binários PtRu tanto para a pressão de saída de oxigênio de 1 bar quanto nas pressões de 2 e 3 bar. Estes resultados comprovam o efeito benéfico da adição de um segundo metal como o rutênio ao catalisador de platina na eletro-oxidação de metanol em DMFCs.

$\mathrm{Na}$ Figura 4.7a. observa-se um melhor desempenho para o catalisador $\mathrm{Pt}_{50} \mathrm{Ru}_{50} / \mathrm{C}$ HP (High Performance) da E-TEK seguido do catalisador $\mathrm{Pt}_{50} \mathrm{Ru}_{50} / \mathrm{C}$ preparado pelo método do ácido cítrico que apresentam desempenhos semelhantes para baixas densidades de correntes até quase $200 \mathrm{~mA} \mathrm{~cm}^{-2}$. Para maiores densidades de corrente 0 catalisador $\mathrm{Pt}_{50} \mathrm{Ru}_{50} / \mathrm{C}$ E-TEK demonstra um melhor desempenho. 
Com o aumento da pressão do oxigênio no cátodo todos os catalisadores melhoram de desempenho atingindo o maior valor de potência máxima à pressão de 3 bar (Figura 4.7c). Nestas condições o catalisador $\mathrm{Pt}_{50} \mathrm{Ru}_{50} / \mathrm{C}$ HP E-TEK atingiu potência máxima de $123 \mathrm{~mW} \mathrm{~cm}^{-2}$ seguido pelos catalisadores preparados pelo método de redução do ácido cítrico $\mathrm{Pt}_{80} \mathrm{Ru}_{20} / \mathrm{C}$ $\left(103 \mathrm{~mW} \mathrm{~cm}^{-2}\right)$ e $\mathrm{Pt}_{50} \mathrm{Ru}_{50} / \mathrm{C}\left(96 \mathrm{~mW} \mathrm{~cm}^{-2}\right)$.

Os resultados obtidos em célula a combustível a $90{ }^{\circ} \mathrm{C}$ nem sempre convergem com os resultados obtidos a temperatura ambiente em meia célula eletroquímica. A explicação baseia-se no seguinte fato: enquanto que os resultados obtidos em experimentos de meia célula eletroquímica correspondem essencialmente as atividades eletrocatalíticas dos catalisadores, em uma célula a combustível unitária (DAFC) o desempenho total depende de diversos fatores, dentre os mais importantes: (i) atividade eletrocatalítica do ânodo; (ii) condutividade iônica e resistência ao crossover de álcool da membrana condutora de prótons e (iii) gerenciamento de água no lado do cátodo da célula (função principalmente do desenho dos canais de fluxo) [81]. Além disso, a diferença de temperatura entre os experimentos deve ser considerada. Estas divergências poderiam estar relacionadas ao fato de que com o aumento da temperatura, o rutênio poderia participar mais efetivamente da reação, ou seja, além de fornecer as espécies oxigenadas que são de extrema importância na eletro-oxidação do metanol, poderia também estar adsorvendo o metanol em seus sítios catalíticos, conseqüentemente uma melhor atividade para a eletro-oxidação do metanol em temperaturas mais elevadas poderia ser observada para um catalisador que tivesse uma paridade de sítios de platina e rutênio. 
Observações semelhantes às encontradas neste trabalho foram relatadas na literatura por Gasteiger e colaboradores [82], onde os autores encontraram diferentes relações atômicas ótimas entre Pt:Ru para diferentes temperaturas de operação da célula a metanol direto. Ou seja, na operação das células a temperatura de $25^{\circ} \mathrm{C}$ o catalisador $\mathrm{Pt}_{90}: \mathrm{Ru}_{10} / \mathrm{C}$ mostrou-se mais ativo, mas com o aumento da temperatura de operação da célula para $60{ }^{\circ} \mathrm{C}$ a melhor composição entre Pt:Ru, por eles encontrada, foi a (70:30). Em estudos a temperaturas de operação de célula próximas a deste trabalho $\left(\begin{array}{ll}90 & { }^{\circ} \mathrm{C}\end{array}\right)$ Gasteiger e colaboradores [83] também encontraram a composição ótima entre Pt:Ru de (50:50), que resultou numa superfície com maior paridade de sítios entre platina e rutênio.

Também foram realizados ensaios para a eletro-oxidação do etanol para os eletrocatalisadores PtRu/C preparados e o eletrocatalisador comercial da ETEK. A Figura 4.8 ilustra a comparação dos valores de corrente obtidos em ensaios eletroquímicos para os catalisadores $\mathrm{PtRu} / \mathrm{C}$ preparados por ácido cítrico nas composições atômicas entre Pt:Ru de (90:10), (80:20), (70:30), $(60: 40)$ e $(50: 50)$ e o catalisador comercial da E-TEK na presença de $1 \mathrm{~mol} \mathrm{~L}^{-1}$ de etanol, considerando-se apenas a varredura anódica, corrigida pelo voltamograma base e a comparação das curvas cronoamperométricas para os mesmos catalisadores com potencial fixo de $500 \mathrm{mV}$ por $30 \mathrm{~min}$. 
a)

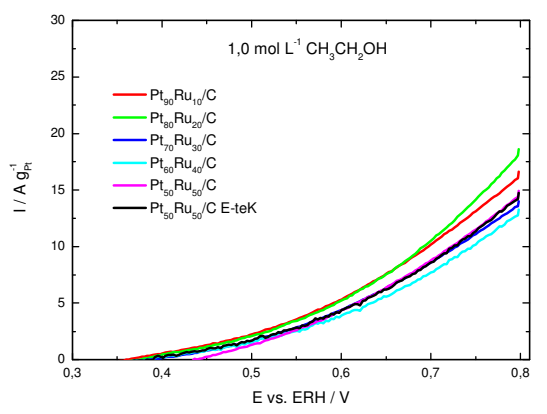

b)

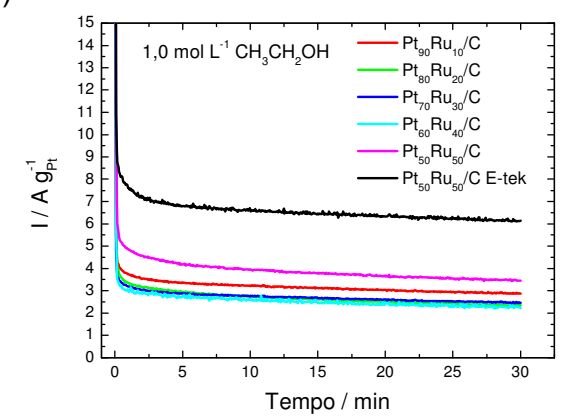

Figura 4.8 - a) Comparação dos valores de corrente para os catalisadores PtRu/C preparados por ácido cítrico nas composições atômicas entre Pt:Ru de 90:10, 80:20, 70:30, 60:40 e 50:50 e catalisador comercial da E-TEK na presença de $1 \mathrm{~mol} \cdot \mathrm{L}^{-1}$ de etanol, considerando-se apenas a varredura anódica, corrigida pelo voltamograma

base e b) comparação das curvas cronoamperométricas para os mesmos catalisadores com potencial fixo de $500 \mathrm{mV}$ por $30 \mathrm{~min}$.

Os resultados frente a eletro-oxidação do etanol obtidos a partir das varreduras anódicas mostraram desempenhos similares entre os catalisadores preparados e o catalisador comercial da E-TEK, enquanto que nos resultados de cronoamperometria o catalisador comercial da E-TEK apresentou maiores valores de corrente para eletro-oxidação do etanol quando submetidos a maiores tempo de operação. Estes resultados mostraram que, a temperatura ambiente, os eletrocatalisadores de PtRu/C preparados sofrem uma maior desativação parcial em relação ao catalisador comercial da E-TEK, quando submetidos a maiores tempos de operação. Outro fato a se considerar é o de que a eletro-oxidação da molécula de etanol também é mais complexa que a do metanol.

A Figura 4.9 ilustra os testes em células a combustível unitárias alimentadas diretamente por etanol para os catalisadores selecionados $\mathrm{Pt}_{50} \mathrm{Ru}_{50} / \mathrm{C}, \mathrm{Pt}_{80} \mathrm{Ru}_{20} / \mathrm{C}$ e os catalisadores comerciais da E-TEK em três diferentes pressões do cátodo (1,2 e 3 bar). 


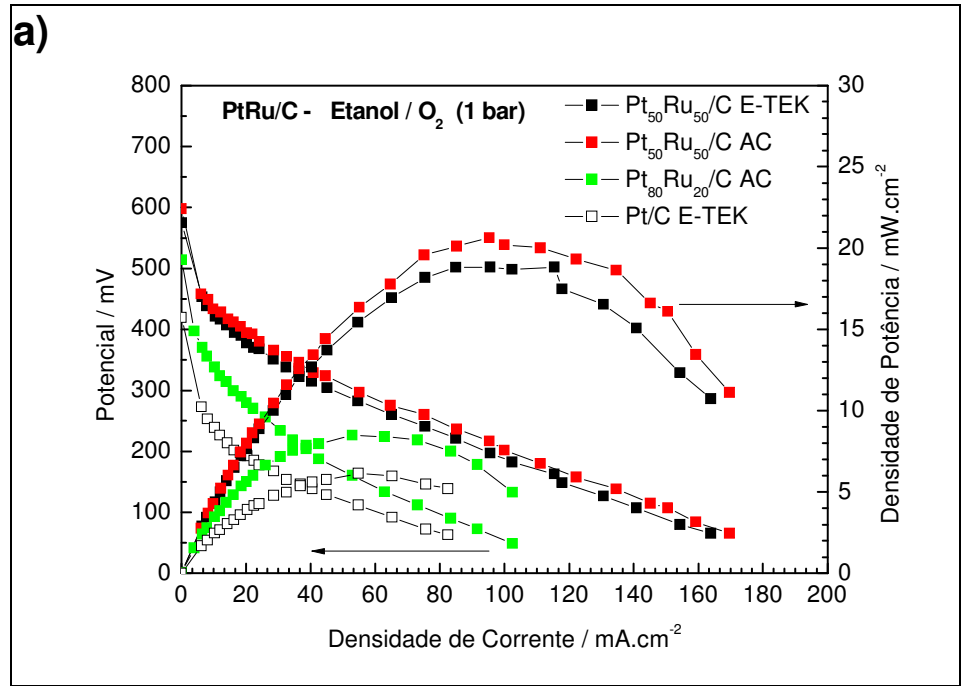

b)

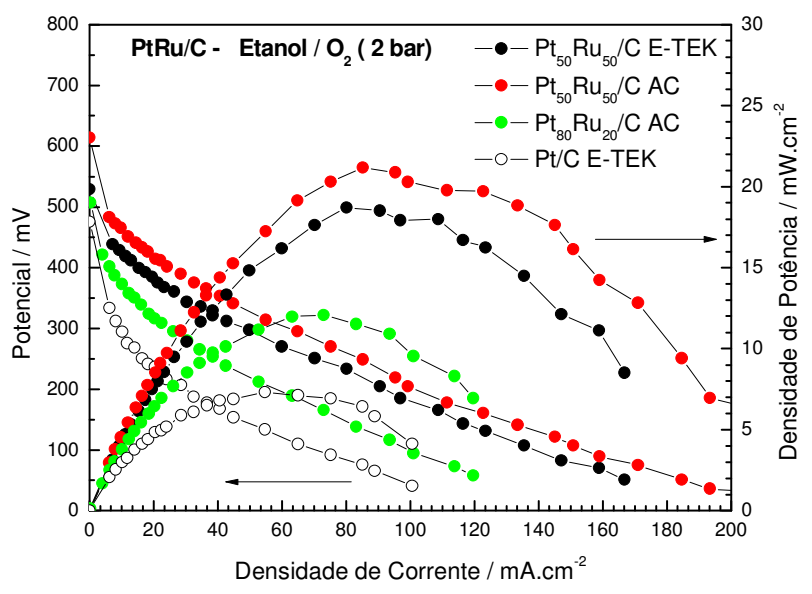

c)

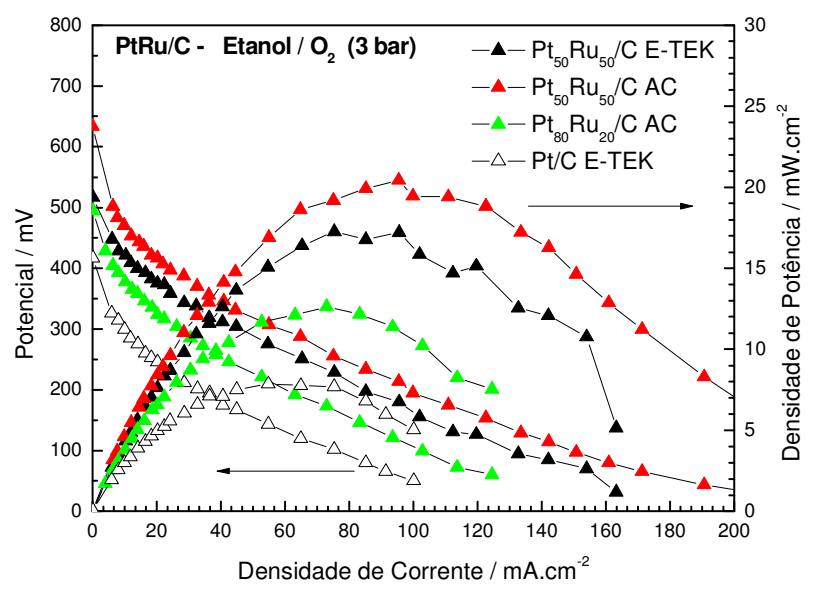

Figura 4.9 - Curvas de polarização para $\mathrm{Pt}_{50} \mathrm{Ru}_{50} / \mathrm{C}, \mathrm{Pt}_{80} \mathrm{Ru}_{20} / \mathrm{C}$ e Pt/C, $\mathrm{Pt}_{50} \mathrm{Ru}_{50} / \mathrm{C}(\mathrm{E}-$ TEK), a $90^{\circ} \mathrm{C}$, fluxo $\cong 1 \mathrm{~mL} \mathrm{~min}^{-1}$ de solução de $\mathrm{EtOH}\left(2 \mathrm{~mol} \mathrm{~L}^{-1}\right)$, fluxo de $\mathrm{O}_{2}$ de $500 \mathrm{~mL} \mathrm{~min}^{-1}$, em diferentes pressões na saída do $\mathrm{O}_{2}$ de: a) 1 bar; b) 2 bar e c) 3 bar. 
Na eletro-oxidação de etanol para os eletrocatalisadores PtRu em célula a combustível unitária, não foram observados aumentos significativos nos potenciais de circuito aberto a medida que se aumentou a pressão do cátodo, sugerindo que o fluxo de oxigênio utilizado de $500 \mathrm{~mL} \mathrm{~min}^{-1}$ (mesmo a pressão atmosférica), que foi mantido invariável para comparação com os experimentos de oxidação do metanol $[84,85]$, foi suficiente para diminuir o crossover de etanol. O crossover na célula a combustível é menor para o etanol do que para o metanol devido a menor permeabilidade do etanol através da membrana Nafion $^{\circledR}$ e também devido a cinética de eletro-oxidação de etanol em catalisador de Pt/C, do cátodo, ser mais lenta [86].

Observou-se que quanto maior o teor de platina no catalisador mais rapidamente este foi envenenado pelo etanol, apresentando assim menores valores de corrente para oxidação de etanol.

$\mathrm{Na}$ pressão de 2 bar (Figura 4.9b) o catalisador Pt/C teve o menor desempenho para eletro-oxidação do etanol $\left(7 \mathrm{~mW} \mathrm{~cm} \mathrm{~cm}^{-2}\right)$, o catalisador

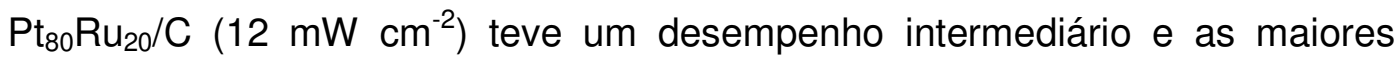
densidades de potências frente a eletro-oxidação do etanol foram dos catalisadores $\mathrm{Pt}_{50} \mathrm{Ru}_{50} / \mathrm{C}$ ETEK $\left(19 \mathrm{~mW} \mathrm{~cm}^{-2}\right)$ e $\mathrm{Pt}_{50} \mathrm{Ru}_{50} / \mathrm{C}\left(21 \mathrm{~mW} \mathrm{~cm}^{-2}\right)$ preparado pelo método do ácido cítrico. 


\subsection{Eletrocatalisadores PtSn/C}

Os eletrocatalisadores de $\mathrm{PtSn} / \mathrm{C}$ foram inicialmente preparados pelo refluxo de uma solução contendo os íons metálicos de interesse, carbono Vulcan XC72R e ácido cítrico como agente redutor. As condições de preparação também foram baseadas em estudos anteriores de preparação de PtRu pelo método do ácido cítrico [74]. Tendo como base esses resultados preliminares de experimentos anteriores, o catalisador de partida $\left(\mathrm{Pt}_{50} \mathrm{Sn}_{50} / \mathrm{C}\right)$ foi preparado na razão molar de 1:1 entre metais e ácido cítrico e em três faixas de $\mathrm{pH}$ diferentes, com razão molar entre os metais presentes no catalisador e o hidróxido de potássio (PtRu:KOH) de 1:0, 1:5 e 1:10.

Na Figura 4.10 são apresentados os difratogramas de raios $X$ dos três eletrocatalisadores $\mathrm{Pt}_{50} \mathrm{Sn}_{50} / \mathrm{C}$ inicialmente preparados comparados ao difratograma do catalisador Pt/C.

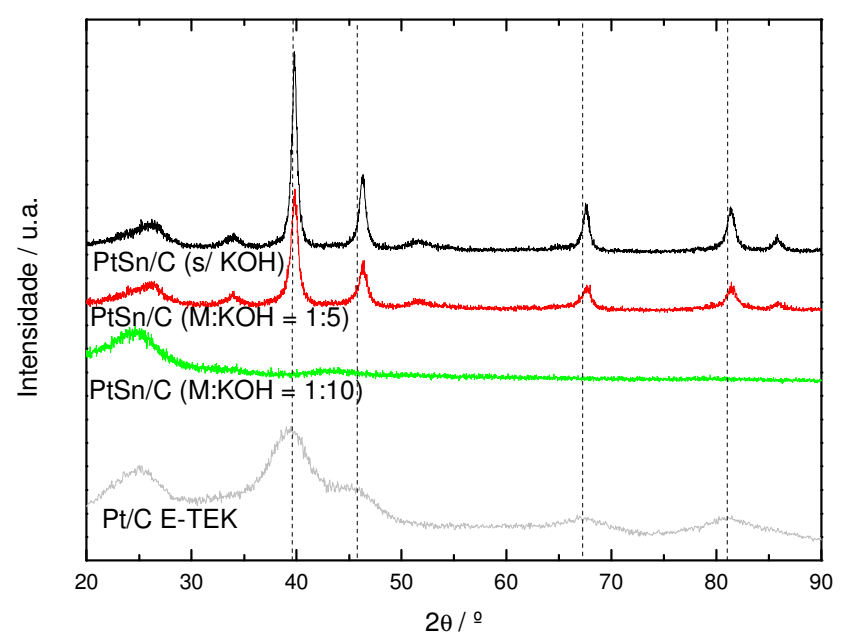

Figura 4.10 - Difratogramas de raios $\mathrm{X}$ do catalisador $\mathrm{Pt} / \mathrm{C}$ e dos eletrocatalisadores $\mathrm{Pt}_{50} \mathrm{Sn}_{50} / \mathrm{C}$ preparados via ácido cítrico em diferentes razões entre (Metais:KOH). 
Nos difratogramas de raios $\mathrm{X}$ apresentados na Figura 4.10 para $\mathrm{PtSn} / \mathrm{C}$, observam-se os picos característicos da estrutura cúbica de face centrada da platina e suas ligas, (111), (200), (220), (311) e (222) em valores de $2 \theta$ aproximadamente iguais a $40^{\circ}, 47^{\circ}, 67^{\circ}, 82^{\circ}$ e $87^{\circ}$ respectivamente.

A análise dos difratogramas dos catalisadores PtSn/C permitiu identificar além da estrutura cúbica de face centrada (cfc), típica da $\mathrm{Pt}$, duas outras reflexões em aproximadamente $34^{\circ}$ e $52^{\circ}$ que podem ser atribuídas aos planos (101) e (211) do $\mathrm{SnO}_{2}$, respectivamente, indicando que parte do $\mathrm{Sn}$, dos catalisadores preparados, encontra-se na forma de óxidos de estanho.

A presença de óxidos de estanho em materiais bimetálicos do tipo PtSn também foi verificada por Radmilovic e colaboradores [87] através de imagens de HRTEM (High Resolution Transmission Electron Microscopy). Os autores revelaram que as partículas de $\mathrm{SnO}_{2}$ se encontram sempre nas proximidades de partículas de $\mathrm{Pt}$ ou com a fase $\mathrm{Pt}_{3} \mathrm{Sn}$ e concluíram que o contato físico entre essas fases poderia ser uma das condições necessárias para o efeito promocional do $\mathrm{SnO}_{2}$ na Pt.

Os parâmetros de rede encontrados para os catalisadores PtSn/C preparados foram muito próximos ao parâmetro de rede da platina suportada em carbono (E-TEK) $a_{c f c}=0,3926 \mathrm{~nm}$ (Tabela 3). Este fato sugere que a maioria do material PtSn não se encontra na forma de liga, pois quando da formação de liga entre platina e estanho, o parâmetro de rede da nova célula unitária aumentaria com a inserção de Sn que é maior que o átomo de Pt.

Observou-se que o catalisador PtSn/C sintetizado na ausência de KOH, resultou em tamanho de cristalito estimado de aproximadamente 13,2 nm, enquanto que para o catalisador preparado com a adição de estabilizante na 
razão molar de (1:5) entre Metais: $\mathrm{KOH}$, ocorreu uma sensível diminuição para $8,5 \mathrm{~nm}$. Para o catalisador PtSn/C preparado com a razão molar de (1:10) entre Metais:KOH o difratograma não apresentou picos com resoluções suficientes para determinação desses parâmetros. Este perfil de difratogramas é característico de catalisadores amorfos ou, neste caso, quando não ocorreu a ancoragem de todos os metais no suporte de carbono.

Na Tabela 3 são apresentados os resultados de análises da razão atômica entre Pt:Sn por EDX, parâmetros calculados a partir dos difratogramas de raios X e dados da síntese para os eletrocatalisadores Pt:Sn (50:50), onde foi variada a razão molar entre metais: $\mathrm{KOH}$.

Tabela 3 - Composição atômica entre Pt:Sn (EDX) para os catalisadores Pt:Sn ancorados em Carbono preparados com ácido cítrico variando-se a concentração de $\mathrm{KOH}$, estimativa de tamanho médio de cristalito $(d)$ e parâmetro de rede $(a)$ calculados a partir dos difratogramas de DRX, o pH da síntese e a coloração do filtrado.

\begin{tabular}{lccccc}
\hline \multicolumn{1}{c}{ Catalisador } & $\begin{array}{c}\text { EDX } \\
\text { composição } \\
\mathbf{P t : S n ~ ( \% ) ~}\end{array}$ & $\boldsymbol{d}(\mathbf{n m})$ & $\boldsymbol{a}(\mathbf{n m})$ & $\mathbf{p H}$ & coloração \\
\hline $\mathrm{Pt}_{50} \mathrm{Sn}_{50} / \mathrm{C}(\mathrm{s} / \mathrm{KOH})$ & $49: 51$ & 13,2 & 0,3917 & 2 & incolor \\
$\mathrm{Pt}_{50} \mathrm{Sn}_{50} / \mathrm{C}(\mathrm{M}: \mathrm{KOH}=1: 5)$ & $50: 50$ & 8,5 & 0,3916 & 5 & incolor \\
$\mathrm{Pt}_{50} \mathrm{Sn}_{50} / \mathrm{C}(\mathrm{M}: \mathrm{KOH}=1: 10)$ & $54: 46$ & - & - & 12 & escura \\
$\mathrm{Pt} / \mathrm{C}(\mathrm{E}-\mathrm{TEK})$ & - & 3,7 & 0,3926 & - & - \\
\hline
\end{tabular}

Os dados da Tabela 3, mostraram que o catalisador $\mathrm{PtSn} / \mathrm{C}$ preparado apenas com ácido cítrico, sem $\mathrm{KOH}(\mathrm{pH}=2)$ não apresentou coloração no filtrado e a composição entre Pt:Sn obtida por EDX (49:51) está de acordo com a nominal (50:50). O catalisador $\mathrm{PtSn} / \mathrm{C}$ preparado com a razão molar entre metais: $\mathrm{KOH}$ de 1:5 $(\mathrm{pH}=5)$ também apresentou uma solução incolor após o filtrado, composição atômica dada por EDX (50:50) dentro do esperado e um menor tamanho de cristalito em relação ao catalisador s/ $\mathrm{KOH}$. Para o catalisador PtSn/C preparado com razão molar entre metais:KOH de 1:10 
$(\mathrm{pH}=12)$ não foi possível a determinação de parâmetros pelo difratograma de raio X. A avaliação pela coloração do filtrado deste catalisador mostrou que parte do material permaneceu em solução, ou seja, o mesmo apresentou uma coloração escura, mas os dados de EDX mostram que a composição atômica obtida (54:46) também se encontra próxima a nominal (50:50). Este resultado é um indício que em solução podem ter ficado quantidades equivalentes de Pt e Sn, e por isso a análise de EDX não detectou uma maior porcentagem de um único metal. É importante destacar que para maiores informações seriam necessárias análises termogravimétricas para a determinação mais precisa da quantidade de metais que permaneceram ancorados no suporte de carbono. Entretanto, estes estudos não fizeram parte do escopo deste trabalho.

Através destes resultados observou-se que para o método de redução, o pH da solução em torno de 12 não aparenta ser satisfatório para a síntese de eletrocatalisadores $\mathrm{PtSn} / \mathrm{C}$, ou seja, somente a síntese de catalisadores em $\mathrm{pH}$ mais baixo, aproximadamente 5 , se mostrou satisfatória.

$\mathrm{Na}$ Figura 4.11a são ilustradas as varreduras anódicas obtidas a partir dos voltamogramas cíclicos para os eletrocatalisadores de $\mathrm{PtSn} / \mathrm{C}$ preparados via redução por ácido cítrico, enquanto que na Figura 4.11b são apresentados os estudos de cronoamperometria a $500 \mathrm{mV}$ por 30 minutos. Os estudos foram realizados para a eletro-oxidação do metanol. 
a)

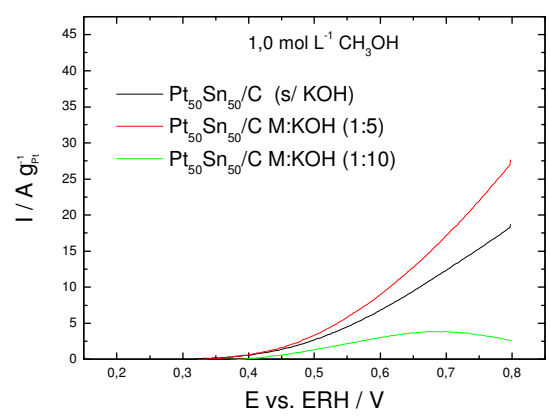

b)

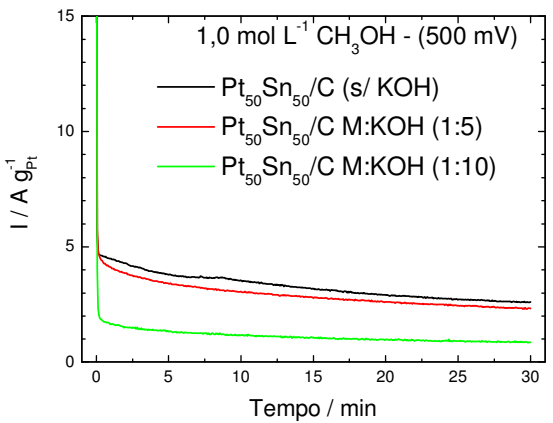

Figura 4.11 - a) Comparação dos valores de corrente para $\mathrm{Pt}_{50} \mathrm{Sn}_{50} / \mathrm{C}$ preparados por ácido cítrico variando-se a razão molar entre M:KOH de 1:5 e 1:10 na presença de $1 \mathrm{~mol} \cdot \mathrm{L}^{-1}$ de metanol, considerando-se apenas a varredura anódica, corrigida pelo voltamograma base. b) comparação das curvas cronoamperométricas para os mesmos catalisadores com potencial fixo de $500 \mathrm{mV}$ por $30 \mathrm{~min}$.

As varreduras anódicas obtidas para os catalisadores $\mathrm{PtSn} / \mathrm{C}$ frente a eletro-oxidação do metanol em meia célula eletroquímica a temperatura ambiente, mostraram que o catalisador sintetizado com $\mathrm{pH} \cong 12$ apresentou atividade inferior ao catalisador de partida, ou seja, o que não teve adição de $\mathrm{KOH}$. Entretanto o catalisador sintetizado via ácido cítrico com razão molar entre metais: $\mathrm{KOH}$ de $1: 5(\mathrm{pH} \cong 5)$ apresentou valores de corrente similares ao catalisador de partida em toda a faixa de potenciais estudada.

Os eletrocatalisadores $\mathrm{PtSn} / \mathrm{C}$, sintetizados na ausência de $\mathrm{KOH}(\mathrm{pH}=2)$ e o catalisador na razão molar entre metais: $\mathrm{KOH}$ de $1: 5(\mathrm{pH}=5)$, também apresentaram maiores valores de corrente com 0 tempo por cronoamperometria a $500 \mathrm{mV}$, com relação ao catalisador preparado com maior concentração de $\mathrm{KOH}(\mathrm{pH}=12)$.

Na Figura 4.12 são mostrados os resultados para a eletro-oxidação do etanol para os catalisadores $\mathrm{PtSn/C} \mathrm{preparados} \mathrm{pela} \mathrm{redução} \mathrm{via} \mathrm{ácido} \mathrm{cítrico} \mathrm{e}$ diferentes razões entre metais: $\mathrm{KOH}$. 
a)

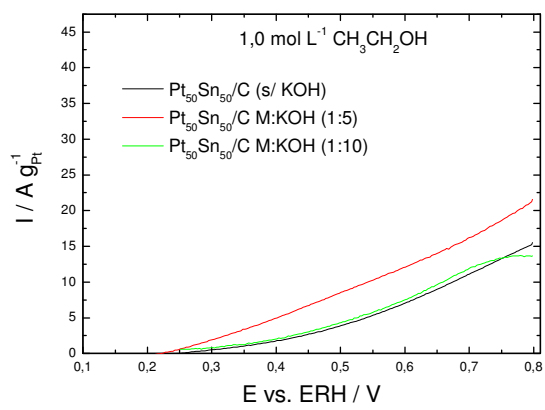

b)

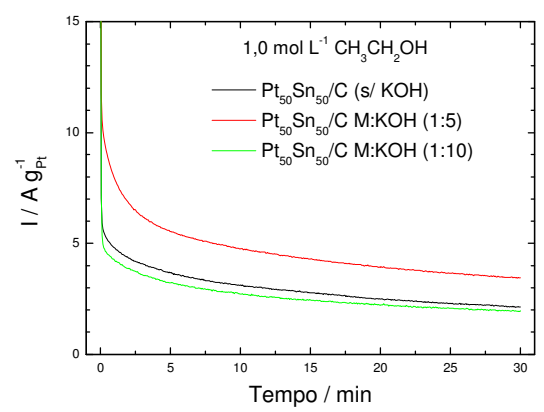

Figura 4.12 - a) Comparação dos valores de corrente para $\mathrm{Pt}_{50} \mathrm{Sn}_{50} / \mathrm{C}$ preparados por ácido cítrico variando-se a razão molar entre M:KOH de 1:5 e 1:10 na presença de $1 \mathrm{~mol} \cdot \mathrm{L}^{-1}$ de etanol, considerando-se apenas a varredura anódica, corrigida pelo voltamograma base. b) comparação das curvas cronoamperométricas para os mesmos catalisadores com potencial fixo de $500 \mathrm{mV}$ por $30 \mathrm{~min}$.

Observou-se mais acentuadamente o melhor desempenho catalítico do catalisador PtSn/C preparado na razão molar M:KOH 1:5 $(\mathrm{pH}=5)$ para a eletrooxidação do etanol em meia célula eletroquímica a temperatura ambiente. Os demais catalisadores preparados, em $\mathrm{pH}=2$ e $\mathrm{pH}=12$, apresentaram desempenhos semelhantes, mas inferiores ao catalisador sintetizado em $\mathrm{pH}=5$. O aumento da relação de Metais: $\mathrm{KOH}$ para 1:10 $(\mathrm{pH}=12)$ não resultou em uma melhora de desempenho para a eletro-oxidação de alcoóis. Este comportamento pode estar relacionado ao fato de que nestas condições nem todo metal presente em solução foi reduzido. Este fenômeno pode resultar na menor atividade observada para o eletrocatalisador. A faixa de $\mathrm{pH}$ otimizada observada ( $\mathrm{pH}$ de 2 a 5) está de acordo com a encontrada na literatura, onde Jiang e colaboradores [88] recentemente também observaram que baixos valores de $\mathrm{pH}$ foram ideais para síntese de catalisadores $\mathrm{PtSnO}_{\mathrm{x}}$. Os autores observaram que com o aumento do pH de 2 até 6 ocorreu uma diminuição do tamanho médio de partícula de $12 \mathrm{~nm}$ para $6 \mathrm{~nm}$, respectivamente. Entretanto, os autores ainda relatam que, para valores de pH acima de 7 não foi possível ancorar todo o estanho no suporte. 
Os resultados com a técnica de cronoamperometria para o catalisador $\mathrm{PtSn} / \mathrm{C}$ sintetizado em $\mathrm{pH}=5$ mostrou valores de correntes semelhantes para a oxidação do metanol e do etanol, sugerindo que este possa ser um promissor catalisador para os dois tipos de combustíveis.

Após os estudos quanto a variação da razão molar entre M:KOH para a preparação de $\mathrm{PtSn} / \mathrm{C}$, definiu-se que a razão molar M:KOH 1:5 foi a melhor condição para a síntese destes sistemas, pois apresentou a composição de metais de acordo com a nominal, um menor tamanho de cristalito (conseqüentemente uma maior área superficial) e apresentou melhor desempenho na eletro-oxidação de etanol em meia célula eletroquímica. Por estes motivos esta condição de síntese foi escolhida para preparação dos eletrocatalisadores, onde foram preparados catalisadores com diferentes composições atômicas.

Através da síntese do ácido cítrico com razão molar entre metais: $\mathrm{KOH}$ 1:5, foram preparados eletrocatalisadores $\mathrm{PtSn} / \mathrm{C}$ nas seguintes relações atômicas: Pt:Sn(90:10), Pt:Sn(80:20), Pt:Sn(70:30), Pt:Sn(60:40) e Pt:Sn(50:50). 


\subsubsection{Catalisadores PtSn preparados em diferentes composições atômicas pela melhor condição de síntese.}

$\mathrm{Na}$ Figura 4.13 são apresentados os difratogramas de raios $X$ para os eletrocatalisadores PtSn/C preparados em diferentes composições atômicas, comparados aos difratogramas dos catalisadores $\mathrm{Pt} / \mathrm{C}$ e $\mathrm{Pt}_{75} \mathrm{Sn}_{25} / \mathrm{C}$ E-TEK.

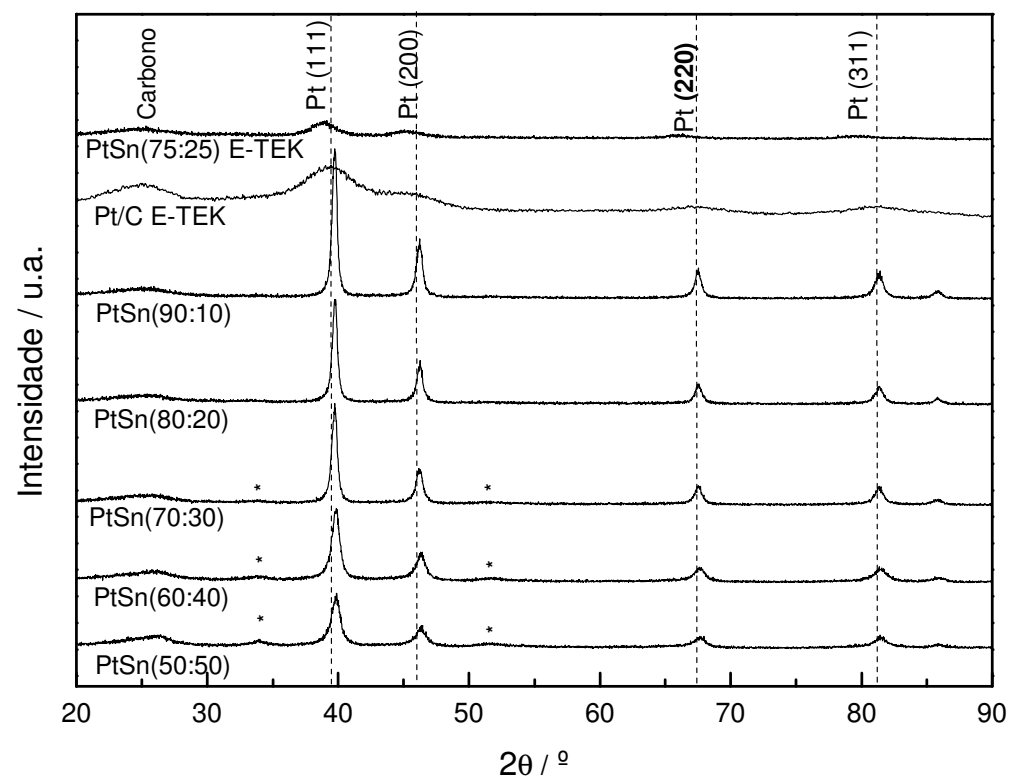

Figura 4.13 - Difratogramas de raios X dos catalisadores comerciais E-TEK e PtSn/C preparados com diferentes teores de Sn.

Nos difratogramas de raios $X$ apresentados na Figura 4.13 foram observados os picos de reflexão dos planos característicos da estrutura CFC, da platina e ligas de platina, (111), (200), (220), (311) e (222) em valores de $2 \theta$ aproximadamente iguais a $40^{\circ}, 47^{\circ}, 67^{\circ}, 82^{\circ}$ e $87^{\circ}$ respectivamente, para os sistemas PtSn/C preparados em diferentes composições atômicas, e também para os eletrocatalisadores comerciais da E-TEK.

Além das reflexões principais referentes à estrutura CFC, pode-se observar a medida que a composição de Sn aumenta no catalisador (mais 
evidente nos eletrocatalisadores de $\mathrm{Pt}_{70} \mathrm{Sn}_{30} / \mathrm{C}, \mathrm{Pt}_{60} \mathrm{Sn}_{40} / \mathrm{C}$ e $\mathrm{Pt}_{50} \mathrm{Sn}_{50} / \mathrm{C}$ ) aumenta-se a intensidade das duas outras reflexões em aproximadamente $34^{\circ}$ e $52^{\circ}$ que podem ser atribuídas respectivamente aos planos (101) e (211) do $\mathrm{SnO}_{2}$, indicando que parte do $\mathrm{Sn}$ encontra-se na forma de óxidos de estanho. Este aumento da intensidade dos planos de reflexão referentes aos ângulos $34^{\circ}$ e $52^{\circ}$ é um indício de que maiores quantidades de óxidos são formados com o aumento do teor de estanho adicionado aos eletrocatalisadores de $\mathrm{PtSn} / \mathrm{C}$. Estes resultados são bastante interessantes, visto que na literatura alguns trabalhos têm mostrado que a formação de óxidos na superfície do catalisador, em certa extensão, poderia facilitar as reações de oxidação de metanol e etanol $[89,95]$.

Na Tabela 4 são apresentados os resultados de EDX e dados obtidos por DRX para os catalisadores PtSn/C preparados em diferentes composições atômicas e dos catalisadores comerciais E-TEK.

Tabela 4 - Composição atômica entre Pt:Sn (EDX) para os catalisadores preparados por ácido cítrico na razão molar entre Metais: $\mathrm{KOH}(1: 5)$ variando-se a composição atômica, dados de diâmetro e parâmetros de rede calculados por DRX e o pH da síntese e a coloração do filtrado.

\begin{tabular}{|c|c|c|c|c|c|}
\hline \multirow[b]{2}{*}{ Catalisador } & \multirow{2}{*}{$\begin{array}{c}\text { EDX } \\
\text { composição } \\
\text { Pt:Sn (\%) }\end{array}$} & \multicolumn{2}{|c|}{ DRX } & \multicolumn{2}{|r|}{ Síntese } \\
\hline & & $d(\mathrm{~nm})$ & $a(\mathrm{~nm})$ & $\mathrm{pH}$ & Coloração \\
\hline $\mathrm{Pt}_{50} \mathrm{Sn}_{50} / \mathrm{C}$ & $50: 50$ & 8,5 & 0,3916 & 5 & incolor \\
\hline $\mathrm{Pt}_{60} \mathrm{Sn}_{40} / \mathrm{C}$ & $62: 38$ & 8,7 & 0,3916 & 5 & incolor \\
\hline $\mathrm{Pt}_{70} \mathrm{Sn}_{30} / \mathrm{C}$ & $69: 31$ & 13,4 & 0,3922 & 5 & incolor \\
\hline $\mathrm{Pt}_{80} \mathrm{Sn}_{20} / \mathrm{C}$ & $80: 20$ & 15,0 & 0,3921 & 5 & incolor \\
\hline $\mathrm{Pt}_{90} \mathrm{Sn}_{10} / \mathrm{C}$ & $84: 16$ & 15,9 & 0,3920 & 5 & incolor \\
\hline Pt/C E-TEK & - & 3,7 & 0,3926 & - & - \\
\hline $\mathrm{Pt}_{75} \mathrm{Sn}_{25} / \mathrm{C}$ E-TEK & $70: 30$ & 3,8 & 0,4002 & - & - \\
\hline
\end{tabular}

Todos os eletrocatalisadores preparados apresentam as razões atômicas obtidas por EDX em boa conformidade com as razões atômicas nominais de partida indicando que a condição de síntese escolhida foi favorável 
para a produção de catalisadores $\mathrm{PtSn/C}$ preparados com diferentes teores de estanho. Foi observado que nestas condições de sínteses os valores de pH foi igual a 5 para todos os eletrocatalisadores de PtSn/C preparados e a solução do filtrado, não apresentou nenhuma coloração. Estes resultados indicaram que a maioria dos metais presentes em solução foram reduzidos e incorporados ao catalisador.

Para os catalisadores de PtSn/C foi possível determinar os tamanhos médios dos cristalitos além do parâmetro de rede de cada catalisador, já que os picos de reflexão encontram-se mais definidos que no caso dos sistemas PtRu/C preparados. O catalisador $\mathrm{Pt}_{90} \mathrm{Sn}_{10} / \mathrm{C}$ obteve tamanho médio de cristalito de $15,9 \mathrm{~nm}$ e com o aumento do teor de Sn nos catalisadores houve diminuição do tamanho médio de cristalito chegando a $8,5 \mathrm{~nm}$ para 0 catalisador $\mathrm{Pt}_{50} \mathrm{Sn}_{50} / \mathrm{C}$.

A fim de se obter mais informações com relação ao tamanho das nanopartículas dos eletrocatalisadores $\mathrm{Pt}_{50} \mathrm{Sn}_{50} / \mathrm{C}$ e $\mathrm{Pt}_{60} \mathrm{Sn}_{40} / \mathrm{C}$ preparados pelo método do ácido cítrico e do catalisador $\mathrm{Pt}_{75} \mathrm{Sn}_{25} / \mathrm{C}$ da E-TEK, construiu-se os histogramas de distribuição do tamanho de partículas obtidos, através das micrografias de microscopia eletrônica de transmissão (Figura 4.14). 


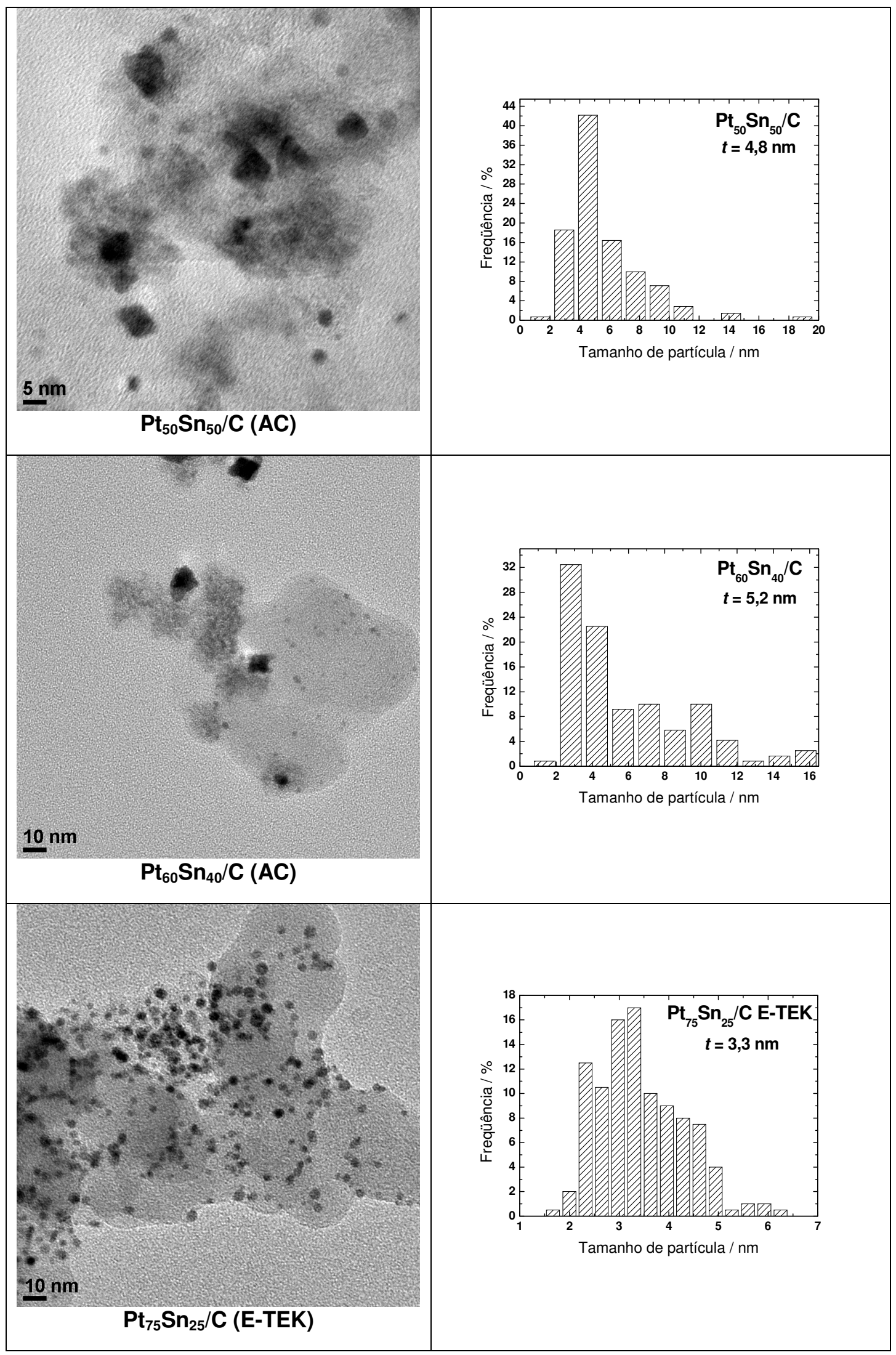

Figura 4.14 - Imagens de microscopia eletrônica de transmissão dos catalisadores $\mathrm{PtSn} / \mathrm{C}$ e seus respectivos histogramas da freqüência do tamanho de partículas. 
As micrografias de MET para os eletrocatalisadores $\mathrm{Pt}_{50} \mathrm{Sn}_{50} / \mathrm{C}$ $(\mathrm{t} \cong 4,8 \mathrm{~nm})$ e $\mathrm{Pt}_{60} \mathrm{Sn}_{40} / \mathrm{C}(\mathrm{t} \cong 5,2 \mathrm{~nm})$ preparados, mostraram uma ampla faixa de distribuição de nanopartículas no suporte de carbono (de 2 a 12 nm), enquanto que para o catalisador $\mathrm{Pt}_{75} \mathrm{Sn}_{25} / \mathrm{C}$ E-TEK ( $\left.\cong 3,3 \mathrm{~nm}\right)$ a faixa foi bem menor e a maioria das partículas encontram-se mais homogêneas e com tamanhos entre 2 a $6 \mathrm{~nm}$.

Estes resultados de MET para os eletrocatalisadores de $\mathrm{PtSn} / \mathrm{C}$ sugerem que o método de preparação de catalisadores via redução por ácido cítrico ainda pode ser aperfeiçoado para a obtenção de nanopartículas com tamanhos menores e uma melhor homogeneidade, o que poderia melhorar ainda mais a atividade eletrocatalítica dos eletrocatalisadores $\mathrm{PtSn} / \mathrm{C}$ preparados por esta metodologia.

Na Figura 4.15 são mostrados os resultados para a eletro-oxidação do metanol em meia célula eletroquímica para os catalisadores $\mathrm{PtSn} / \mathrm{C}$ preparados em diferentes composições atômicas em comparação ao o catalisador $\mathrm{Pt}_{75} \mathrm{Sn}_{25} / \mathrm{C}$ comercial da E-TEK.

a)

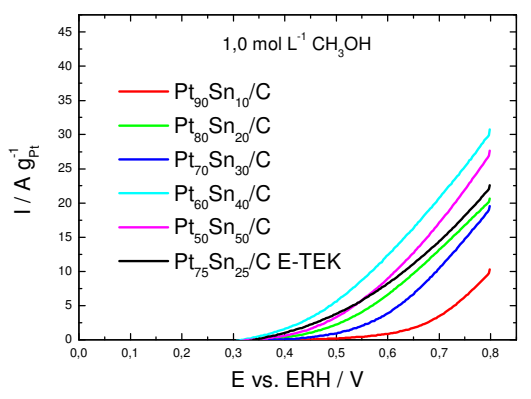

b)

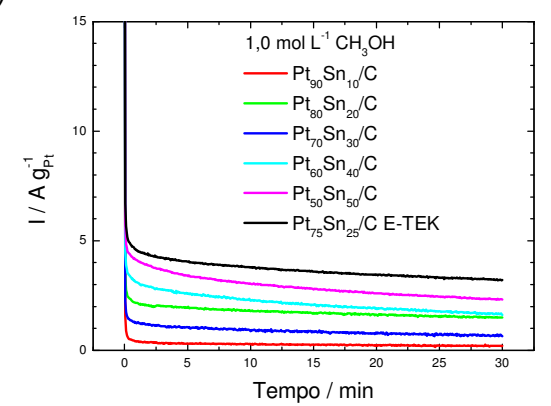

Figura 4.15 - a) Comparação dos valores de corrente para os catalisadores PtSn/C preparados por ácido cítrico nas composições atômicas entre Pt:Sn de 90:10, 80:20, 70:30, 60:40 e 50:50 e catalisador comercial da E-TEK na presença de $1 \mathrm{~mol} \cdot \mathrm{L}^{-1}$ de metanol, considerando-se apenas a varredura anódica, corrigida pelo voltamograma base. b) comparação das curvas cronoamperométricas para os mesmos catalisadores com potencial fixo de $500 \mathrm{mV}$ por $30 \mathrm{~min}$. 
Analisando a Figura 4.15a notou-se que os eletrocatalisadores $\mathrm{Pt}_{60} \mathrm{Sn}_{40} / \mathrm{C}$ e $\mathrm{Pt}_{50} \mathrm{Sn}_{50} / \mathrm{C}$ apresentaram melhores atividades catalíticas na região de interesse tecnológico com relação as demais formulações preparadas, sendo que para os resultados de cronoamperometria (Figura 4.15b) o catalisador $\mathrm{Pt}_{50} \mathrm{Sn}_{50} / \mathrm{C}$ apresentou melhor desempenho com relação ao sistema $\mathrm{Pt}_{60} \mathrm{Sn}_{40} / \mathrm{C}$. Este melhor desempenho em relação as demais composições pode ser atribuído principalmente ao menor tamanho de cristalito das composições $\mathrm{Pt}_{60} \mathrm{Sn}_{40} / \mathrm{C}$ e $\mathrm{Pt}_{50} \mathrm{Sn}_{50} / \mathrm{C}$. Um menor tamanho de cristalito resulta numa maior área superficial o que poderia contribuir para eletro-oxidação do metanol. $\mathrm{O}$ eletrocatalisador $\mathrm{Pt}_{75} \mathrm{Sn}_{25} / \mathrm{C}$ da $\mathrm{E}$-TEK apresentou desempenho ligeiramente inferior ao eletrocatalisador $\mathrm{Pt}_{60} \mathrm{Sn}_{40} / \mathrm{C}$ preparado, pela análise de varredura anódica (Figura 4.15a), mas apresentou um desempenho superior aos eletrocatalisadores preparados para a técnica de cronoamperometria indicando que catalisador $\mathrm{Pt}_{75} \mathrm{Sn}_{25} / \mathrm{C}$ da E-TEK sofre uma menor desativação parcial quando submetidos a maiores tempos de operação na oxidação de metanol.

Para os estudos de oxidação direta de alcoóis em célula a combustível unitária foram selecionados os catalisadores $\mathrm{Pt}_{60} \mathrm{Sn}_{40} / \mathrm{C}$ e $\mathrm{Pt}_{50} \mathrm{Sn}_{50} / \mathrm{C}$ preparados pelo método do ácido cítrico em comparação aos catalisadores comerciais $\mathrm{Pt} / \mathrm{C}$ e $\mathrm{Pt}_{75} \mathrm{Sn}_{25} / \mathrm{C}$ da E-TEK.

Para obtenção de informações com relação à atividade destes eletrocatalisadores em condições reais de operação foram realizados ensaios em célula a combustível unitária $\left(5 \mathrm{~cm}^{2}\right)$ alimentadas diretamente por metanol e etanol. Os experimentos foram realizados com a pressurização da saída de oxigênio do cátodo (backpressure) em três diferentes pressões absolutas: 1, 2 e 3 bar. 
Na Figura 4.16 são mostradas as curvas de polarização obtidas frente a eletro-oxidação do metanol para os catalisadores $\mathrm{Pt}_{60} \mathrm{Sn}_{40} / \mathrm{C}$ e $\mathrm{Pt}_{50} \mathrm{Sn}_{50} / \mathrm{C}$ preparados pelo método do ácido cítrico em comparação aos catalisadores comerciais $\mathrm{Pt} / \mathrm{C}$ e $\mathrm{Pt}_{75} \mathrm{Sn}_{25} / \mathrm{C}$ da E-TEK em diferentes pressões absolutas do cátodo. 

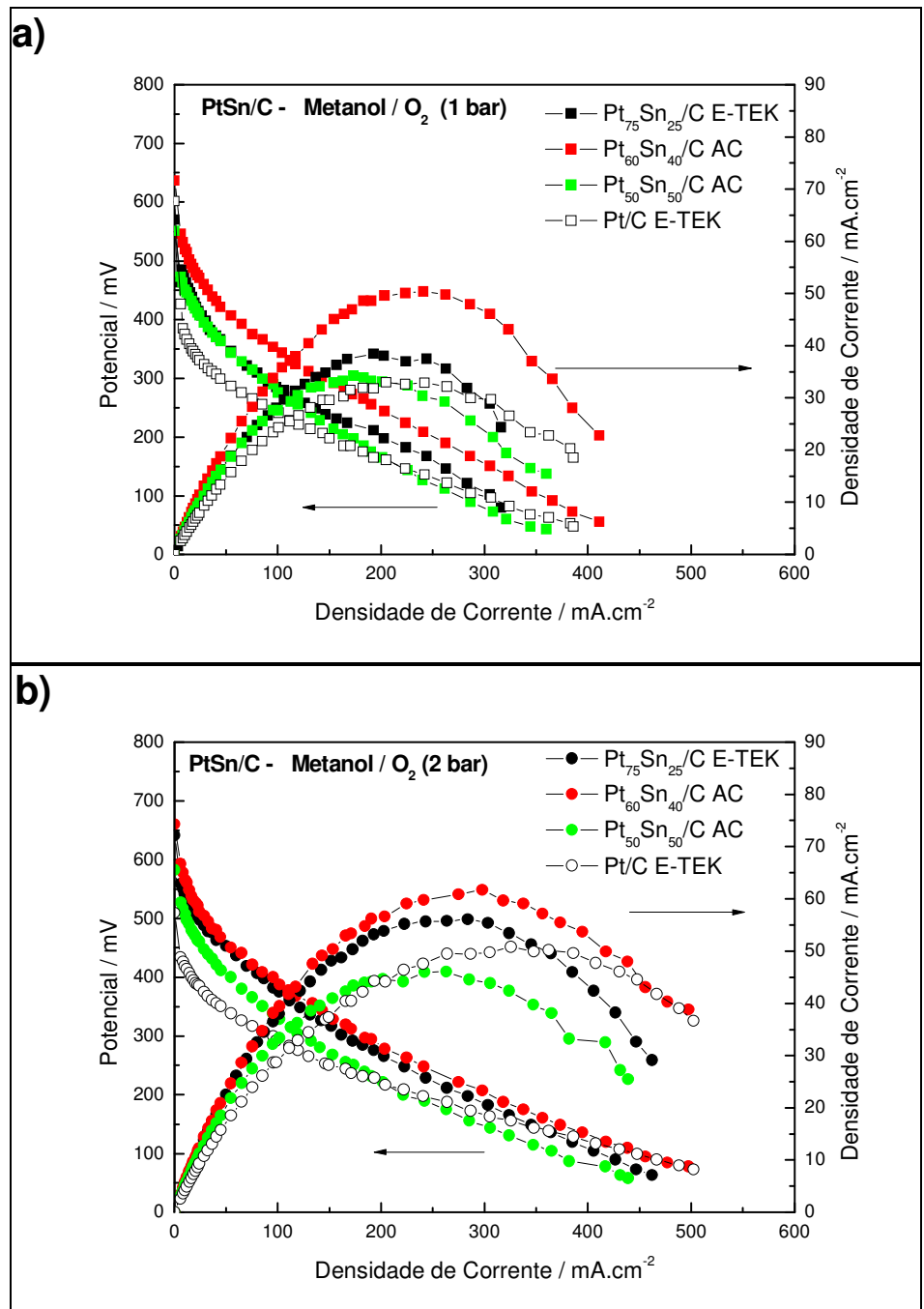

c)

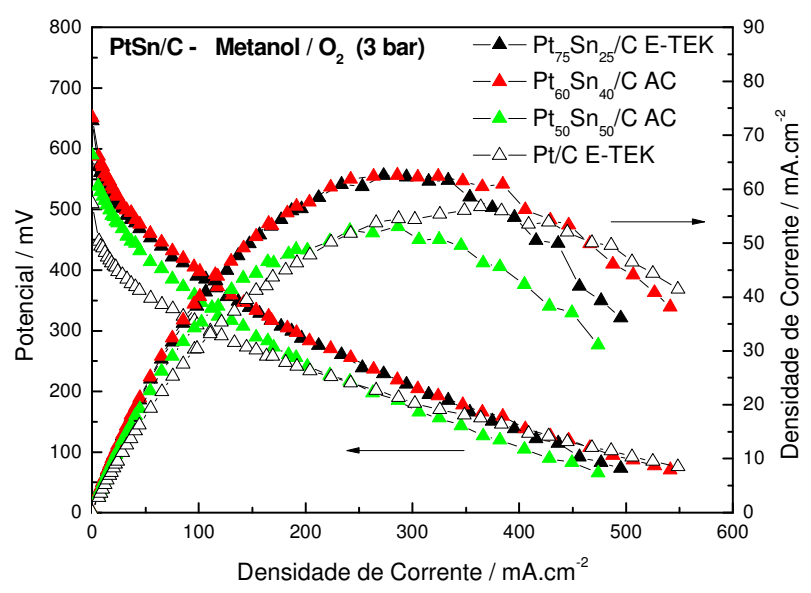

Figura 4.16 - Curvas de polarização para $\mathrm{Pt}_{50} \mathrm{Sn}_{50} / \mathrm{C}, \mathrm{Pt}_{60} \mathrm{Sn}_{40} / \mathrm{C}$ e Pt/C, $\mathrm{Pt}_{75} \mathrm{Sn}_{25} / \mathrm{C}(\mathrm{E}-$ TEK), a $90^{\circ} \mathrm{C}$, fluxo $\cong 1 \mathrm{~mL} \mathrm{~min}^{-1}$ de solução de metanol $\left(2 \mathrm{~mol} \mathrm{~L}^{-1}\right)$, fluxo de $\mathrm{O}_{2}$ de $500 \mathrm{~mL} \mathrm{~min}^{-1}$, em diferentes pressões na saída do $\mathrm{O}_{2}$ de: a) 1 bar; b) 2 bar e c) 3 bar. 
Observou-se que na a eletro-oxidação de etanol em célula a combustível para o sistema PtSn/C ocorreu um aumento do potencial de circuito aberto, bem como um aumento global de corrente para todos os catalisadores a medida que se aumentou a pressão no oxigênio do cátodo. $O$ aumento da pressão de oxigênio pode melhorar o transporte de oxigênio à camada catalítica do cátodo, melhorando a reação de redução de oxigênio diminuindo o crossover de metanol. Os testes em células a combustível alimentadas diretamente por metanol a 1 bar, mostraram que o catalisador $\mathrm{Pt}_{50} \mathrm{Sn}_{50} / \mathrm{C}$ teve um desempenho similar aos catalisadores comerciais $\mathrm{Pt}_{75} \mathrm{Sn}_{25} / \mathrm{C}$ e Pt/C da ETEK. Já o catalisador $\mathrm{Pt}_{60} \mathrm{Sn}_{40} / \mathrm{C}$ preparado teve o melhor desempenho e apresentou maior densidade de potência. Com o aumento da pressão do oxigênio do cátodo houve um aumento de densidade de corrente de todos os catalisadores, entretanto para a eletro-oxidação do metanol todos catalisadores PtSn apresentaram desempenhos similares, inclusive ao catalisador $\mathrm{Pt} / \mathrm{C}$. Este comportamento sugere que existam catalisadores específicos para cada combustível. Estes catalisadores binários PtSn, por exemplo, poderiam ser mais efetivos para eletro-oxidação do etanol do que do metanol, já que obtiveram densidade de potência não muito maior que o catalisador $\mathrm{Pt} / \mathrm{C}$.

A 3 bar os catalisadores $\mathrm{Pt}_{60} \mathrm{Sn}_{40} / \mathrm{C}$ e o $\mathrm{Pt}_{75} \mathrm{Sn}_{25} / \mathrm{C}$ E-TEK resultaram em maiores densidades de potência $\left(63 \mathrm{~mW} \mathrm{~cm}^{-2}\right)$, seguidos dos catalisadores $\mathrm{Pt} / \mathrm{C}\left(57 \mathrm{~mW} \mathrm{~cm}^{-2}\right)$ e $\mathrm{Pt}_{50} \mathrm{Sn}_{50} / \mathrm{C}\left(53 \mathrm{~mW} \mathrm{~cm}^{-2}\right)$.

Foram também realizados experimentos para a eletro-oxidação do etanol para os catalisadores PtSn/C preparados e o eletrocatalisador comercial da E-TEK. 
Na Figura 4.17 são ilustrados os resultados obtidos em meia célula eletroquímica frente a eletro-oxidação do etanol para os catalisadores de PtSn/C preparados em diferentes composições atômicas.

a)

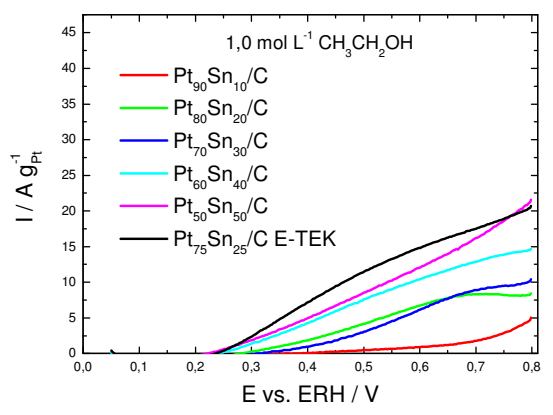

b)

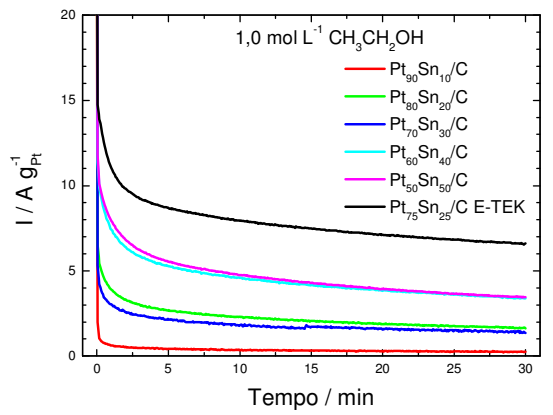

Figura 4.17 - a) Comparação dos valores de corrente para os catalisadores $\mathrm{PtSn} / \mathrm{C}$ preparados por ácido cítrico nas composições atômicas entre Pt:Sn de 90:10, 80:20, 70:30, 60:40 e 50:50 e catalisador comercial da E-TEK na presença de $1 \mathrm{~mol} \cdot \mathrm{L}^{-1} \mathrm{de}$ etanol, considerando-se apenas a varredura anódica, corrigida pelo voltamograma base. b) comparação das curvas cronoamperométricas para os mesmos catalisadores com potencial fixo de $500 \mathrm{mV}$ por $30 \mathrm{~min}$.

As correntes de início de oxidação do etanol para os catalisadores $\mathrm{Pt}_{60} \mathrm{Sn}_{40} / \mathrm{C}, \mathrm{Pt}_{50} \mathrm{Sn}_{50} / \mathrm{C}$ preparados e o $\mathrm{Pt}_{75} \mathrm{Sn}_{25} / \mathrm{C}$ E-TEK ocorrem em menores potenciais ( $\cong 0,25 \vee$ vs $E R H)$ com relação a metanol ( $00,35 \vee$ vs $E R H)$, indicando que estes catalisadores são mais efetivos para oxidação do etanol. 0 catalisador comercial da E-TEK apresenta um melhor desempenho com relação aos catalisadores preparados tanto através das varreduras anódicas como pelas medidas de cronoamperometria para a eletro-oxidação do etanol a temperatura ambiente.

Este resultado pode estar relacionado com o fato de que o estanho não ligado a platina, poder se dissolver em meio ácido, principalmente em potenciais $\geq 0,5 \mathrm{~V}$ vs $\mathrm{ERH}$ se submetido por longos ciclos voltamétricos de estabilização, como observado por Wang e colaboradores [59]. O catalisador 
$\mathrm{Pt}_{75} \mathrm{Sn}_{25} / \mathrm{C}$ E-TEK, por apresentar maior quantidade de estanho na forma de liga do que os produzidos pelo método do ácido cítrico poderia apresentar uma melhor atividade catalítica após os ciclos de estabilização a temperatura ambiente.

Uma explicação mais plausível para estes resultados poderia estar relacionada às diferenças observadas quanto ao tamanho de partícula, ou seja, o catalisador $\mathrm{Pt}_{75} \mathrm{Sn}_{25} / \mathrm{C}$ E-TEK apresentou tamanhos de partículas inferiores, quando comparado aos sistemas $\mathrm{PtSn} / \mathrm{C}$ preparados. Conseqüentemente o sistema da E-TEK poderia apresentar uma maior área ativa, a qual poderia resultar em uma maior atividade catalítica deste catalisador quando submetido aos estudos a temperatura ambiente.

$\mathrm{Na}$ Figura 4.18 são mostrados os testes em células a combustível unitárias alimentadas diretamente por etanol para os catalisadores selecionados $\mathrm{Pt}_{60} \mathrm{Sn}_{40} / \mathrm{C}$ e $\mathrm{Pt}_{50} \mathrm{Sn}_{50} / \mathrm{C}$ e os catalisadores comerciais da E-TEK em três diferentes pressões do cátodo (1, 2 e 3 bar). 
a)

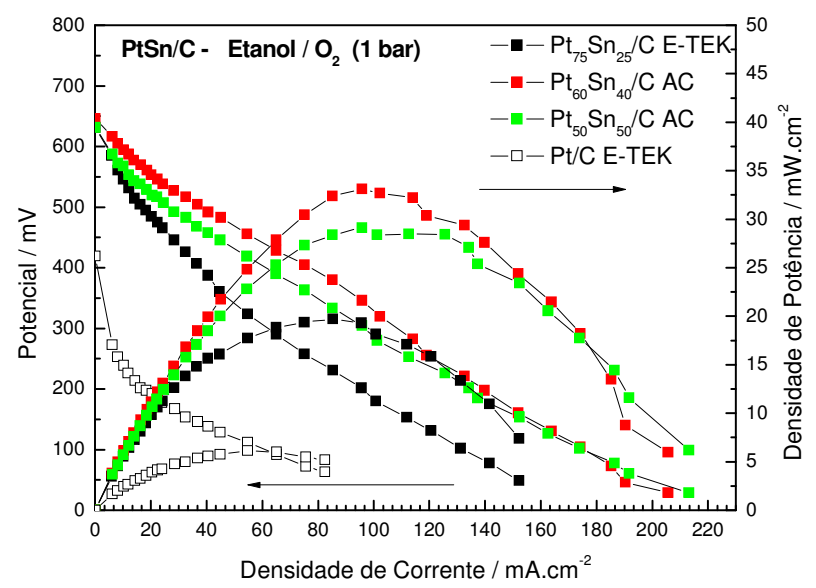

a)

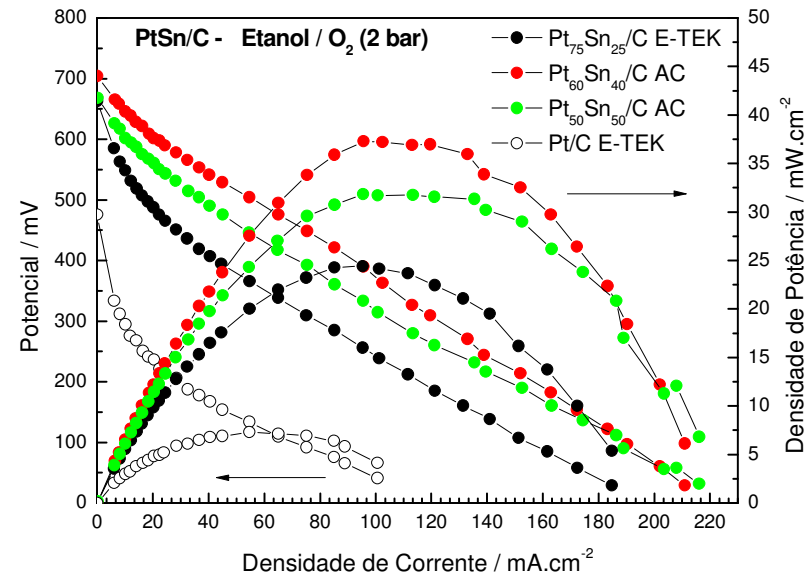

c)

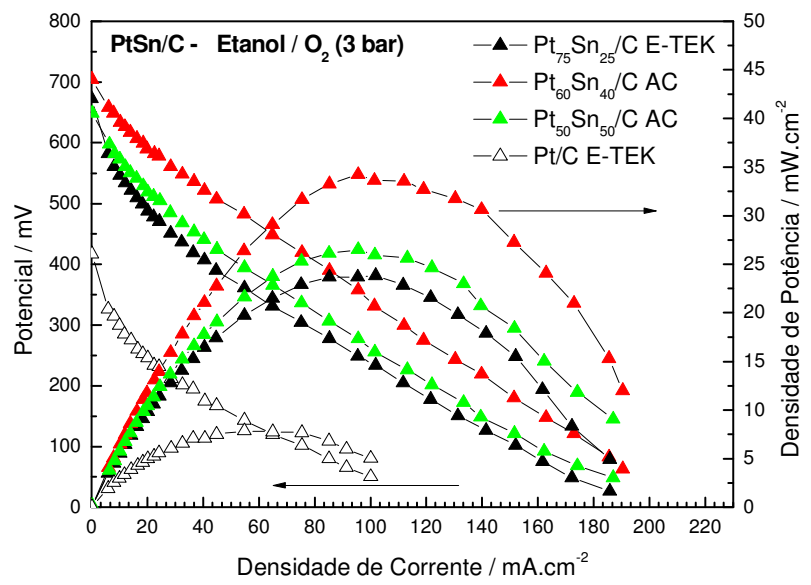

Figura 4.18 - Curvas de polarização para $\mathrm{Pt}_{50} \mathrm{Sn}_{50} / \mathrm{C}, \mathrm{Pt}_{60} \mathrm{Sn}_{40} / \mathrm{C}$ e Pt/C, $\mathrm{Pt}_{75} \mathrm{Sn}_{25} / \mathrm{C}(\mathrm{E}-$ TEK), a $90^{\circ} \mathrm{C}$, fluxo $\cong 1 \mathrm{~mL} \mathrm{~min}^{-1}$ de solução de etanol $\left(2 \mathrm{~mol} \mathrm{~L}^{-1}\right)$, fluxo de $\mathrm{O}_{2}$ de $500 \mathrm{~mL} \mathrm{~min}^{-1}$, em diferentes pressões na saída do $\mathrm{O}_{2}$ de: a) 1 bar; b) 2 bar e c) 3 bar. 
Na eletro-oxidação de etanol para os eletrocatalisadores PtSn em célula a combustível unitária não foram observados aumentos significativos nos potenciais de circuito aberto à medida que se aumentou a pressão do cátodo, sugerindo que o fluxo de oxigênio utilizado de $500 \mathrm{~mL} \mathrm{~min}^{-1}$, mantido invariável para comparação com os experimentos de oxidação do metanol [84, 85], foi suficiente para diminuir o crossover de etanol. Observou-se que o catalisador $\mathrm{Pt} / \mathrm{C}$ foi rapidamente envenenado pelo etanol e, diferentemente da eletrooxidação do metanol, apresentou o menor desempenho, mostrando que os sistemas PtSn apresentados são realmente mais ativos para oxidação do etanol quando comparado com os estudos frente ao metanol.

Os estudos em células a combustível alimentadas diretamente por etanol com pressão de oxigênio de 2 bar, mostraram que os eletrocatalisadores de $\mathrm{Pt}_{60} \mathrm{Sn}_{40} / \mathrm{C}\left(37 \mathrm{~mW} \mathrm{~cm}^{-2}\right)$ e $\mathrm{Pt}_{50} \mathrm{Sn}_{50} / \mathrm{C}\left(32 \mathrm{~mW} \mathrm{~cm} \mathrm{~cm}^{-2}\right.$ ) preparados pelo método da redução por ácido cítrico apresentam desempenhos superiores aos eletrocatalisadores $\mathrm{Pt}_{75} \mathrm{Sn}_{25} / \mathrm{C}\left(24 \mathrm{~mW} \mathrm{~cm}^{-2}\right)$ e $\mathrm{Pt} / \mathrm{C}\left(7 \mathrm{~mW} \mathrm{~cm}^{-2}\right)$ da E-TEK, diferentemente do que foi observado por varredura anódica e cronoamperometria em testes eletroquímicos a temperatura ambiente. Estes resultados poderiam sugerir que em temperaturas mais elevadas de operação, maiores teores de estanho no eletrocatalisador poderiam favorecer a eletrooxidação do etanol. Estas informações estão de acordo com alguns trabalhos da literatura, onde se tem discutido que a presença de óxidos favorece a eletrooxidação do etanol em menores potenciais e em temperaturas mais elevadas de operação, ou seja, em estudos acima da temperatura ambiente de operação [88, 89, 93]. 


\subsection{Eletro-oxidação de metanol (Comparação PtRu/C e PtSn/C)}

Neste capítulo são apresentados os resultados comparativos da eletrooxidação do metanol para os eletrocatalisadores PtRu/C e PtSn/C preparados via ácido cítrico que apresentaram melhores resultados paras reações estudadas.

Na Figura 4.19 são apresentados os resultados comparativos para a eletro-oxidação do metanol em meia célula eletroquímica, a temperatura ambiente, para os catalisadores $\mathrm{Pt}_{80} \mathrm{Ru}_{20} / \mathrm{C}, \mathrm{Pt}_{50} \mathrm{Ru}_{50} / \mathrm{C}, \mathrm{Pt}_{50} \mathrm{Ru}_{50} / \mathrm{C}$ E-TEK, $\mathrm{Pt}_{60} \mathrm{Sn}_{40} / \mathrm{C}, \mathrm{Pt}_{50} \mathrm{Sn}_{50} / \mathrm{C}$ e $\mathrm{Pt}_{75} \mathrm{Sn}_{25} / \mathrm{C}$ E-TEK.

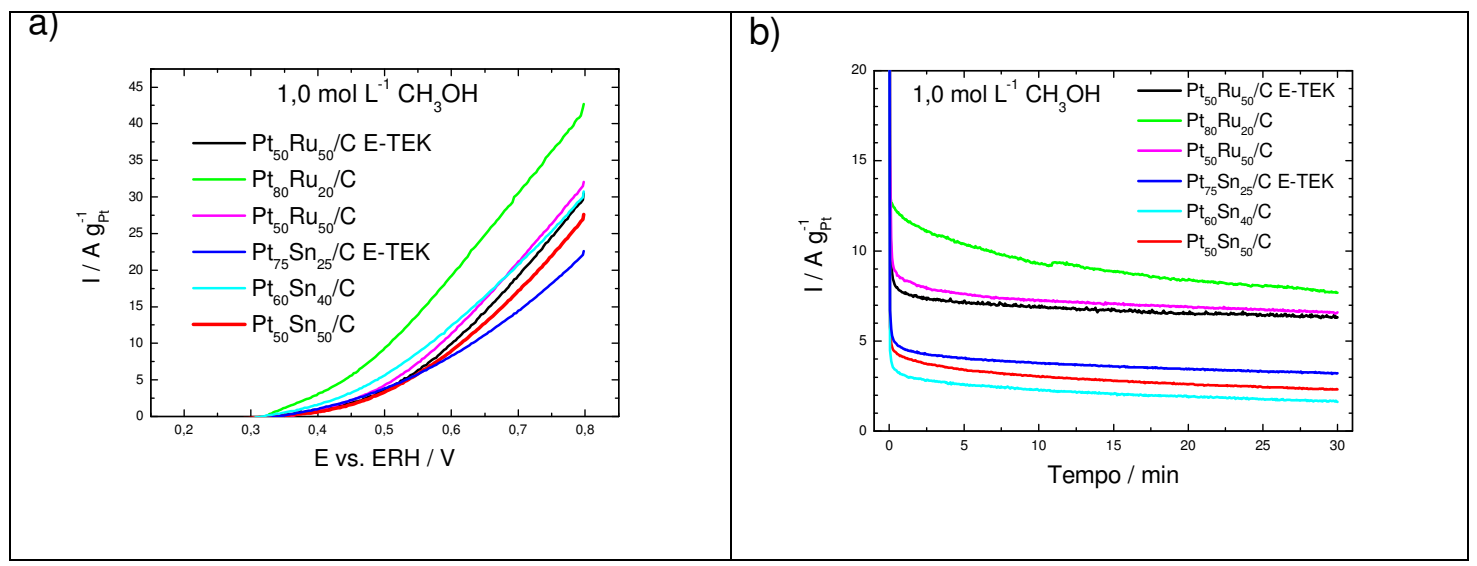

Figura 4.19 - a) Comparação dos valores de corrente para os catalisadores PtRu/C e $\mathrm{PtSn} / \mathrm{C}$ preparados por ácido cítrico e catalisadores comerciais da E-TEK na presença de $1 \mathrm{~mol} \cdot \mathrm{L}^{-1}$ de metanol, considerando-se apenas a varredura anódica, corrigida pelo voltamograma base. b) comparação das curvas cronoamperométricas para os mesmos catalisadores com potencial fixo de $500 \mathrm{mV}$ por $30 \mathrm{~min}$.

Os estudos para a eletro-oxidação do metanol mostraram que o eletrocatalisador $\mathrm{Pt}_{80} \mathrm{Ru}_{20} / \mathrm{C}$ preparado via redução por ácido cítrico resultou em um desempenho superior com relação aos demais eletrocatalisadores $\mathrm{PtRu} / \mathrm{C}$ e eletrocatalisadores $\mathrm{PtSn} / \mathrm{C}$ tanto por varredura anódica quanto por cronoamperometria. Os eletrocatalisadores $\mathrm{Pt}_{80} \mathrm{Ru}_{20} / \mathrm{C}, \mathrm{Pt}_{50} \mathrm{Ru}_{50} / \mathrm{C}$ preparados apresentaram melhores desempenho com relação aos catalisadores 
comerciais, indicando que a metodologia é bastante efetiva para a produção de eletrocatalisadores para estudos frente a eletro-oxidação do metanol a temperatura ambiente. Os resultados para $\mathrm{PtSn} / \mathrm{C}$ frente a eletro-oxidação do metanol mostram que estes apresentam uma atividade bastante inferior aos eletrocatalisadores $\mathrm{PtRu} / \mathrm{C}$ quando considerados os resultados de cronoamperometria. Estes resultados indicaram que os eletrocatalisadores $\mathrm{PtSn} / \mathrm{C}$ são menos efetivos para os estudos a temperatura ambiente e que mudanças nas sínteses destes eletrocatalisadores poderiam ser realizadas a fim de que se possa tentar obter melhores desempenhos.

$\mathrm{Na}$ Figura 4.20 são ilustrados os resultados para eletro-oxidação do metanol em condições reais de operação, ou seja, os testes em células a combustível alimentadas diretamente por metanol para os eletrocatalisadores $\mathrm{PtRu} / \mathrm{C}$ e PtSn/C preparados por ácido cítrico e catalisadores comerciais da ETEK.

Na Figura 4.21 é apresentada uma comparação de densidade de potência obtida para todos os MEAs testados na eletro-oxidação de metanol a 2 bar. 


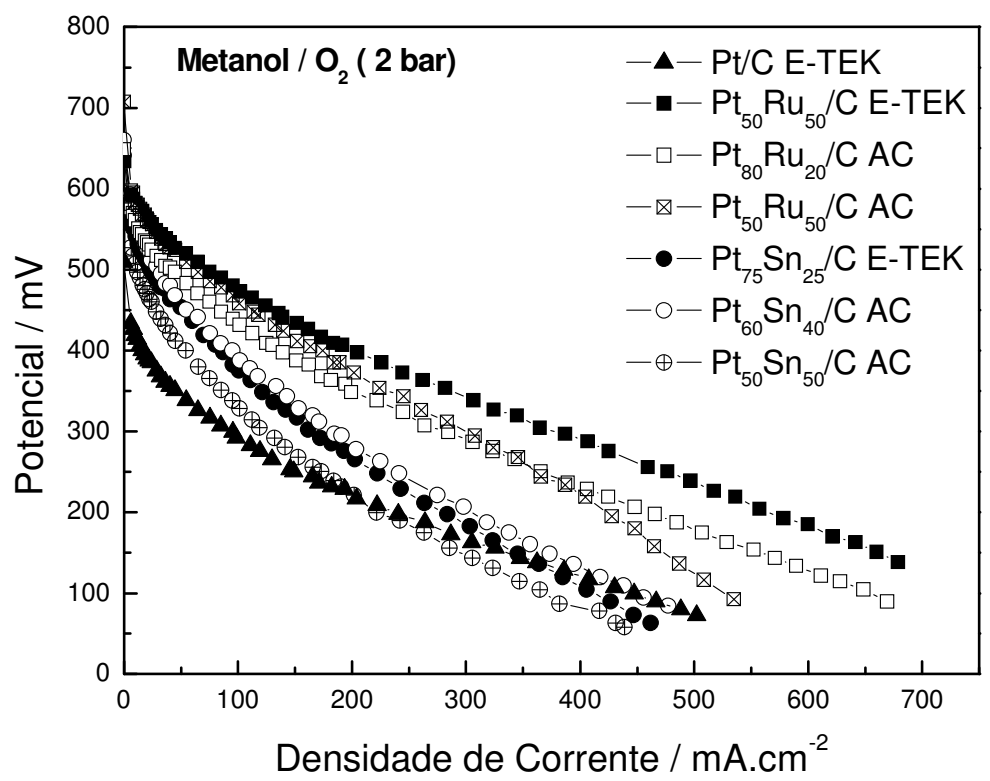

Figura 4.20 - Comparação das curvas de polarização de todos os MEAs testados em DMFC $5 \mathrm{~cm}^{2}$, Metanol $2 \mathrm{~mol} \mathrm{~L}^{-1} \mathrm{com}$ fluxo $\cong 1 \mathrm{~mL} \mathrm{~min}^{-1}$, Temperatura da Cel $=90^{\circ} \mathrm{C}$,

Temperatura $\mathrm{O}_{2}=90^{\circ} \mathrm{C}$, Fluxo $\mathrm{O}_{2}=500 \mathrm{~mL} \mathrm{~min}^{-1}$, Pressão de saída $\mathrm{O}_{2}=2$ bar.

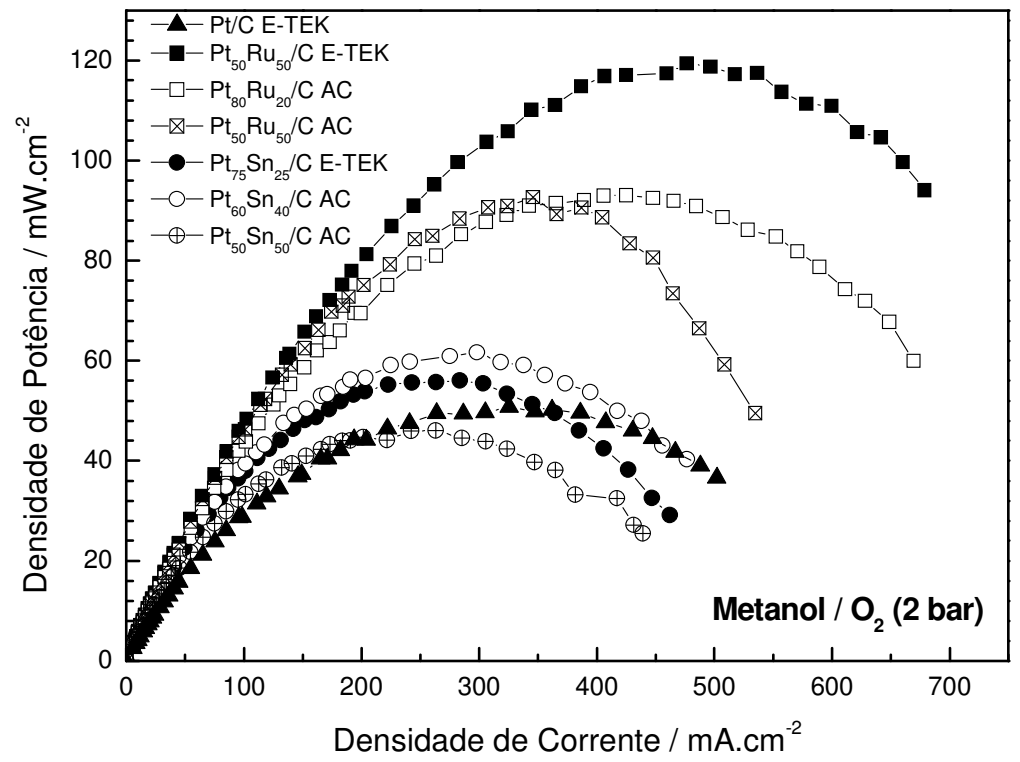

Figura 4.21 - Comparação de densidades de potência de todos os MEAs testados em DMFC $5 \mathrm{~cm}^{2}$, Metanol $2 \mathrm{~mol} \mathrm{~L}^{-1} \mathrm{com}$ fluxo $\cong 1 \mathrm{~mL} \mathrm{~min}^{-1}$, Temperatura da Cel $=90^{\circ} \mathrm{C}$, Temperatura $\mathrm{O}_{2}=90^{\circ} \mathrm{C}$, Fluxo $\mathrm{O}_{2}=500 \mathrm{~mL} \mathrm{~min}^{-1}$, Pressão de saída $\mathrm{O}_{2}=2$ bar. 
Os estudos em células a combustível alimentadas diretamente por metanol também mostraram que os eletrocatalisadores $\mathrm{PtRu} / \mathrm{C}$ são mais efetivos para a eletro-oxidação do metanol do que eletrocatalisadores $\mathrm{PtSn} / \mathrm{C}$, estando de acordo com os resultados de voltametria cíclica (varreduras anódicas de potencial) e cronoamperometria. Os eletrocatalisadores $\mathrm{Pt}_{50} \mathrm{Ru}_{50} / \mathrm{C}$ apresentaram melhores desempenhos que $\mathrm{Pt}_{80} \mathrm{Ru}_{20} / \mathrm{C}$ nos testes em células a combustível, ou seja, nos testes em valores de temperaturas mais altas, estando estes dados contraditórios aos resultados de voltametria cíclica.

Outro fato a se considerar, seria a possibilidade de que em maiores temperaturas o rutênio passaria a ter um papel fundamental na eletro-oxidação do metanol, podendo o álcool adsorver-se também sobre os sítios de rutênio o que levaria a um melhor desempenho para as composições de $\mathrm{PtRu} / \mathrm{C}$ em que houvesse maior paridade de sítios ativos entre $\mathrm{Pt}$ e $\mathrm{Ru}$. Esta paridade seria alcançada para maiores teores de rutênio no catalisador, ou seja, para composições $\mathrm{Pt}_{50} \mathrm{Ru}_{50} / \mathrm{C}$.

$\mathrm{O}$ catalisador $\mathrm{Pt}_{80} \mathrm{Ru}_{20} / \mathrm{C}$ preparado resulta numa densidade de potência cerca de $20 \mathrm{~mW} \mathrm{~cm}{ }^{-2}$ a menos que o catalisador $\mathrm{Pt}_{50} \mathrm{Ru}_{50} / \mathrm{C}$ E-TEK na eletrooxidação do metanol nas condições estudadas. Entretanto, estudos de Song e colaboradores demonstram a possibilidade de se encontrar condições otimizadas de operação de uma DMFC (temperatura, fluxo e pressões ideais) para catalisadores com diferentes composições atômicas, sendo que estas condições definidas para cada catalisador preparado poderia favorecer a obtenção de maiores densidades de potência [90]. 


\subsection{Eletro-oxidação de etanol (Comparação PtRu/C e PtSn/C)}

Na Figura 4.22 apresentados os resultados comparativos para a eletrooxidação do etanol em meia célula eletroquímica, a temperatura ambiente, para os catalisadores $\mathrm{Pt}_{80} \mathrm{Ru}_{20} / \mathrm{C}, \mathrm{Pt}_{50} \mathrm{Ru}_{50} / \mathrm{C}, \mathrm{Pt}_{50} \mathrm{Ru}_{50} / \mathrm{C}$ E-TEK, $\mathrm{Pt}_{60} \mathrm{Sn}_{40} / \mathrm{C}$, $\mathrm{Pt}_{50} \mathrm{Sn}_{50} / \mathrm{C}$ e $\mathrm{Pt}_{75} \mathrm{Sn}_{25} / \mathrm{C}$ E-TEK.

a)

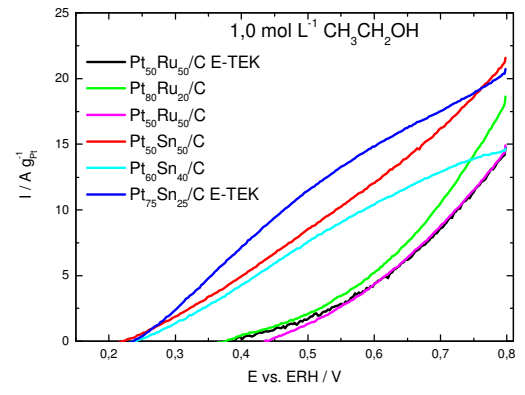

b)

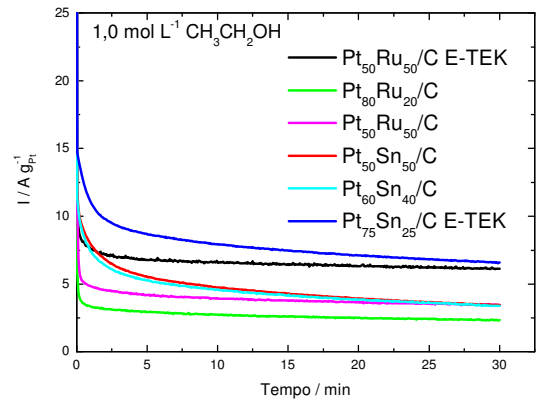

Figura 4.22 - a) Comparação dos valores de corrente para os catalisadores $\mathrm{PtRu} / \mathrm{C}$ e $\mathrm{PtSn} / \mathrm{C}$ preparados por ácido cítrico e catalisadores comercial da E-TEK na presença de $1 \mathrm{~mol} \cdot \mathrm{L}^{-1}$ de etanol, considerando-se apenas a varredura anódica, corrigida pelo voltamograma base. b) comparação das curvas cronoamperométricas para os mesmos catalisadores com potencial fixo de $500 \mathrm{mV}$ por $30 \mathrm{~min}$.

Os resultados de varredura anódica para a eletro-oxidação do etanol mostraram que tanto os eletrocatalisadores $\mathrm{PtSn} / \mathrm{C}$ preparados quanto o comercial são mais efetivos do que os eletrocatalisadores de PtRu/C. O início da oxidação do etanol também ocorre em menores potencias para os sistemas $\mathrm{PtSn} / \mathrm{C}$ com relação aos sistemas $\mathrm{PtRu} / \mathrm{C}$, indicando que os sistemas $\mathrm{PtSn}$ são mais promissores para serem empregados nos estudos em células a combustível alimentadas diretamente por etanol.

$\mathrm{Na}$ análise de cronoamperometria ambos eletrocatalisadores comerciais da E-TEK (PtRu e PtSn) se mostraram mais efetivos do que os eletrocatalisadores de PtRu e PtSn preparados pelo método da redução via 
ácido cítrico. Estes resultados sugerem que, quando submetidos a maiores tempo de operação, os eletrocatalisadores comerciais sofrem uma menor desativação para a eletro-oxidação do etanol com relação aos eletrocatalisadores preparados via redução por ácido cítrico, sendo que este fato foi mais evidente a temperatura ambiente. Outro fator a ser considerado é a baixa cristalinidade dos catalisadores PtRu e a presença nos catalisadores de PtSn de cristalitos com tamanhos considerados não efetivos para os estudos frente a eletro-oxidação de etanol, os quais levariam a uma menor área ativa. Zhou e colaboradores [91] relatam que se deve buscar uma superfície catalítica com uma quantidade ótima entre platina e óxidos já que, segundo os autores, quantidades apreciáveis de óxidos poderiam bloquear parcialmente os sítios ativos de Pt inibindo a adsorção de etanol em altas densidades de correntes.

Na Figura 4.23 são apresentados os resultados para eletro-oxidação do etanol em células a combustível alimentadas diretamente por etanol para os eletrocatalisadores $\mathrm{PtRu} / \mathrm{C}$ e $\mathrm{PtSn} / \mathrm{C}$, preparados pelo método do ácido cítrico em comparação com os catalisadores comerciais da E-TEK. 


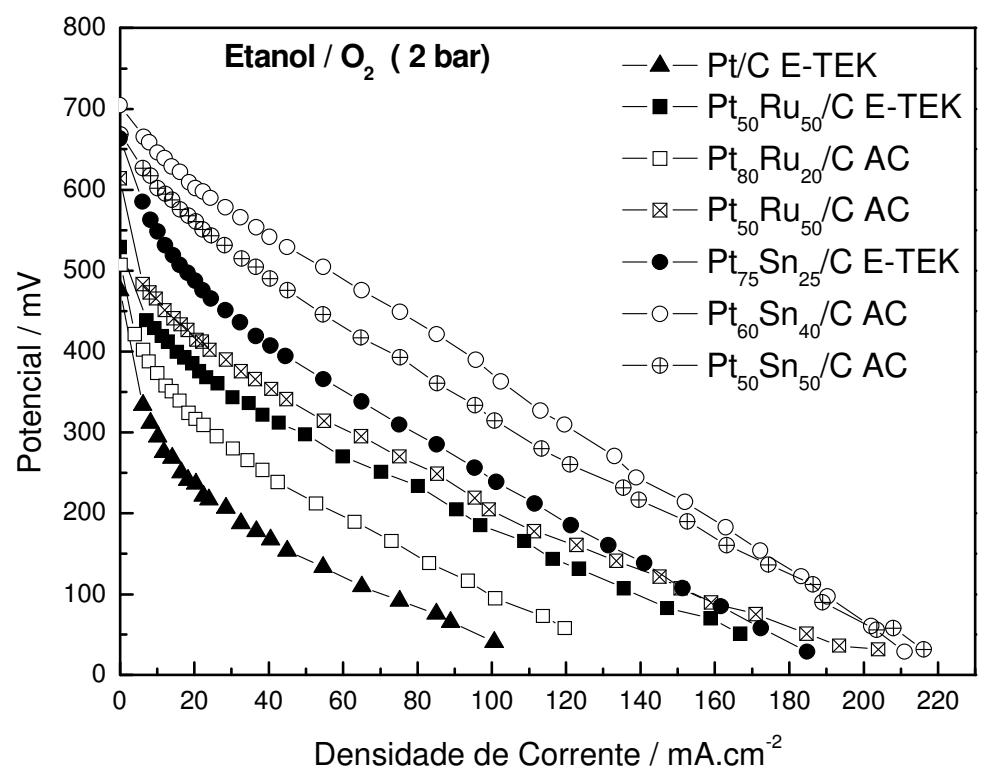

Figura 4.23 - Comparação das curvas de polarização de todos os MEAs testados em DEFC $5 \mathrm{~cm}^{2}$, Etanol $2 \mathrm{~mol} \mathrm{~L}^{-1} \mathrm{com}$ fluxo $\cong 1 \mathrm{~mL} \mathrm{~min}^{-1}$, Temperatura da Cel $=90^{\circ} \mathrm{C}$, Temperatura $\mathrm{O}_{2}=90^{\circ} \mathrm{C}$, Fluxo $\mathrm{O}_{2}=500 \mathrm{~mL} \mathrm{~min}^{-1}$, Pressão de saída $\mathrm{O}_{2}=2$ bar.

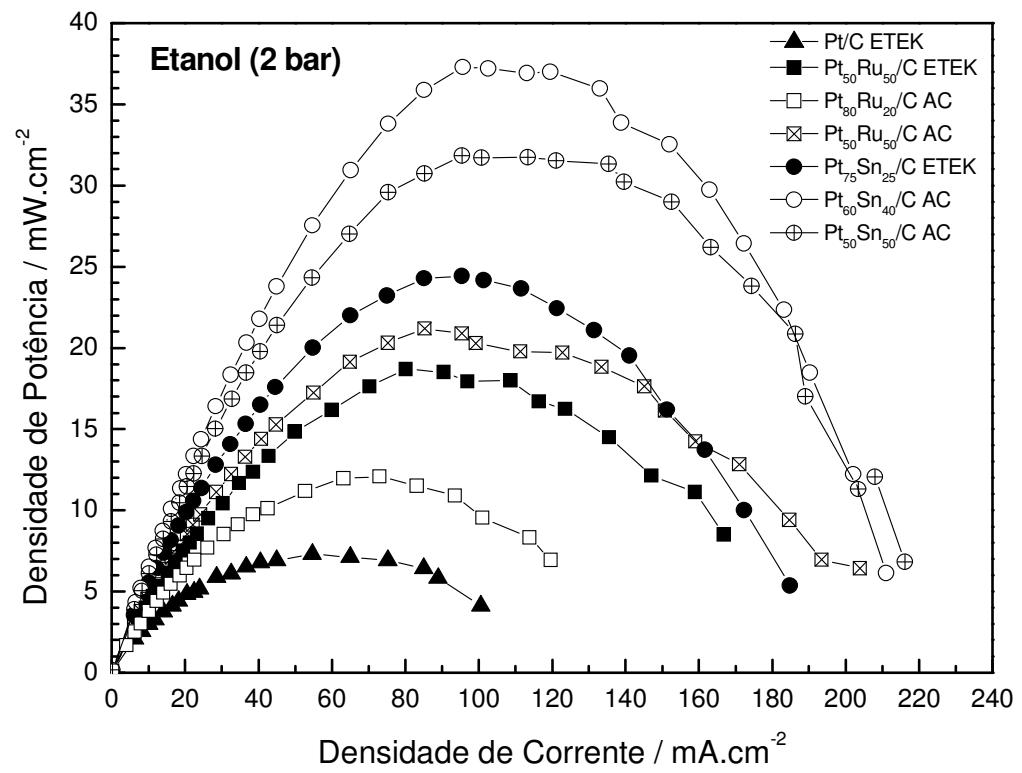

Figura 4.24 - Comparação das densidades de potência de todos os MEAs testados em DEFC $5 \mathrm{~cm}^{2}$, Etanol $2 \mathrm{~mol} \mathrm{~L}^{-1} \mathrm{com}$ fluxo $\cong 1 \mathrm{~mL} \mathrm{~min}^{-1}$, Temperatura da Cel $=90^{\circ} \mathrm{C}$, Temperatura $\mathrm{O}_{2}=90^{\circ} \mathrm{C}$, Fluxo $\mathrm{O}_{2}=500 \mathrm{~mL} \mathrm{~min}^{-1}$, Pressão de saída $\mathrm{O}_{2}=2$ bar. 
Os estudos em células a combustível alimentadas diretamente por etanol também mostraram que os eletrocatalisadores PtSn/C são mais efetivos para a eletro-oxidação do etanol do que eletrocatalisadores $\mathrm{PtRu} / \mathrm{C}$, estando de acordo com os resultados de varredura anódica e cronoamperometria e com resultados recentes da literatura [36,92].

Os eletrocatalisadores $\mathrm{Pt}_{60} \mathrm{Sn}_{40} / \mathrm{C}$ apresentaram melhores desempenhos a $90{ }^{\circ} \mathrm{C}$ que os eletrocatalisadores $\mathrm{PtRu}$ preparados e os catalisadores comercias da E-TEK. Uma justificativa para o $\mathrm{Pt}_{60} \mathrm{Sn}_{40} / \mathrm{C}$ ser mais efetivo poderia ser pela maior presença de espécies oxigenadas nestes catalisadores e estas espécies poderiam favorecer a eletro-oxidação do etanol em maiores temperatura de operação com relação ao catalisador $\mathrm{Pt}_{75} \mathrm{Sn}_{25} / \mathrm{C}$ E-TEK que é considerado pelo fabricante $100 \%$ liga. Jiang e colaboradores [93] investigaram o desempenho de eletrocatalisadores $\mathrm{PtSn} / \mathrm{C}$ na forma de liga e na forma de óxidos de estanho $\left(\mathrm{PtSnO}_{\mathrm{x}}\right)$ e observaram que o catalisador composto por óxidos apresentou atividade catalítica mais elevada na oxidação de etanol do que a liga de PtSn.

Entretanto, grandes quantidades de óxidos de estanho podem levar ao aumento da resistência ôhmica da célula unitária [94], tornando a curva mais inclinada. Curvas de polarização com inclinação semelhante a do catalisador apresentado neste trabalho, $\mathrm{Pt}_{60} \mathrm{Sn}_{40} / \mathrm{C}$ preparado pelo método do ácido cítrico, são encontradas na literatura $[41,95]$ onde os autores também utilizaram redutores químicos para obtenção dos seus catalisadores $\mathrm{PtSnO}_{\mathrm{x}} / \mathrm{C}$.

O melhor desempenho do eletrocatalisador $\mathrm{Pt}_{60} \mathrm{Sn}_{40} / \mathrm{C}$ com relação ao catalisador $\mathrm{Pt}_{50} \mathrm{Ru}_{50} / \mathrm{C}$ da E-TEK a $90{ }^{\circ} \mathrm{C}$, poderia estar relacionado ao fato de os catalisadores PtSn/C serem mais efetivos para a eletro-oxidação do etanol 
com relação aos catalisadores $\operatorname{PtRu/C}[36,92]$ e o efeito do estanho, no catalisador bimetálico, poder ser mais acentuado conforme aumentamos a temperatura de operação. Zhou e colaboradores [96] publicaram um estudo sobre o efeito do teor de estanho do catalisador $\mathrm{PtSn} / \mathrm{C}$ no desempenho da DEFC. Eles variaram a quantidade de estanho de $20 \%$ a $50 \%$ e também observaram um melhor desempenho na eletro-oxidação direta de etanol para eletrocatalisadores com teor de $34 \%$ a $40 \%$ de estanho, operando a célula unitária a $60{ }^{\circ} \mathrm{C}, 75^{\circ} \mathrm{C}$ e a $90{ }^{\circ} \mathrm{C}$. Estes resultados encontram-se de acordo com os observados neste trabalho, onde o catalisador $\mathrm{Pt}_{60} \mathrm{Sn}_{40} / \mathrm{C}$ apresentou 0 melhor desempenho frente a eletro-oxidação direta de etanol a $90{ }^{\circ} \mathrm{C}$ dentre todos os demais.

Na Tabela 5 é apresentada uma comparação entre os dados de tamanho médio de cristalitos estimados por DRX e tamanho médio de partícula calculados por MET, além de um resumo dos valores máximos de densidades de potencia obtidas na eletro-oxidação de metanol e etanol em célula unitária em diferentes pressões do oxigênio, para cada catalisador testado.

Tabela 5 - Tamanhos de cristalito $(d)$ e de partícula $(t)$ e comparação da máxima densidade de potência obtida em cada condição de pressurização do cátodo da DAFC. Em destaque, as melhores condições obtidas para oxidação de cada álcool.

\begin{tabular}{|c|c|c|c|c|c|c|c|c|}
\hline \multirow{3}{*}{ Catalisador } & \multirow{3}{*}{$\begin{array}{c}\text { DRX } \\
d \\
(\mathrm{~nm}) \\
\end{array}$} & \multirow{3}{*}{$\begin{array}{c}\text { MET } \\
t \\
(\mathrm{~nm}) \\
\end{array}$} & \multicolumn{6}{|c|}{ Máx. Densidade de Potência DAFC $90^{\circ} \mathrm{C}\left(\mathrm{mW} \mathrm{cm}^{-2}\right)$} \\
\hline & & & \multicolumn{3}{|c|}{ METANOL } & \multicolumn{3}{|c|}{ ETANOL } \\
\hline & & & 1 bar & 2 bar & 3 bar & 1 bar & 2 bar & 3 bar \\
\hline $\mathrm{Pt}_{50} \mathrm{Ru}_{50} / \mathrm{C} \mathrm{AC}$ & - & 2,6 & 67 & 93 & 96 & 21 & 21 & 20 \\
\hline $\mathrm{Pt}_{80} \mathrm{Ru}_{20} / \mathrm{C} \mathrm{AC}$ & - & 2,2 & 52 & 93 & 103 & 8 & 12 & 13 \\
\hline $\mathrm{Pt}_{50} \mathrm{Ru}_{50} / \mathrm{C}$ ETEK & 3,8 & 3,2 & 80 & 119 & $\underline{123}$ & 19 & 19 & 17 \\
\hline $\mathrm{Pt}_{50} \mathrm{Sn}_{50} / \mathrm{C} \mathrm{AC}$ & 8,5 & 4,8 & 34 & 46 & 53 & 29 & 32 & 27 \\
\hline $\mathrm{Pt}_{60} \mathrm{Sn}_{40} / \mathrm{CAC}$ & 8,7 & 5,2 & 50 & 62 & 63 & 33 & $\underline{37}$ & 34 \\
\hline $\mathrm{Pt}_{75} \mathrm{Sn}_{25} / \mathrm{C}$ ETEK & 3,8 & 3,3 & 38 & 56 & 63 & 20 & 24 & 24 \\
\hline Pt/C (E-TEK) & 3,7 & - & 33 & 51 & 57 & 6 & 7 & 8 \\
\hline
\end{tabular}


Pode-se observar que os catalisadores E-TEK apresentam valores de tamanho médio de cristalito e tamanho médio de partículas com boa aproximação. Já os catalisadores PtSn preparados apresentaram uma variação maior entre o menor e maior valor de partícula por MET o que resultou num valor médio ligeiramente diferente do observado por difração de raios $\mathrm{X}$.

Para a eletro-oxidação do metanol a melhor condição encontrada foi com a pressão de 3 bar na saída do oxigênio do cátodo. Nestas condições apresentaram maior densidade de potência o catalisador $\mathrm{Pt}_{50} \mathrm{Ru}_{50} / \mathrm{C}$ E-TEK (123 $\mathrm{mW} \mathrm{cm}^{-2}$ ) e o $\mathrm{Pt}_{80} \mathrm{Ru}_{20} / \mathrm{C}$ preparado pelo método do ácido cítrico $\left(103 \mathrm{~mW} \mathrm{~cm}^{-2}\right)$.

Para a eletro-oxidação do etanol a melhor condição de pressão de saída do oxigênio, dentre as estudadas, foi a de 2 bar. $\mathrm{O}$ catalisador $\mathrm{Pt}_{60} \mathrm{Sn}_{40} / \mathrm{C}$ e $\mathrm{Pt}_{50} \mathrm{Sn}_{50} / \mathrm{C}$ preparados pelo método do ácido cítrico apresentaram os maiores valores de densidade de potência, $37 \mathrm{~mW} \mathrm{~cm}$ e $32 \mathrm{~mW} \mathrm{~cm}^{-2}$, respectivamente. 


\section{CONCLUSÕES}

A adição de $\mathrm{KOH}$ como agente estabilizante na síntese de eletrocatalisadores $\mathrm{PtRu} / \mathrm{C}$ e $\mathrm{PtSn} / \mathrm{C}$ permitiu que houvesse uma melhor dispersão das nanopartículas no suporte, visto que houve uma diminuição no tamanho médio do cristalito em relação aos eletrocatalisadores sintetizados somente na presença do ácido cítrico. Entretanto foram encontradas diferentes condições de pH ideais para síntese de cada um dos sistemas (PtRu e PtSn). Para as sínteses de catalisadores $\mathrm{PtRu} / \mathrm{C}$ foi observado que valores de pH entre 11 e 12 (razão molar entre metais: $\mathrm{KOH}=1: 10$ ) conduziu a uma maior redução dos metais e um melhor desempenho eletroquímico. Já para a redução química de eletrocatalisadores $\mathrm{PtSn} / \mathrm{C}$ valores de $\mathrm{pH}$ em torno de 5 (razão molar entre metais: $\mathrm{KOH}=1: 5$ ) são indicados.

Os resultados de difração de raios $X$ para os eletrocatalisadores $P t R u / C$ mostram a estrutura cúbica de face centradas típica de platina e suas ligas, enquanto que os eletrocatalisadores de $\mathrm{PtSn} / \mathrm{C}$ preparados apresentam a estrutura cúbica de face centrada da platina e suas ligas, além de fases de óxido de estanho. O tamanho médio de cristalito para os catalisadores $\mathrm{PtRu} / \mathrm{C}$ preparados em condições otimizadas não foi possível de serem determinados a partir do plano cristalino (220) indicando tamanhos médio de cristalitos inferiores a $3 \mathrm{~nm}$, os quais são valores considerados otimizados para os estudos em células a combustível alimentadas diretamente por metanol e etanol, ou a presença de fases amorfas. Já para os catalisadores PtSn/C foram encontrados valores entre 8 e $16 \mathrm{~nm}$, os quais ainda não são valores otimizados para os estudos frente a eletro-oxidação do metanol e etanol. 
As imagens obtidas por MET mostraram uma boa homogeneidade das nanopartículas para os catalisadores $\mathrm{PtRu} / \mathrm{C}$ preparados e para os catalisadores PtRu e PtSn comerciais da E-TEK, enquanto que as imagens para os catalisadores $\mathrm{PtSn} / \mathrm{C}$ preparados apresentaram uma ampla faixa de distribuição de tamanhos de partículas.

Os parâmetros de rede calculados para os eletrocatalisadores $\mathrm{PtRu} / \mathrm{C}$ preparados via redução por ácido cítrico indicaram uma contração de rede cristalina e a formação de liga com a platina em uma certa extensão diferentemente dos catalisadores $\mathrm{PtSn} / \mathrm{C}$ preparados que possuem boa parte do estanho na forma de óxidos no catalisador.

O método de preparação de eletrocatalisadores via redução por ácido cítrico otimizado com a concentração de $\mathrm{KOH}$ adequada permitiu obter catalisadores de PtRu/C e PtSn/C efetivos para os estudos frente a eletrooxidação do metanol e etanol.

Os estudos frente a eletro-oxidação do metanol por voltametria cíclica (varredura anódica) e cronoamperometria para os eletrocatalisadores $\mathrm{PtRu} / \mathrm{C}$ mostraram que o eletrocatalisador $\mathrm{Pt}_{80} \mathrm{Ru}_{20} / \mathrm{C}$ foi mais ativo que os demais catalisadores de PtRu/C e que o catalisador comercial da E-TEK, mostrando que para a temperatura ambiente são necessários um maior número possível de sítios catalíticos de platina disponíveis para adsorção de moléculas de álcool. Contudo os testes de eletro-oxidação do metanol em célula a combustível unitária mostraram que os eletrocatalisadores $\mathrm{Pt}_{50} \mathrm{Ru}_{50} / \mathrm{C}$ são mais efetivos indicando que para maiores valores de temperatura o segundo metal pode ter um papel importante na eletro-oxidação do metanol, ou seja, sobre o segundo metal o metanol também pode estar se adsorvendo, o que levaria um 
melhor desempenho para catalisadores com paridades de sítios catalíticos entre os metais. Acredita-se que a realização de tratamento térmico em temperaturas próximas de $200{ }^{\circ} \mathrm{C}$ nos eletrocatalisadores $\mathrm{PtRu} / \mathrm{C}$ preparados sejam suficientes para aumentar sua cristalinidade e muito provavelmente seu desempenho frente a eletro-oxidação de metanol a temperaturas acima de $90{ }^{\circ} \mathrm{C}$. Entretanto no estágio atual, o catalisador $\mathrm{Pt}_{80} \mathrm{Ru}_{20} / \mathrm{C}$ preparado pelo método do ácido cítrico é promissor para aplicações em células a metanol direto que operem a temperatura ambiente.

Para estudos eletroquímicos na eletro-oxidação do metanol a temperatura ambiente para os sistemas $\mathrm{PtSn} / \mathrm{C}$ os eletrocatalisadores $\mathrm{Pt}_{60} \mathrm{Sn}_{40} / \mathrm{C}$ e $\mathrm{Pt}_{50} \mathrm{Sn}_{50} / \mathrm{C}$ apresentaram melhor desempenho com relação aos demais eletrocatalisadores preparados para a eletro-oxidação do metanol, e um desempenho similar ao eletrocatalisador $\mathrm{Pt}_{75} \mathrm{Sn}_{25} / \mathrm{C}$ E-TEK por voltametria cíclica, enquanto que por cronoamperometria o catalisador E-TEK apresentou melhor desempenho. Entretanto os estudos de eletro-oxidação de metanol em célula a combustível unitária em maiores temperaturas de operação $\left(90^{\circ} \mathrm{C}\right) \circ$ catalisador $\mathrm{Pt}_{60} \mathrm{Sn}_{40} / \mathrm{C}$ apresentou desempenho superior ao catalisador $\mathrm{Pt}_{75} \mathrm{Sn}_{25} / \mathrm{C}$ da E-TEK indicando que maiores teores de estanho no catalisador levam a maiores valores de corrente em temperaturas mais elevadas, estes resultados indicaram que a existências de óxidos presentes no eletrocatalisador são de extrema importância para auxiliar na eletro-oxidação do álcool e esse efeito tornou-se mais evidente com o aumento da temperatura.

Para a eletro-oxidação de etanol sobre o sistema PtRu observou-se por cronoamperometria que eletrocatalisadores $\mathrm{Pt}_{50} \mathrm{Ru}_{50} / \mathrm{C}$ são mais efetivos para a eletro-oxidação do etanol com relação aos demais eletrocatalisadores 
preparados, tendo o catalisador $\mathrm{Pt}_{50} \mathrm{Ru}_{50} / \mathrm{C}$ E-TEK apresentado maiores valores de corrente a temperatura ambiente. Estes resultados permitem também concluir que para a eletro-oxidação do etanol (que é mais complexa que do metanol) é necessário uma paridade de sítios entre rutênio e platina, esta paridade só seria alcançada para altos teores de rutênio na composição dos eletrocatalisadores. Já os testes em células a combustível unitárias alimentadas diretamente por etanol também mostraram que altos teores de rutênio no catalisador são necessários afim de que se possamos observar melhores desempenhos, e o catalisador $\mathrm{Pt}_{50} \mathrm{Ru}_{50} / \mathrm{C}$ preparado apresentou $\mathrm{O}$ melhor desempenho dentre os sistemas PtRu estudados.

Para a eletro-oxidação do etanol sobre o sistema PtSn observou-se que para os testes eletroquímicos a temperatura ambiente, o catalisador comercial $\mathrm{Pt}_{75} \mathrm{Sn}_{25} / \mathrm{C}$ E-TEK apresentou maiores valores de corrente por cronoamperometria e voltametria cíclica. Entretanto na eletro-oxidação em célula a combustível unitária alimentada diretamente por etanol, biocombustível de grande importância para o Brasil e que vem ganhando cada vez mais espaço no mercado internacional, o catalisador $\mathrm{Pt}_{60} \mathrm{Sn}_{40} / \mathrm{C}$ preparado pelo método do ácido cítrico apresentou o melhor desempenho, obtendo densidade de potência $50 \%$ superior a obtida com o catalisador $\mathrm{Pt}_{75} \mathrm{Sn}_{25} / \mathrm{C}$ HP da E-TEK e cerca de $430 \%$ a mais que a obtida com catalisador Pt/C HP da E-TEK.

Uma comparação dos resultados dos eletrocatalisadores $\mathrm{PtRu} / \mathrm{C}$ e $\mathrm{PtSn} / \mathrm{C}$ preparados pela redução por ácido cítrico em condições otimizadas e reais de operação mostraram que os eletrocatalisadores $\mathrm{PtRu} / \mathrm{C}$ são mais efetivos para a eletro-oxidação do metanol, enquanto que os eletrocatalisadores PtSn/C são mais efetivos para a eletro-oxidação do etanol. 


\section{PROPOSTAS PARA TRABALHOS FUTUROS}

Tem-se a perspectiva da realização futura de alguns experimentos complementares a este trabalho que colaborariam para melhor entendimento dos resultados obtidos, tais como:

i) Realizar experimentos que possam identificar os produtos formados na célula a combustível, com equipamento como o DEMS (Diferencial Electrochimical Mass Spetroscopy), ou com um cromatógrafo acoplado a saída da célula. Alguns testes preliminares já foram realizados em cromatografia gasosa, mas por enquanto as metodologias práticas para coleta de alíquota e análise dos produtos da oxidação de metanol e etanol ainda estão sendo otimizadas.

ii) Estudos da composição da superfície dos catalisadores com técnicas como a do NanoEDX (acoplados em MET) e XPS (X-ray photoelectron spectroscopy), para uma melhor discussão quanto os estados de oxidação e composição das espécies superficiais.

iii) Estudar a possibilidade de se produzir, pelo método de redução do ácido cítrico, eletrocatalisadores ternários e quaternários mais eficientes na eletro-oxidação de metanol e etanol, bem como otimizar as variáveis do método para obtenção destes.

iv) As células DAFC ainda se encontram em estágios de desenvolvimento, por isso um estudo da otimização dos aspectos operacionais como a temperatura, pressão e concentração do combustível, diminuiria o crossover de combustível e melhorariam o rendimento da célula como um todo. No cátodo, a modificação dos catalisadores $\mathrm{Pt} / \mathrm{C}$ por eletrocatalisadores mais estáveis e tolerantes a 
alcoóis aumentariam a eficiência da reação de redução de oxigênio do cátodo, bem como a utilização de placas de grafite de configuração interdigital (ao invés de serpentina) auxiliaria na remoção de condensados aumentando a eficiência da célula.

v) Essas condições permitiriam a realização de experimentos de operação prolongada das células a álcool diretamente com os melhores catalisadores para verificar a estabilidade e quantificar a perda de atividade em função do tempo. 


\section{REFERÊNCIAS BIBLIOGRÁFICAS}

1 WENDT, H.; GÖTZ, M.; LINARDI, M. Tecnologia de Células a Combustível, Química Nova, v. 23, n.4, p. 538-546, 2000.

2 GONZALEZ, E.R. Eletrocatálise e Poluição Ambiental, Química Nova, v.23, p. 262-266, 2000.

3 GOMES NETO, E.H. Evoluir sem Poluir - A Era do Hidrogênio, das Energias Sustentáveis e das Células a Combustível, Curitiba. BrasilH2 Fuel Cell Energy, Ed Autores Paranaenses, 1 ${ }^{a} \mathrm{ed}, 2005,240 p$.

4 TICIANELLI, E.A.; GONZALEZ E.R. Células a combustível: uma alternativa promissora para a geração de eletricidade. Química Nova, v. 12, n.3, p. 268-271, 1989.

5 LINARDI, M.; WENDT, H.; ARICÓ, E. Células a Combustível de Baixa Potência para Aplicações Residenciais, Química Nova, v. 25, p.470-476, 2002.

6 ALDABÓ, R. Célula combustível a hidrogênio: fonte de energia da nova era, São Paulo, Ed. Artliber, 2004, 182 p.

7 LINARDI, M. Hidrogênio e Célula a Combustível. Economia e Energia, v. 66, p. 1-10, 2008.

8 BRAULT, P.; ROUALD`ES, S.; CAILLARD, A.; THOMANN, A.-L.; MATHIAS, J.; DURAND, J.; COUTANCEAU, C.; L'EGER, J.-M.; CHARLES, C.; BOSWELL, R. Solid polymer fuel cell synthesis by low pressure plasmas: a short review. The European Physical Journal Applied Physics, v. 34, p. 151-156, 2006.

9 LAMY, C.; LÉGER, J.-M. Fuel-cells - application to electric vehicles, Journal de Physique IV, v. 4, C1, p. 253, 1994.

10 TICIANELLI, E.A.; GONZALEZ, E.R. Eletroquímica: Princípios e aplicações, São Paulo, EDUSP, 2005, 220p.

11 POZIO, A.; GIORGI, L.; BRACHINI, C.; GIORGI, R.; TURTU, S. $\mathrm{H}_{2}$ and $\mathrm{H}_{2} / \mathrm{CO}$ oxidation mechanism on $\mathrm{Pt} / \mathrm{C}, \mathrm{Ru} / \mathrm{C}$ and $\mathrm{Pt}-\mathrm{Ru} / \mathrm{C}$ electrocatalysts. Journal of Applied Electrochemistry, v. 31, p. 325-334, 2001.

12 LIN, W.F.; IWASITA. T.; VIELSTICH, W. Catalysis of CO electrooxidation at $\mathrm{Pt}, \mathrm{Ru}$, and PtRu alloy. An in situ FTIR study. Journal of Physical Chemistry B, v. 103, p. 3250-3257, 1999. 
13 CAMARA, G.A.; TICIANELLI, E.A.; MUKERJEE, S.; LEE, S.J.; MCBREEN, $J$. The $C O$ poisoning mechanism of the hydrogen oxidation reaction in proton exchange membrane fuel cells. Journal of Electrochemical Society, v. 149, p. 3637-3644, 1998.

14 SANTIAGO, E.I.; TICIANELLI, E.A. The performance of carbon-supported $\mathrm{PtOs}$ electrocatalysts for the hydrogen oxidation in the presence of $\mathrm{CO}$. International Journal of Hydrogen Energy, v. 30, p. 159-165, 2005.

15 SANTIAGO, E.I.; CAMARA, G.A.; TICIANELLI, E.A. CO tolerance on $\mathrm{PtMo} / \mathrm{C}$ electrocatalysts prepared by the formic acid method, Electrochimica Acta, v.48, p. 3527, 2003.

16 LING, J.; SAVADOGO, O. Comparison of Methanol Crossover among Four Types of Nafion Membranes. Journal of the Electrochemical Society, v.151, p. A1604, 2004.

17 BOCK, C.; MacDOUGALL, B.; LePAGE, Y. Dependence of $\mathrm{CH} 3 \mathrm{OH}$ Oxidation Activity for a Wide Range of PtRu Alloys, Journal of Electrochemical Society, v.151, p. A1269, 2004.

18 LONG, J.W.; STROUD, R.M.; SWIDER-LYONS, K.E.; ROLISON, D.R. How to make electrocatalysts more active for direct methanol oxidation - Avoid PtRu bimetallic alloys!, Journal of Physical Chemistry B, v. 104, p. 97729776, 2000.

19 LIZCANO-VALBUENA, W.H.; AZEVEDO, D.C.; GONZALEZ, E.R. Supported metal nanoparticles as electrocatalysts for low-temperature fuel cell. Electrochimica Acta, v. 49, p. 1289-1295, 2004.

20 PETRII, O.A. Pt-Ru electrocatalysts for fuel cells: a representative review, Journal of Solid State Electrochemistry, v.12, p.609-642, 2008.

21 IWASITA, T. Electrocatalysis of methanol oxidation, Electrochim Acta, v. 47, p. 3663-3674, 2002.

22 GUTIERREZ, A.C.; PINHEIRO, A.L.V.; LEIVA, E.; GONZALEZ, E.R.; IWASITA, T. Abnormally fast mobility of $\mathrm{CO}$ at electrochemical interfaces, Electrochemistry Communications, v. 5, p. 539-543, 2003.

23 BATISTA, E.A.; MALPASS, G.R.P.; MOTHEO, A.J.; IWASITA, T. New Insight Into the Pathways of Methanol Oxidation. Electrochemistry Communications, v. 5, p. 843-846, 2003.

24 BATISTA, E. A ; MALPASS, G.R.P.; MOTHEO, A.J.; IWASITA, T. New Mechanistic Aspects of Methanol Oxidation. Journal of Electroanalytical Chemistry, v. 571, p. 273-282, 2004. 
25 BATISTA, E.A.; IWASITA, T. Adsorbed intermediates of formaldehyde oxidation and their role in the reaction mechanism, Langmuir, v. 22, p. 7912-7916, 2006.

26 DE LIMA, R.B.; MASSAFERA, M.P.; BATISTA, E.A.; IWASITA, T. Catalysis of formaldehyde oxidation by electrodeposits of PtRu, Journal of Electroanalytical Chemistry, v. 603, p. 142-148, 2007.

27 LAMY, C.; BELGSIR, E.M.; LÉGER, J.-M. Electrocatalytic oxidation of aliphatic alcohols: Aplication to the direct alcohol fuel cell (DAFC), Journal of Applied Electrochemistry, v.31, p. 799, 2001.

28 MENEZES, T.J.B. Etanol, o combustível do Brasil, São Paulo, Ed. Agronômica Ceres, 1980, 229 p.

29 LAMY, C.; ROUSSEAU, S.; BELGSIR, E.M.; COUTANCEAU, C.; LÉGER, J.-M. Recent progress in the direct ethanol fuel cell: development of new platinum-tin electrocatalysts, Electrochimica Acta, v. 49, p. 3901-3908, 2004.

30 IWASITA, T; PASTOR, E. A dems and FTir spectroscopic investigation of adsorbed ethanol on polycrystalline platinum, Electrochimica Acta, v.39, p.531-537, 1994.

31 CAMARA, G.A.; IWASITA, T. Parallel pathways of ethanol oxidation: the effect of ethanol concentration, Journal of Electroanalytical Chemistry, v.578, p. 315-321, 2005.

32 HITMI, H.; BELGSIR, E. M.; LÉGER, J-M.; LAMY, C.; LEZNA, R. O. A Kinetic, Analysis of the Electrooxidation of Ethanol at a Platinum-Electrode in Acid-Medium. Electrochimica Acta, v.39, p. 407-415, 1994.

33 WENDT, H. Electrochimical Engineering, Science and Technology in Chemical and Other Industries, Springer, 1999.

34 NETO, A.O.; VASCONCELOS, T.R.R.; DA SILVA, R.W.R.V.; LINARDI, M.; SPINACÉ, E.V. Electro-oxidation of ethylene glycol on $\mathrm{PtRu} / \mathrm{C}$ and $\mathrm{PtSn} / \mathrm{C}$ electrocatalysts prepared by alcohol-reduction process. Journal of Applied Electrochemistry, v. 35, p. 193-198, 2005.

35 NETO, A.; FARIAS, L.; DIAS, R.; BRANDALISE, M.; LINARDI, M.; SPINACE, E. Enhanced electro-oxidation of ethanol using $\mathrm{PtSn} / \mathrm{CeO} 2 \mathrm{C}$ electrocatalyst prepared by an alcohol-reduction process. Electrochemistry Communications, p. 1315, 2008.

36 ZHOU, W.; ZHOU, Z.; SONG, S.; LI, W.; SUN, G.; TSIAKARAS, P.; XIN, Q. Pt based anode catalysts for direct ethanol fuel cells. Applied Catalysis B, v. 46, p. 273-285, 2003. 
37 ROUSSEAU, S.; COUTANCEAU, C.; LAMY, C.; L'EGER, J. Direct ethanol fuel cell (DEFC): Electrical performances and reaction products distribution under operating conditions with different platinum-based anodes. Journal of Power Sources, v. 158, p. 18-24, 2006.

38 CARMO, M.; SANTOS, A.R.; SPINACÉ, E.V.; FUESS, H.; POÇO, J.G.R.; LINARDI, M. Alternative supportsfor catalysts preparation for lowtemperature fuel cells using the alcohol reduction method. Studies in Surface Science and Catalysis, v. 162, p. 1009-1016, 2006.

39 WANG, H.; JUSYS, Z.; BEHM, R. Ethanol electro-oxidation on carbonsupported Pt, PtRu and Pt3Sn catalysts: A quantitative DEMS study. Journal of Power Sources, v. 154, p. 351-359, 2006.

40 CAMARA, G.A.; LIMA, R.B.; IWASITA, T. Catalysis of Ethanol Electrooxidation by PtRu. The Influence of Catalyst Composition. Electrochemistry Communications, v. 6, p. 812, 2004.

41 COLMATI, F.; ANTOLINI, E.; GONZALEZ, E. Ethanol oxidation on a carbonsupported Pt75Sn25 electrocatalyst prepared by reduction with formic acid: effect of thermal treatment, Applied Catalysis B, v. 73, p. 106-115, 2007.

42 CARMO, M.; SANTOS, A.R.; POÇO, J.G.R.; LINARDI, M. Physical and electrochemical evaluation of commercial carbon black as electrocatalysts supports for DMFC applications. Journal of Power Sources, v. 173, p. 860866, 2007.

43 JIANG, L.; SUN, G.; ZHOU, Z.; ZHOU, W.; XIN, Q. Preparation and characterization of $\mathrm{PtSn} / \mathrm{C}$ anode electrocatalysts for direct ethanol fuel cell, Catalysis Today, v. 93-95, p. 665-670, 2004.

44 VIGIER, F.; COUTANCEAU, C.; HAHN, F.; BELGSIR, E.; LAMY, C. On the mechanism of ethanol electro-oxidation on Pt and PtSn catalysts: electrochemical and in situ IR reflectance spectroscopy studies. Journal of Electroanalytical Chemistry, v. 563, p. 81-89, 2004.

45 NETO, A.O.; GIZ, M.; PEREZ, J.; TICIANELLI, E.; GONZALEZ, E. The Electro-oxidation of Ethanol on Platinum and Platinum Alloys Supported on High Surface Area Carbon. Journal Electrochemical Society, v. 3, p. A272-A279, 2002.

46 TANAKA, S.; UMEDA, M.; OJIMA, H.; USUI, Y.; KIMURA, O.; UCHIDA, I. Preparation and evaluation of a multi-component catalyst by using a cosputtering system for anodic oxidation of ethanol. Journal of Power Sources, v. 152, p. 34-39, 2005. 
47 SPINACÉ, E. V. ; LINARDI, M.; OLIVEIRA NETO, A. Co-catalytic effect of nickel in the electro-oxidation of ethanol on binary Pt-Sn electrocatalysts. Electrochemistry Communications, v. 7, p. 365-369, 2005.

48 HONMAZ, I.; TODA, T. Temperature Dependence of Kinetics of Methanol Electro-oxidation on PtSn Alloys, Journal of the Electrochemical Society, v.150, p. A1689-A1692, 2003.

49 SPINACÉ, E. V. ; OLIVEIRA NETO, A.; LINARDI, M. Electro-oxidation of methanol and ethanol using PtRu/C electrocatalysts prepared by spontaneous deposition of platinum on carbon-supported ruthenium nanoparticles. Journal of Power Sources, v. 129, p. 121-126, 2004.

50 WATANABE, M.; MOTOO, S. Electrocatalysis by ad-atoms Part II. Enhancement of the oxidation of methanol on platinum by ruthenium adatoms, Journal of Electroanalytical Chemistry, v. 60, p. 267-273, 1975.

51 TICIANELLI, E.; BEERY, J.G.; PAFFETT, M.T.; COTTESFELD, S. An electrochemical, ellipsometric, and surface science investigation of the PtRu bulk alloy surface, Journal of Electroanalytical Chemistry, v. 258, p. 6177, 1989.

52 WASZCZUK, P.; LU, G.-Q.; WIECKOWSKI, A.; LUB, C.; RICE, C.; MASEL, R.I. UHV and electrochemical studies of $\mathrm{CO}$ and methanol adsorbed at platinum/ruthenium surfaces, and reference to fuel cell catalysis, Electrochimica Acta, v. 47, p. 3637-3652, 2002.

53 GAISTEIGER, H.A.; MARKOVIC, N.; ROSS, P.N.; CAIRNS, E.J. Carbon monoxide electrooxidation on well-characterized platinum-ruthenium alloys, Journal of Physical Chemistry, v. 98, p. 617, 1994.

54 KABBABI, A.; FAURE, R.; DURAND, R.; BEDEN, B.; HAHN, F.; LÉGER, JM.; LAMY, C. In situ FTIRS study of the electrocatalytic oxidation of carbon monoxide and methanol at platinum-ruthenium bulk alloy electrodes, Journal of Electroanalytical Chemistry, v.444, p. 41, 1998.

55 CHRZANOWSKI, W.; WIECKOWSKI, A. Surface Structure Effects in Platinum/Ruthenium Methanol Oxidation Electrocatalysis, Langmuir, v. 14, p. 1967, 1998.

56 TONG, Y.Y.; KIM, H.S.; BABU, P.K.; WASZCZUK, P.; WIECKOWSKI, A.; OLDFIELD, E. An NMR Investigation of CO Tolerance in a Pt/Ru Fuel Cell Catalyst, Journal of American Chemical Society, v. 124, p. 468-473, 2002.

57 MORIMOTO, Y.; YEAGER, E.B. CO oxidation on smooth and high area Pt, $\mathrm{Pt}-\mathrm{Ru}$ and Pt-Sn electrodes. Journal of Electroanalytical Chemistry, v. 441 , p. $77-81,1998$. 
58 MORIMOTO, Y.; YEAGER, E.B. Comparison of methanol oxidations on Pt, $\mathrm{Pt}-\mathrm{Ru}$ and Pt-Sn electrodes. Journal of Electroanalytical Chemistry, v. 444, p. 95-100, 1998.

59 WANG, K.; GASTEIGER, H.A.; MARKOVIC, N.M.; ROSS Jr, P.N. On the reaction pathway for methanol and carbon monoxide electrooxidation on PtSn alloy versus Pt-Ru alloy surfaces. Electrochimica Acta, v. 41, p. 25872593, 1996.

60 FRELINK, T.; VISSCHER, W.; COX, A.P.; Van VEEN, J.A.R. Ellipsometry and Dems Study of the Electrooxidation of Methanol at Pt and Ru-Promoted and Sn-Promoted Pt. Electrochimica Acta, v. 40, p. 1537-1543, 1995.

61 STAMENKOVIC, V.R.; MUN, B.S.; ARENZ, M.; MAYRHOFER, K.J.J.; LUCAS, C.A.; WANG, G.; ROSS, P.N.; MARKOVIC, N.M. Trends in electrocatalysis on extended and nanoscale Pt-bimetallic alloy surfaces, Nature Materials, v. 6, p. 241-247, 2007.

62 SPINACÉ, E.V.; OLIVEIRA NETO, A.; FRANCO, E.G.; LINARDI, M.; GONZALEZ, E.R. Métodos de preparação de nanopartículas metálicas suportadas em carbono de alta área superficial, como eletrocatalisadores em células a combustível com membrana trocadora de prótons. Química Nova, v. 27, p. 648-654, 2004.

63 COMISSÃO NACIONAL ENERGIA NUCLEAR. A. Oliveira Neto; M. Linardi; E.V. Spinace; T.R.R. Vasconcelos. Citric acid based preparation of proton exchange membrane fuel cell (PEMFC) electro catalysts comprises dispersion of e.g. platinum nanoparticles in carbon through chemical reduction of metal salts. BR200404730-A, 6 dez. 2005.

64 PILLAI, Z.S.; KAMAT, P.V. What Factors Control the Size and Shape of Silver Nanoparticles in the Citrate Ion Reduction Method?, Journal of Physical Chemistry B, v. 108, p. 945-951, 2004.

65 GUO, J.W.; ZHAO, T.S.; PRABHURAM, J.; CHEN R.; WONG, C.W. Preparation and characterization of a PtRu/C nanocatalyst for direct methanol fuel cells, Electrochimica Acta, v. 51, p. 754-763, 2005.

66 POSTEK, M.T.; HOWARD, K.S.; JOHNSON, A.H.; McMICHAEL, K.L. Scanning Electron Microscopy: A Student's Handbook, Ladd Research Industries Inc., Burlington, 1980, 305p.

67 CULLITY, B.D.; STOCK, S.R. Elements of X-ray diffraction, Upper Saddle River, Prentice Hall, 3aㅡ Ed, 2001, 664 p.

68 WELLER, M.T. Inorganic materials chemistry, Oxford chemistry primers, no $23,1994,92$ p. 
69 KLUG, H. P.; ALEXANDER, L. E. X-ray difraction procedures. For polycrystalline and amorphous materials, New York, Wiley Interscience, $2^{\mathrm{a}}$ ed, 1974, $966 \mathrm{p}$.

70 RADMILOVIĆ, V.; GASTEIGER, H.A.; ROSS Jr, P.N. Structure an Chemical Composition of a Supported Pt-Ru Electrocatalyst for Methanol Oxidation, Journal of Catalysis, v. 154, p. 98-106, 1995.

71 BUSECK, P.R.; COULEY, J.M.; EYRING, L. High-resolution transmission electron microscopy and associated techniques, New York, Oxford Univ. Pr, 1988, 645 p.

72 KESTENBACH , H.J.; BOTTA, W.J. Microscopia eletrônica Transmissão e varredura, São Paulo, ABM, 1989, 104 p.

73 ANDRADE, A.B. Desenvolvimento de conjuntos eletrodo-membranaeletrodo para células a combustível a membrana trocadora de prótons (PEMFC) por impressão à tela. 2008. Dissertação (Mestrado) - Instituto de Pesquisas Energéticas e Nucleares, USP, São Paulo.

74 SILVA, R.W.R.V.; SPINACÉ, E.V.; LINARDI, M.; OLIVEIRA NETO, A. Preparação de eletrocatalisadores $\mathrm{PtRu} / \mathrm{C}$ pelo método de redução por ácido cítrico para aplicação como ânodo na oxidação direta de metanol em células a combustível. Boletim Técnico FATEC-SP, São Paulo, v. 18, p. 62-71, 2005.

75 DU, H.-Y.; WANG, C.-H.; HSU, H.-C.; CHANG, S.-T.; CHEN, U.-S.; YEN, S.C.; CHEN, L.C.; SHIH, H.-C.; CHEN, K.H. Controlled platinum nanoparticles uniformly dispersed on nitrogen-doped carbon nanotubes for methanol oxidation, Diamond \& Related Materials, v. 17, p. 535-541, 2008.

76 COLMATI, F.; LIZCANO-VALBUENA, W.H.; CAMARA, G.A.; TICIANELLI, E.A.; GONZALEZ, E.R. Carbon monoxide oxidation on Pt-Ru electrocatalysts supported on high surface area carbon. Journal of the Brazilian Chemical Society, v. 13, p. 474-482, 2002.

77 ARICO, A.S.; ANTONUCCI, P.L.; MODICA, E.; BAGLIO, V.; KIM, H.; ANTONUCCI, V. Effect of Pt-Ru alloy composition on high-temperature methanol electro-oxidation, Electrochimica Acta, v. 47, p. 3723-3732, 2002.

78 GENG, D.; CHEN, L.; LU, G. pH induced size-selected synthesis of PtRu nanoparticles, their characterization and electrocatalytic properties, Journal of Molecular Catalysis A: Chemical, v. 265, p. 42-49, 2007.

79 GARCIA, G.; BAGLIO, V.; STASSI, A.; PASTOR, E.; ANTONUCCI, V.; ARICOे, A. S. Investigation of Pt-Ru nanoparticle catalysts for low temperature methanol electro-oxidation, Journal of Solid State Electrochemistry, v. 11, p. 1229-1238, 2007. 
80 WANG, M.; GUO, H.; MA, C. Dynamic Characteristics of a Direct Methanol Fuel Cell, Journal of Fuel Cell Science and Technology, v. 3, p. 202-207, 2006.

81 THOMAS, S.C.; REN, X.; GOTTESFELD, S.; ZELENAY, P. Direct methanol fuel cells: progress in cell performance and cathode research, Electrochimica Acta, v. 47, p. 3741-3748, 2002.

82 GASTEIGER, H.A.; MARKOVIC, N.; ROSS, P.N.; CAIRNS, E.J. Methanol electrooxidation on well-characterized platinum-ruthenium bulk alloys, Journal of Physical Chemistry, v.97, p. 12020, 1993.

83 GASTEIGER, H.A.; MARKOVIC, N.; ROSS, P.N.; CAIRNS, E.J. Electrooxidation of small organic molecules on well-characterized Pt-Ru alloys, Electrochimica Acta, V. 39, p.1825-1832, 1994.

84 BAGLIO, V.; ARICO, A.S.; DI BLASI, A.; ANTONUCCI, P. L.; NANNETTI, F.; TRICOLI, V.; ANTONUCCI, V. Zeolite-based composite membranes for high temperature direct methanol fuel cells, Journal of Applied Electrochemistry, v. 35, p. 207-212, 2005.

85 BAUER, A.; GYENGE, E.L.; OLOMAN, C.W. Direct methanol fuel cell with extended reaction zone anode: PtRu and PtRuMo supported on graphite felt, Journal of Power Sources, v. 167, p. 281-287, 2007.

86 SONG, S.; ZHOU, W.; LIANG, Z.; CAI, R.; SUN, G.; XIN, Q.; STERGIOPOULOS, V.; TSIAKARAS, P. The effect of methanol and ethanol cross-over on the performance of PtRu/C-based anode DAFCs, Applied Catalysis B, v. 55, p. 65-72, 2005.

87 RADMILOVIĆ, V.; RICHARDSON, T.J.; CHEN, S.J.; ROSS Jr., P.N. Carbon-supported Pt-Sn electrocatalysts for the anodic oxidation of $\mathrm{H}_{2}, \mathrm{CO}$, and $\mathrm{H}_{2} / \mathrm{CO}$ mixtures. Part I. Microstructural characterization, Journal of Catalysis, v. 232, p. 199-209, 2005.

88 JIANG, L.; SUN, G.; ZHOU, Z.; SUN, S.; WANG, Q.; YAN, S.; LI, H.; TIAN, J.; GUO, J.; ZHOU, B.; XIN. Q. Size-Controllable Synthesis of Monodispersed SnO2 Nanoparticles and Application in Electrocatalysts, Journal of Physical Chemistry B, v. 109, p. 8774-8778, 2005.

89 COLMATI, F.; ANTOLINI, E.; GONZALEZ, E.R. Effect of thermal treatment on phase composition and ethanol oxidation activity of a carbon supported Pt50Sn50 alloy catalyst, Journal of Solid State Electrochemistry, v. 12, p. 591-599, 2008.

90 SONG, S.Q.; ZHOU, W.J.; LI, W.Z.; SUN, G.; XIN, Q.; KONTOU, S.; TSIAKARAS, P. Direct Methanol Fuel Cells : Methanol Crossover and its Influence on Single DMFC Performance, Ionics, v. 10, p. 458-462, 2004. 
91 ZHOU, W.J.; SONG, S.Q.; LI, W.Z.; SUN, G.Q.; XIN, Q.; KONTOU, S.; POULIANITIS, K.; TSIAKARAS, P. Pt-based anode catalysts for direct ethanol fuel cells, Solid State Ionics, v. 175, p. 797-803, 2004.

92 OLIVEIRA NETO, A.; DIAS, R.R.; TUSI, M.M.; LINARDI, M.; SPINACE, E.V. Electro-oxidation of methanol and ethanol using PtRu/C, PtSn/C and $\mathrm{PtSnRu} / \mathrm{C}$ electrocatalysts prepared by an alcohol-reduction process, Journal of Power Sources, 166, p. 87-91, 2007.

93 JIANG, L.; SUN, G.; SUN, S.; LIU, J.; TANG, S.; LI, H.; ZHOU, B.; XIN, Q. Structure and chemical composition of supported Pt-Sn electrocatalysts for ethanol oxidation, Electrochimica Acta, v.50, p. 5384-5389, 2005.

94 KORDESCH , K.; SIMADER, G. Fuel cells and their applications, Weinheim, VCH, 1996, $375 \mathrm{p}$.

95 JIANG, L.; ZANG, H.; SUN, G.; XIN, Q. Influence of Preparation Method on the Performance of PtSn/C Anode Electrocatalyst for Direct Ethanol Fuel Cells, Chinese Journal of Catalysis, v. 27, p. 15-19, 2006.

96 ZHOU, W.J.; SONG, S.Q.; LI, W.Z.; ZHOU, Z.H.; SUN, G.Q.; XIN, Q.; DOUVARTZIDES, S.; TSIAKARAS, P. Direct ethanol fuel cells based on PtSn anodes: the effect of Sn content on the fuel cell performance, Journal of Power Sources, v.140, p.50, 2005. 